\title{
Polychaeta, Annelida, and Articulata are not monophyletic: articulating the Metameria (Metazoa, Coelomata)
}

\author{
Waltécio de Oliveira Almeida 1, Martin Lindsey Christoffersen 1, Dalton de Souza Amorim ${ }^{2}$, \\ André Rinaldo Senna Garraffoni ${ }^{3} \&$ Gustavo Sene Silva ${ }^{3}$
}

\author{
${ }^{1}$ Departamento de Sistemática e Ecologia, Universidade Federal da Paraíba. 58051-900 João Pessoa, Paraíba, Brasil. \\ Respective e-mails: woalmeida@hotmail.com and mlchrist@dse.ufpb.br \\ ${ }^{2}$ Departamento de Biologia, Faculdade de Filosofia, Ciências e Letras de Ribeirão Preto, Universidade de São Paulo. \\ 14040-901 Ribeirão Preto, São Paulo,Brasil. E-mail: dsamorim@usp.br \\ ${ }^{3}$ Centro de Estudos do Mar, Universidade Federal do Paraná. 83255-000 Pontal do Paraná, Paraná, Brasil. \\ Respective e-mails: agarraffoni@lycos.com and gsene@lycos.com
}

\begin{abstract}
Polychaetes are metameric worms recognized for having parapodia, chaetae, and nuchal organs. Some authors have extended the Annelida to include Pogonophora, Echiura, and Clitellata. These suggestions are insufficient to generate a monophyletic group. They do not take into account two very large and important clades that in a cladistic analysis at a higher level are shown to be nested within the Annelida: the Ecdysozoa (arthropods and related taxa) and Enterocoela (deuterostomes and related taxa). Evolutionary histories of most characters across metazoan phyla are still very poorly known. Metameres and coeloms have been considered homoplastic in the literature, and yet the homeobox genes responsible for the expression of metamerism and of paired appendages, at least, are very largely distributed among the Metazoa. A phylogenetic analysis was performed for the ingroups of Polychaeta, including Clitellata, Enterocoela, and Ecdysozoa as terminal taxa. The remaining non-metameric phyla Platyhelminthes, Nemertea, Mollusca, and Sipuncula were included to root the tree within the Bilateria. Empirical data was obtained from the literature and run with the software Hennig86 with two comparative interpretations of a priori hypotheses of primary homology: one with negative characters (coding losses) and another considering only positive characters (without assumptions about losses). The most relevant conclusions are: (1) Annelida and Polychaeta are non-monophyletic, even when including Echiura, Clitellata, and Pogonophora; (2) Articulata, as traditionally circumscribed for Annelida and Arthropoda, is also not monophyletic; (3) Metameria becomes monophyletic only when Ecdysozoa and Enterocoela are included in addition to the traditional annelid taxa; (4) Ecdysozoa are the sister group of Aphrodita; (5) Clitellata are related to depositfeeding sedentary polychaetes (scolecids), and Questidae represent their sister group; (6) Owenia plus Enterocoela form a monophyletic group related to the tubicolous polychaetes.
\end{abstract}

KEY WORDS. Bilateria, Clitellata, Ecdysozoa, Enterocoela, Metazoa, phylogeny, Polychaeta.

The phylogenetic history of the polychaetes is long and diverse. The first efforts may be characterized as strictly taxonomical. Various authors have differed in the emphases given to the importance of general body shape and feeding habits, some attention being provided to the anatomy of particular structures (Linnaeus 1758; Lamarck 1801; Cuvier 1816; Blainville 1816; Audouin \& Milne Edwards 1832; Grube 1850; Quatrefages 1866). The first evolutionary proposal for the group is that of HATSCHEK $(1878,1893)$. He expounds a progressive view, which starts with the simpler archiannelids.

More recently, Dales $(1962,1963)$ contributed with evolutionary considerations based on the structure of the pharynx. The system is rather conservative and maintains the general lines of Натsснек $(1878,1893)$, with archiannelids at the base. Clark $(1963,1964)$ innovated considerably by interpreting the origin of segmentation as an adaptation for excavation. He proposed an oligochaetoid basic plan and contested either the unity or the basal position of the archiannelids. Hermans (1969), Orrhage (1974), Trueman (1975), Alós (1982), PurschKe (1985a, b, 1987a, b, 1988a), and PunschKe $\&$ Jouin (1988) have corroborated this latter point.

Mileikovsky $(1968,1977)$ proposed a new classification of the Polychaeta Grube, 1850 based largely on larval traits. In it he incorporated some of the ideas of Dales $(1962,1963)$. 
STORCH (1968) introduced further changes. After analyzing the muscular pattern of several polychaetes, he pointed to an aphroditid-like groundplan for the group. This was contrary to Clark $(1963,1964)$, who maintained a simple groundplan without locomotory or sensory appendages. Polychaete families continued to be treated as natural units without any detectable interrelationships by Hartman (1968, 1969). Меттам (1971) reexamined the muscular ultrastructure of Aphrodita aculeata Linnaeus, 1761 and concluded that this taxon was specialized, contrary to SтоRсн's (1968) position.

Fauchald $(1974,1977)$ proposed non-arbitrary family relationships for the first time. He positioned some of the scolecids, such as Capitellidae Grube, 1862, Orbiniidae Hartman, 1942 and Questidae Hartman, 1966, at the base of his system. Pilato (1981) resurrected Storch's (1968) ideas on the primitiveness of the errant polychaetes and suggested that they could be derived directly from a flatworm-like ancestor.

Christoffersen \& Araújo-de-Almeida (1994) first proposed the paraphyletic nature of the polychaetes. They indicated that Enterocoela Huxley, 1875 (Pogonophora Ivanov, 1949, the lophophororates, and Deuterostomia Huxley, 1875) would be the sister group of part of the Polychaeta, most probably of the Oweniidae Rioja, 1917. Nielsen (1995) also interpreted Polychaeta as paraphyletic, but suggesting that Pogonophora, Echiura Newby, 1940, Lobatocerebridae Rieger, 1980, Gnathostomulida Ax, 1956, and Sipuncula Sedgwick, 1898 also belong to this taxon.

Rouse \& FAuchald (1995) argued for the monophyly of the Polychaeta. The presence of nuchal organs was chosen as their main autapomorphy. They questioned the validity of the Annelida Lamarck, 1801, but EibYe-JACOBSEN \& NielSEN (1996) did not agree. The latter authors argument that the inclusion of groups such as Clitellata Michaelsen, 1928 and Pogonophora should be made a priori. Otherwise Polychaeta would become paraphyletic. However, Rouse (1997) criticized the supposedly unnecessary and non-parsimonious assumptions that such a procedure would entail. He suggested that it might be preferable to analyze paraphyletic groups than to arbitrarily include questionable taxa such as Pogonophora into the analysis, regardless of whether the final results ended with more or fewer steps.

Westheide (1997) questioned the validity of the Polychaeta, discussing different possibilities for the origin of segmentation and parapodia. He argued that Clitellata is an ingroup of the Polychaeta and indicated a probable homology of parapodia and arthropod legs. Rouse \& Fauchald (1997) published a detailed phylogeny of the families of polychaetes, with an extensive discussion of characters. The evidence for the monophyly of some terminal taxa was inconclusive.

PunschKe (1997) demonstrated that nuchal organs are absent in several polychaetes specialized for a terrestrial way of life (e.g., Hrabeiella periglandulata Pizl \& Chalupský, 1984, Parergodrilus heideri Reisinger, 1925, and Stygocapitella subterranea Knöllner, 1934). He speculated that a similar adaptation may have occurred in the Clitellata.

McHugh (1997) did not accept the monophyletic status of the Polychaeta. Her molecular data indicated that Echiura belongs to this group. Furthermore, she dissented from Rouse \& Fauchald (1997) by placing Harmothoe Kinberg, 1855 and Nereis Linnaeus, 1758 near the base of the cladogram, and by producing phylogenetic trees that are distinctly incongruent from those of the latter authors in several details. SIDDAL et al. (1998) suggested that the data used by McHugH (1997) were insufficient to decide the position of Echiura and Pogonophora, and thus inadequate as a basis to reclassify the Annelida. This criticism has been vigorously rebutted by McHugH (1999).

Kojima (1998) used molecular data to position the Clitellata among the polychaetes. Once again, the molecular results were totally incongruent with those obtained from morphology by Rouse \& FauchaLd (1997).

Giangrande \& Gambi (1998) developed a hypothesis for the origin of the Polychaeta that is similar to that of HATSCHEK $(1878,1893)$. They considered both the presences of a standard trochophore larva and the post-larval development in the archiannelid Polygordius Schneider, 1868 as possible indications of primitiveness. Consequently, they interpreted the polychaete ancestor as being interstitial and polygordiid-like, from which all the remaining polychaetes would have been derived.

Rouse \& Fauchald (1998) revised the heuristic value of their previous cladistic results (Rouse \& Fauchald 1995, 1997). They concluded that the alternative proposals of WESTHEIDE (1997), McHugh (1997), Purschke (1997), and Giangrande \& GAMBI (1998) required an additional set of aprioristic assertions that exceeded the present knowledge available for the Polychaeta and Annelida. These conclusions have been reaffirmed in the synthesis of WeSTHEIDE et al. (1999).

Although Rouse \& Fauchald (1998) and Rouse (in WESTHEIDE et al. 1999) persist in defending the monophyly of the Polychaeta, new contrary evidence was presented by HessLing \& Westheide (1999). These authors argued that the development of the supraoesophageal ganglion of Enchytraeus crypticus Westheide \& Graefe, 1992 clearly demonstrated that the Clitellata were derived from a polychaetoid pattern and did not represent a primitive condition as predicted by the cladistic hypothesis of Rouse \& Fauchald $(1995,1997)$.

PurschKe (1999) investigated several further adaptive apomorphies occurring in the specialized terrestrial polychaetes (Hrabeiella periglandulata, Parergodrilus heideri and Stygocapitella subterranea). These adaptive traits included the simplification or loss of prostomial appendages, parapodia, and nuchal organs. Further similarities between the terrestrial polychaetes and the clitellates were encountered in the supraoesophageal ganglion, development patterns, and reproductive strategies.

BRown et al. (1999) provide new molecular data from histone H3, U2 snRNA, and 28S rDNA in support of the inclusion of Echiura, Pogonophora, and Clitellata within the Polychaeta. As with McHugh (1997) and KoJIMA (1998), several of their proposed clades are incongruent with those suggested by Rouse \& Fauchald (1997).

A phylogenetic revision of the errant polychaetes led Almeida \& Christoffersen (2000) to argue once more for the paraphyly of the Polychaeta. MANTON (1967) produced the main tentative arguments against considering the parapodia of polychaetes homologous to the lobopodia and arthropodia of the Onychophora Guilding, 1826 and Arthropoda Siebold, 1848, respectively. Almeida \& ChristofFersen $(2000)$ argumented that the musculature of Aphrodita Linnaeus, 1758 is already quite advanced for walking on the substrate and thus pinpointed Aphrodita as the most likely sister group of Arthropoda and related groups. This enhances the problem of the paraphyly of the Polychaeta by requiring the interpretation that the Ecdysozoa Aguinaldo, Turbeville, Linford, Rivera, 
Garey, Raff \& Lake, 1997 represent an "annelid specialization" (Almeida \& Christoffersen 2000).

More recently McHugh (2000) reviewed the molecular data pertaining to annelid phylogeny. Annelida and Polychaeta were reaffirmed to be non-monophyletic because of the exclusion of Echiura, Pogonophora, and Clitellata. These groups are probably modified from polychaetes.

The contribution provided in this paper is twofold. First, the Ecdysozoa, Enterocoela, and Clitellata are placed together with their closest relatives among the polychaetes. Second, a number of characters that have been insufficiently considered up to this date are discussed under a phylogenetic perspective. As a result, some novel transformation series are suggested. Moreover, it is hoped that some of the present hypotheses of homology of different structures proposed herein will have the potential to change the consensual, old views on metazoan phylogeny in a significant way.

\section{MATERIAL AND METHODS}

The literature was used as the main source of empirical data in this work. Therefore the results should be considered preliminary and dependent on future anatomical and molecular studies for corroboration of the present hypotheses of homology. However, this work is not alone in using descriptive data in the literature as a logical first step for producing broad phylogenies. For example, Schram (1991) and Rouse \& Fauchald $(1995,1997)$, among others, present results that are broadly accepted or actively debated by the scientific community.

The analyses included most families of Polychaeta and the basal groups of Ecdysozoa (including Acanthocephala Koelreuter, 1771, Arthropoda Siebold, 1848, Gastrotricha Metschnikoff, 1864, Gnasthostomulida Ax, 1956, Kinorhyncha Reinhard, 1887, Loricifera Kristensen, 1983, Nematoda Rudolphi, 1793, and Nematomorpha Vejdovsky, 1886, Onychophora Guilding, 1826, Pentastomida Rudolphi, 1819, Priapulida Delage \& Herouard, 1897, Rotifera Cuvier, 1798, and Tardigrada Spallanzani, 1776) (SCHMidt-RhaEsa et al. 1998; Almeida \& Christoffersen 2000: 19-21). Many lobopodian fossils were considered as belonging to a more basal position in relation to the arthropod lineage (Monge-Nájera 1995; MongeNájera \& Hou 1999).

Characters of the Enterocoela Huxley, 1875 (including Brachiopoda Cuvier, 1802, Cephalochordata Owen, 1846, Cephalodiscida Fowler, 1892, Chaetognatha Huxley, 1875, Echinodermata Klein, 1734, Ectoprocta Nitsche, 1869, Enteropneusta Huxley, 1875, Phoronida Wright, 1856, Pogonophora Ivanov, 1949, Rhabdopleurida Schmiketsch, 1890, Tunicata Lamarck, 1815, and Vertebrata Cuvier, 1817) are based on Christoffersen \& Araújo-De-Almeida (1994). The procedures described in Christoffersen \& Araújo-De-Almeida (1994) were followed for organizing and analyzing the available descriptive information.

The main emphasis in this paper has been to provide a general framework at the higher levels of generality of the Metameria Christoffersen \& Araújo-de-Almeida, 1994, in order to reduce excessive convergence perceived in the traditional schemes of metazoan phylogeny. For this reason, like Rouse \& FAUCHALD (1997), several interstitial, commensal, parasitic, and pelagic groups were not included in analyses: Aberrantidae
Wolf, 1987, Aelosomatidae Beddard, 1895, Alciopidae Ehlers, 1864, Ctenodrilidae Kennel, 1882, Diurodrilidae Kristensen \& Niilonen, 1982, Fauveliopsidae Hartman, 1971, Hartmaniellidae Imajima, 1977, Histriobdellidae Vaillant, 1890, Ichthyotomidae Eisig, 1906, Iospillidae Bergström, 1914, Lopadorhynchidae Claparède, 1868, Myzostomidae Benham, 1896, Nautillienellidae Miura \& Laubier, 1990, Nerillidae Levinsen, 1883, Oenonidae Kinberg, 1865, Parergodrilidae Reisinger, 1925, Poeobiidae Heath, 1930, Polygordiidae Czerniavsky, 1881, Pontodoridae Bergström, 1914, Potamodrilidae Bunke, 1967, Protodrilidae Czerniavsky, 1881, Protodriloidea Purschke \& Jouin, 1988, Psammodrilidae Swedmark, 1952, Saccocirridae Czerniavsky, 1881, Sternaspidae Carus, 1863, Spintheridae Johnston, 1865, Tomopteridae Johnston, 1865, Typhloscolecidae Uljanin, 1878, and Uncispionidae Green, 1982. These groups are assumed to be highly derived, yet closely related to the taxa included in the analyses, but their exact positions are beyond the purpose of this paper.

Another taxon not included in these analyses was the Echiura. Similarly to the above taxa, they may be highly modified polychaetes. The resolution of their phylogenetic position demands analyses at much lower levels of generality than has been possible to deal with herein.

Chrysopetalidae Ehlers, 1864 and Hesionidae Grube, 1850 were also excluded from our analyses because the monophyly of the first taxon is uncertain (Almeida \& Christoffersen 2000), considering that the analyses of Plejjel \& DAHLGREN (1998) is still insufficient to resolve the position of the Chrysopetalidae.

Finally, Sphaerodoridae Malmgren, 1867 and Lumbrineridae Schmarda, 1861 were not mentioned in this paper, because there is a possibility that these taxa represent internal groups of Syllidae Grube, 1850 and Eunicidae Berthold, 1827, respectively (Almeida \& CHRISTOFFERSEN 2000).

The cladistic analyses were based on Hennigian principles (Hennig 1966; Wiley 1981; Wägele 1994, 1995, 1996a, b, 1999; AмоRIM 2002). For phylogenetic reconstructions we used the program Hennig86 version 1.5 (FARRIS 1989). The commands "ie*" was used in order to obtain all parsimonious trees. When the number of trees obtained was larger than 100, " $\mathrm{x} \mathrm{sw"} \mathrm{was}$ used for successive weighting. The most parsimonious trees obtained from the best characters, as indicated by their "ri", and "ne", where then used to construct strict consensus trees. As a screen interface to construct the data matrix and to better visualize the resultant trees in Windows, the program TreeGardener v. 2.2 was used (RAmos 1996).

To polarize characters the method of comparison with multiple outgroups was used (NIXON \& CARPENTER 1993; CHRISTOFfersen \& Araújo-De-Almeida 1994; Moura \& Christoffersen 1996; AMORIM 2002; von Sternberg 1997). Flatworms, nemerteans, molluscs and sipunculids were selected as outgroups.

One of the most difficult tasks in an analysis is to obtain a matrix with good characters (АмоRIM 2002). This means making correct hypotheses of primary homology, establishing adequate subdivisions between different character states, deciding upon an appropriate order for these states, verifying their occurrences in different terminal taxa, and inferring their presence in stem-lineages. In short, it does not seem very sensible to perform numerical analysis of provisional matrices (Wägele 1994, 1996a, 1999; Mikkelsen 1998). To avoid these problems, characters were grouped into general systems, 
ordered so as to form biologically interdependent transformation series of character states whenever possible. For example, it has been recognized that, in a single transformation series of primary homology, larvae are originally trochophorelike, then become gradually tornaria-like, and finally become lost in several specialized lineages when development has become direct. This procedure is very different from simply coding different larval types as typologically distinct characters (which results in different tree topologies). To minimize cases of "pseudoplesiomorphy" (WILEY 1981), two alternative coding strategies were adopted. In the "negative series", following the criteria of MikKelsen (1998) and PuRSChKe et al. (2000), absences for which there are clear evidences of secondary reductions were considered as further valid character states. Cases in which it can be shown that there is structure reduction (because of marks, sutures, or whatever positive evidences) cannot be coded as absences (coded as zeros). In the "positive series", characters have not been coded as losses. Both coding strategies have been analyzed as non-ordered and as ordered transformations. The results of the four independent analyses were then compared.

Despite this particular treatment of special characters, the use of explicit subjectivity as methodologically adequate is not advocated. Being objective does not mean closing ones eyes for subtle evidences of secondary reductions (see PURSCHKE et al. 2000). Such oversights frequently result in the misplacement of apical taxa to basal positions. Problems of primary homology, ordering, and coding may nevertheless still affect the interpretation of some characters. Such errors are intensified by the fact that comprehension of the evolution of some structures, such as nephridia and larvae (see BARTOLOMAEUS \& Ax 1992; Rouse \& Fauchald 1997; Rouse 1999), among many others, must still be considered fragmentary. Evolutionary changes in the biology of many groups may dramatically affect them in parallel ways. For example, colonization of terrestrial environments has occurred in some specialized polychaetes, such as Hrabeiella periglandulata, and the clitellates (PurschKe 1999; Hessling \& Westheide 1999; PunschKe et al. 2000).

Several noisy characters, still cursorily described in the literature or of uncertain phylogenetic content (e.g., number of eyes, number of segments, length of animal, ultrastructural features of sperm, etc.) were not utilized in the analyses in order to preserve the stronger phylogenetic signal provided by the more congruent data. This certainly affects the overall result, since it impoverishes a matrix that desperately needs more reliable data.

\section{RESULTS}

During the analyses, closely related family-level taxa (of uncertain monophyletic status) were grouped into larger terminal groups: Sigalionoidea (including Pholoidae Kinberg, 1858, and Sigalionidae Malmgren, 1867), Polynoidea (including Acoetidae Kinberg, 1856, Eulepethidae Chamberlin, 1919, Polynoidae Malmgren, 1867, and part of the Aphroditidae Malmgren, 1867), Spionida (including Apistobranchidae Mesnil \& Caullery, 1898, Chaetopteridae Audouin \& Milne Edwards, 1833, Longosomatidae Hartman, 1944, Magelonidae Cunningham \& Ramage, 1888, Poecilochaetidae Hannerz, 1956, Spionidae Grube, 1850, and Trochochaetidae Pettibone, 1963), Terebellida (including Acrocirridae Banse, 1969, Alvinellidae Desbruyères \& Laubier, 1986, Ampharetidae Malmgren, 1866,
Cirratulidae Carus, 1863, Flabelligeridae Saint-Joseph, 1894, Pectinaridae Quatrefages, 1866, Terebellidae Malmgren, 1867, and Trichobranchidae Malmgren, 1866), Sabellida (including Sabellariidae Johnston, 1865, Sabellidae Malmgren, 1867, Serpulidae Johnston, 1865, and part of the Owenidae Rioja, 1917) and Paraonida (including Cossuridae Day, 1963, Orbiniidae Hartman, 1942, Paraonidae Cerruti, 1909, and Scalibregmatidae Malmgren, 1867). Although these groupings do not always represent the most widely accepted taxa in polychaete taxonomy, these groups were chosen in order to reduce to a minimum the potential influence of paraphyletic taxa in the analyses. Nevertheless, Sigalionoidea, Polynoidea, Spionida, and Paraonida remain paraphyletic. The ingroup resolution of these terminals is not the scope of this work, which aims to provide a general framework for the higher levels of generality of the metameric metazoans.

The 60 characters used in our analyses are presented in tables I-III. A total of 34 of these characters were marked as uncertain ("?") for Ecdysozoa. This coding is a result of the use of the fossil Cambrian lobopodians as the basal group of Ecdysozoa. This choice strongly influences the positioning of the Ecdysozoa in our analyses. Nevertheless, this position was maintained, because any other form of coding the characters (for example, as primary absences or secondary losses) would also significantly affect the results of the analyses, either by excluding the Ecdysozoa from the polychaetes, or by attracting them to more specialized branches such as the Clitellata. The evolutionary transitions necessary for either of these two latter hypotheses could only have occurred by way of the fossil lobopodians. The Recent onychophorans are morphologically too distant from the Cambrian fossils, and their adaptations for the terrestrial environment may significantly obscure their ancestral morphology and anatomy. By opting for a middlegroud-solution it is hoped that the large number of question marks will serve to instigate future research, which may corroborate or refute the results.

The positive series were analyzed as ordered, two trees being obtained (length 129 , ci 0.65 , and ri 0.88 ), the consensus of which is presented in figure $1 \mathrm{a}$. The unordered analysis of the proposed transformation series resulted in 1575 trees (length 114 , ci 0.73 , and ri 0.90). The successive weighting option was used and the number of trees obtained was reduced to 310 (length 784 , ci 0.88 , and ri 0.96), the consensus of which is presented in figure $1 \mathrm{~b}$.

The ordered negative series resulted in three parsimonious trees (length 128, ci 0.78, and ri 0.94) (Fig. 2a). The unordered negative series resulted in 330 parsimonious trees (length 121 , ci 0.83 , and ri 0.93 ), which were reduced to 120 trees (length 946, ci 0.91, ri 0.97) by successive weighting (Fig. 2a).

The main differences among these analyses are that the positive series resulted in more parsimonious cladograms, while the negative and ordered analyses produced the most resolved topologies.

Much more significantly than the differences, however, is that all four analyses are congruent in indicating that the Polychaeta become monophyletic only when Ecdysozoa, Clitellata, and Enterocoela are included among the remaining taxa of metameric worms. The clades Aphrodita + Ecdysozoa (Holopodia, tax. nov.), Questidae + Clitellata (Apoclitellata, tax. nov.), and Owenia + Enterocoela (Neotrochozoa, tax. nov.) are maintained throughout our analyses. 

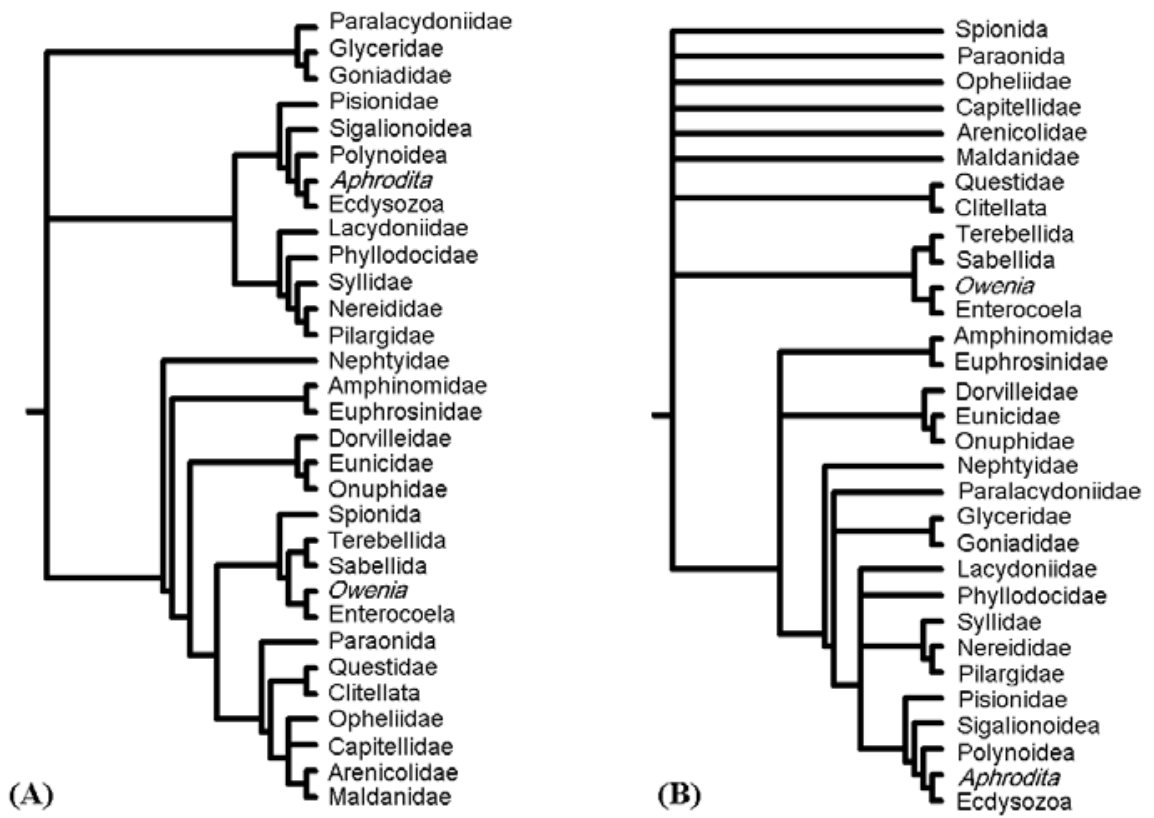

Figure 1. (A) Strict consensus tree (length 129 , ci 0.65 , ri 0.88 ) of the 2 trees obtained from analysis of the positive ordered series. (B) Consensus tree (lenght 910, ci 0.76 , ri 0.90 ) of the 310 trees obtained with successive weighting from our analysis of our positive unordered series.
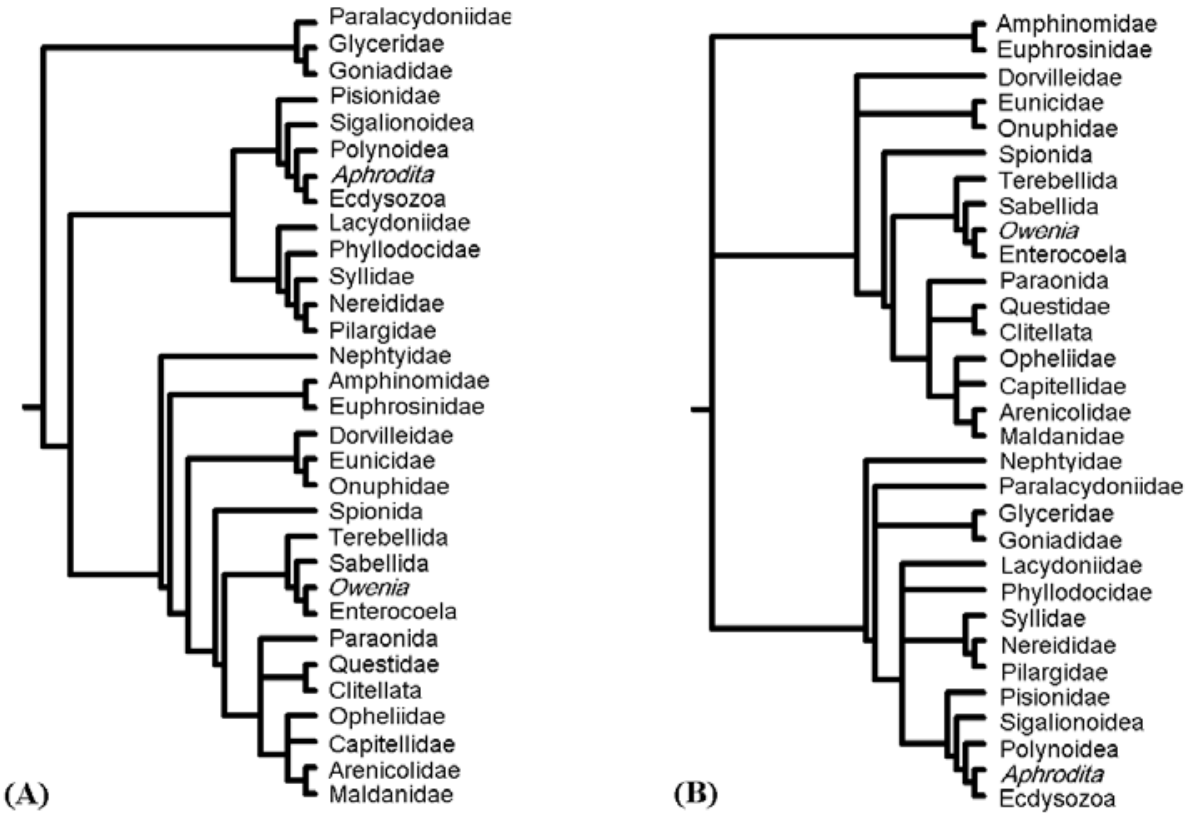

Figure 2. (A) Strict consensus (Length 128 , ci 0.83 , ri 0.93) of the 3 trees obtained from the analysis of ordered negative series. (B) Strict consensus tree (length 963 , ci 0.90 , ri 0.96 ) of the 120 trees obtained with successive weighting from analysis of negative unordered series. 


\section{DISCUSSION}

\section{About hypotheses of homologies and phylogenetic relationships}

The following discussion presents hypotheses of primary homology based on the totality of the results. As in any cladistic analysis, it is evident that hypotheses of primary homology influence the results. However, all hypotheses of relationships presented below were a product of the cladograms. The two most polemical results refer to the positions of the Ecdysozoa and of the Enterocoela among the polychaetes. These ideas have received a high degree of $a$ priori rejection and have generated strong opposition among many researchers.

Much empirical support for the inclusion of Ecdysozoa and Enterocola among the polychaetes is presented below (synapomorphies \#23(2), \#24(2), \#35, \#44(2), \#52, \#59, \#60; Tab. I). Independent empirical data derived from Hox genes represent the most surprising discovery of recent molecular studies. Much of the genetic machinary that patterns the appendages of polychaetes, arthropods, and vertebrates is homologous (Shubin et al. 1997; Panganiban et al. 1997). Furthermore, it has been amply demonstrated that the homologous Hox genes are responsible for the definition of the dorso-ventral and anterior-posterior body axes, and for segmentation in polychaetes, arthropods and vertebrates (McGinnis et al. 1984; Lawrence 1990; François \& Bier 1995; Holley et al. 1995; Jones \& SMith 1995; Holland et al. 1997). New developmental data on Hox genes further indicates not only that deuterostomes derive from a protostome ancestor, but also that a polarity inversion of both body axes has occurred in this process (Nübler-Jung \& ARENDt 1994; 1999; ArendT \& NÜBLER-JUNG 1994, 1997, 1999).

Consequently, the hypotheses presented below reinforce the idea that some scale worms have become armored and that, in the case of Aphrodita, their parapodia have developed functionally and anatomically to a condition approaching the lobopodia. On the other hand, there are other polychaetes such as Owenia that "mysteriously" present deuterostome conditions in their larvae and during embryonic development.

Must all these coincidences be explained away as the result of developmental constraints (see SOMMER 1999)? Even admitting the possibility of a positive response to this question, Aphrodita, Questidae and Owenia still serve as models for understanding how Ecdysozoa, Clitellata and Enterocoela may realistically have evolved from segmented vermiform ancestors. Under this perspective it is no longer necessary to create "imaginary ancestors", such as the hemocoelomate worms of VALENTINe (1989), ERwin et al. (1997), and Fryer $(1996,1998)$, or even non-existent structures such as the antenniform appendage of PANGaniban et al. (1997).

\section{Characters}

\section{Mollusk-like cleavage}

Mollusca and Sipuncula share a peculiar pattern of cleavage, in which the cross-shaped center of the apical end of the embryo is formed by blastomeres $1 \mathrm{a}^{12}-1 \mathrm{~d}^{12}$ (see Scheltema 1993) (Tab. 1, \#1). Rouse \& FAUCHALD (1995) also used this character, but SALVINI-PLAWEN (1988) strongly objected to the validity of this supposed synapomorphy of Mollusca+Sipuncula. There is uncertainty about the validity of this character and of the validity of the clade Mollusca+Sipuncula, but the character was included in the analyses to provide some data for the resolution of the multiple outgroups. An equally parsimonious interpretation for this character would be to consider the shared condition of Mollusca + Sipuncula symplesiomorphic in relation to a modified cross in the Annelida.

\section{Homologies related to coeloms and metameres}

Wägele et al. (1999) note that the reduction of the annelid-like hydrostatic coelom is possible in Arthropoda because when segmental appendages develop into effective legs the hydraulic pressure needed for peristaltic movements become superfluous (this reasoning is also valid for noneuarthropods such as Onychophora). Actually, as Almeida \& CHRISTOFFERSEN (2000) have shown, the coelom condition of Aphroditidae (with reduced peritomium septae) is intermediary between that of typical errant polychaetes and that of onychophorans, as is also the case of the locomotory system.

Coelom development in Metameria (Tab. I, \#2) is closely linked to a gradual production of metameres (compartmented segments are associated with a ganglioned nervous system (Tab. I, \#3). The aschelminths also present evidences of metamerism, particularly in some clades (e.g., ganglioned nervous system of the Rotifera and Kinoryncha) (see Almeida \& Christoffersen 2000: fig. 2, tab. 2). The recognition of these metameres has been underscored in the literature due to an emphasis on the so-called "typical" (usually parasitic) representatives of each group. In the highly modified forms for a parasitic or interstitial way of life, the metameric organization becomes less conspicuous.

Traditionally, theories about the origin of metamerism are associated with those on the origin of the coelom. The most frequent ones found in textbooks are the enterocoelic theory (REMANe 1956) and the hydrostatic theory (CLARK 1963, 1964). The enterocoelic theory envisions a simultaneous origin of the coelom and of segmentation, as a consequence of the ontogeny of the mesoderm. However, besides difficulties encountered in establishing a direct relation of homology between different types of mesoderm and body cavities, one of the most inelegant consequences of this proposal is to consider flatworms as belonging to the clade of metameric and coelomate animals.

The hydrostatic theory avoids generalizations such as the above, being by far the most generally accepted theory. For Clark $(1963,1964)$, the origin of the coelom is linked to the evolution of a burrowing way of life. Animals with a hydrostatic skeleton supposedly would have an advantage over acoelomate forms for burrowing. From this point of view, body cavities could have been under selective pressure to evolve several times independently for a fossorial habitat within the Metazoa Haeckel, 1874. The body division into segments would represent an additional improvement for living within the substratum. Again, such a favorable selection pressure would have produced metamery several times independently within the Metazoa (Clark 1963, 1964).

The results of the present cladistic analyses reject both of these scenarios. The available evidence does not permit the rejection of an initial hypothesis of homology of the body cavities. Compartimented body segments with fluid cavities delimited by peritomium are present in all metamerians (except 
Table I. List of characters used. 0 , plesiomorphic state; $1-4$, successively apomorphic states.

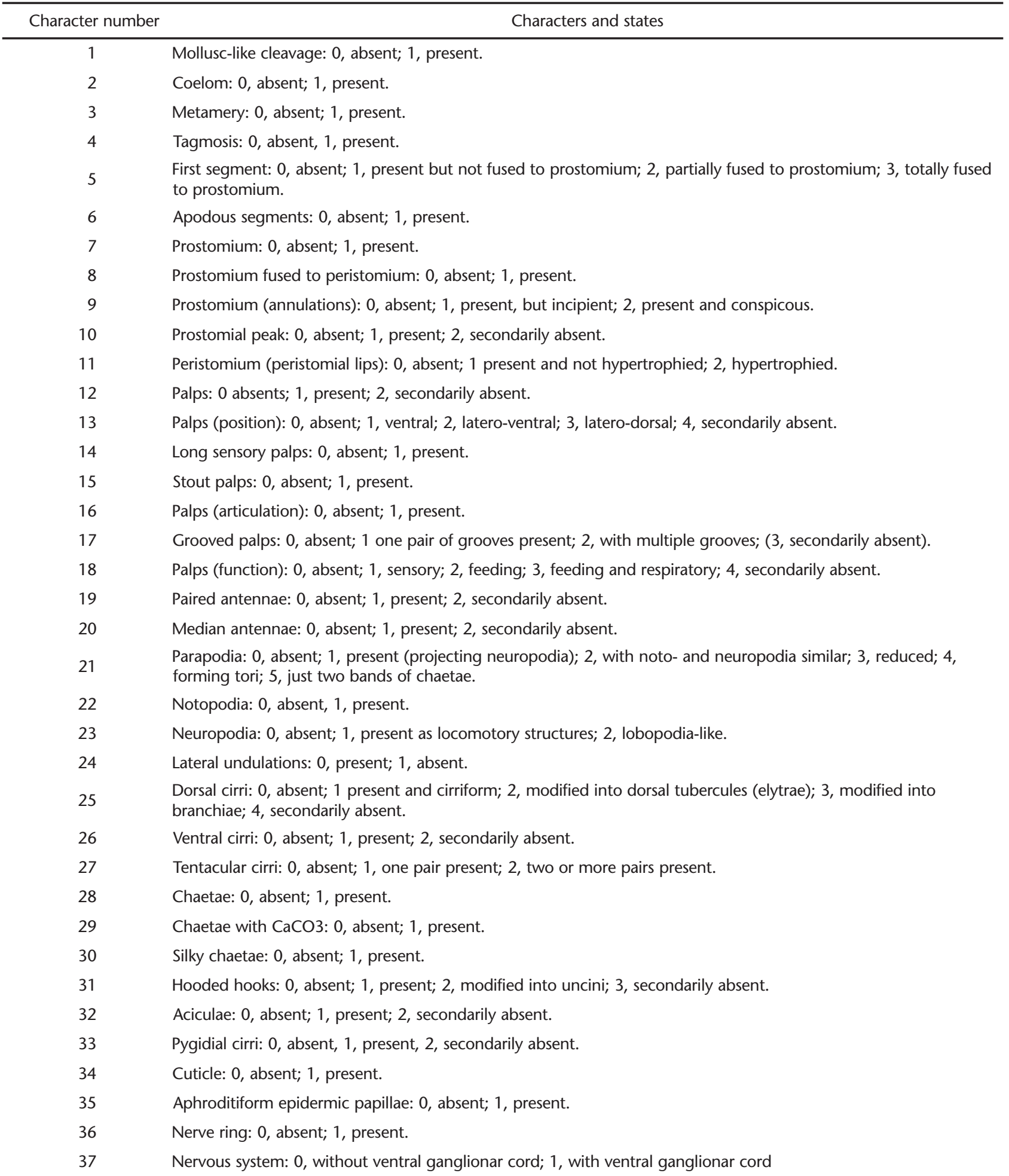


Table I. Continued.

\begin{tabular}{|c|c|}
\hline Character number & Characters and states \\
\hline 38 & Nuchal organs: 0 , absent; 1 , present; 2 , secondarily absent. \\
\hline 39 & Nuchal organs (caruncle): 0 , absent; 1 , present. \\
\hline 40 & Lateral organs: 0 , absent; 1 , present; 2 , secondarily absent. \\
\hline 41 & $\begin{array}{l}\text { Pharynx: } 0 \text {, not eversible; } 1 \text {, eversible and axial; } 2 \text {, eversible, ventral and muscularized; } 3 \text { eversible, ventral and not } \\
\text { muscularized; } 4 \text {, eversible and sac-like. }\end{array}$ \\
\hline 42 & Transversal groove of the pharynx: 0 , absent, 1 , present. \\
\hline 43 & Jaws (circlet disposition): 0 , absent; 1 , present. \\
\hline 44 & Jaws (dorso-ventral disposition): 0 , absent; 1 , present; 2 , reduced or secondarily absent. \\
\hline 45 & Maxilae and supports: 0 , absent; 1 , present and labdognath; 2 , reduced and ctenognath. \\
\hline 46 & Ridged pharynx: 0 , absent, 1 , present. \\
\hline 47 & Buccal organ: 0 , absent, 1 , present. \\
\hline 48 & Digestive system complete: 0 , absent; 1 , present. \\
\hline 49 & Excretory system: 0 , protonephridial; 1 , metanephridial; 2 , secondarily protonephridial. \\
\hline 50 & A pair of anterior nephridia: 0 , absent; 1 , present. \\
\hline 51 & Dorsal nephridiopore: 0 , absent; 1 , present. \\
\hline 52 & Larval nephridia deuterostom-like: 0 , absent; 1 , present. \\
\hline 53 & Clitellum: 0 , absent; 1 , present. \\
\hline 54 & Reproductive organs in specified segment: 0 , absent; 1 , present. \\
\hline 55 & Two pair of the anterior ovarious: 0 , absent; 1 , present. \\
\hline 56 & Opening of the gonoduct in segment $14: 0$, absent; 1 , present. \\
\hline 57 & Spermatecae: 0 , absent; 1 , present. \\
\hline 58 & Larva and development: 0 , planula; 1 , trocophore; 2, mitraria; 3, tornaria; 4, larvae absent (development direct). \\
\hline 59 & Ciliar arrangement in larvae deuterostom-like: 0 , absent; 1 , present. \\
\hline 60 & Catastrophic metamorphosis: 0 absent; 1, present. \\
\hline
\end{tabular}

in many ecdysozoans in which they may be totally reduced to a "pseudocoel" or absent). Furthermore, the enterocoelic type of coelom formation may be considered an apomorphic, secondary modification of the schizocoelic pattern with teloblastic development (Christoffersen \& Araújo-De-Almeida 1994). The present hypothesis differs from the enterocoelic theory because we invert the polarity of body cavities (enterocoely becomes derived instead of primitive) and by our unlinking the characters coelom and metamerism. Body cavities appear before metamerism in the history of the Metazoa.

Optimization of ecological features over the phylogeny furnishes no evidence whatsoever for the hypotheses that the coelom and metamerism are associated with a burrowing habit (Clark 1963, 1964). The first body cavities are seen in Nemertea, where they are used as hydrostatic devices (rhynchocoels) for everting the proboscis (BRUSCA \& BRUSCA 1990), even though this may not be the original function in the groundplan of the Coelomata Christoffersen \& Araújo-de-Almeida, 1994. The body cavity in Nemertea may be considered an exaptation (preadaptation), subsequently modified for other functions, such as providing an hydrostatic body skeleton, promoting the circulation of body fluids, producing space for the maturation of reproductive cells, etc. (HyMAN 1951; BrusCa \& BRUSCA 1990; TuRbeville 1991). Most metameric marine animals that dig into the substrate have the septae reduced or totally absent (e.g., Sipuncula Sedgwick, 1898, Glyceridae Grube, 1850, Goniadidae Kinberg, 1866, and Arenicolidae Johnston, 1835 among others). On the other hand, the mesenteric septae are well developed in some tubicolous forms and in most errant polychaetes (CLARK 1962; Willmer 1990). These observations give little support for a correlation between septae and particular life styles. The analysis of ALmeIDA \& CHRISTOFFERSEN (2000) favors the hypothesis of BonicK et al. (1976) and WestheIDE (1997) for some sort of association between the metameric septae and the development of parapodia (Fig. 3). The septae contain blood vessels for the irrigation of the parapodia and muscles that may facilitate lateral body undulations when the animals move (WeSTHEIDE 1997). However, we further sustain that this scenario of the origin of metamerism in Polychaeta and Arthropoda is also shared with the deuterostomes (Enterocoela). Owenia delle Chiaje, 1841 and Pogonophora provide clear successive connecting links between the traditional protostome and

Revista Brasileira de Zoologia 20 (1): 23-57, março 2003 


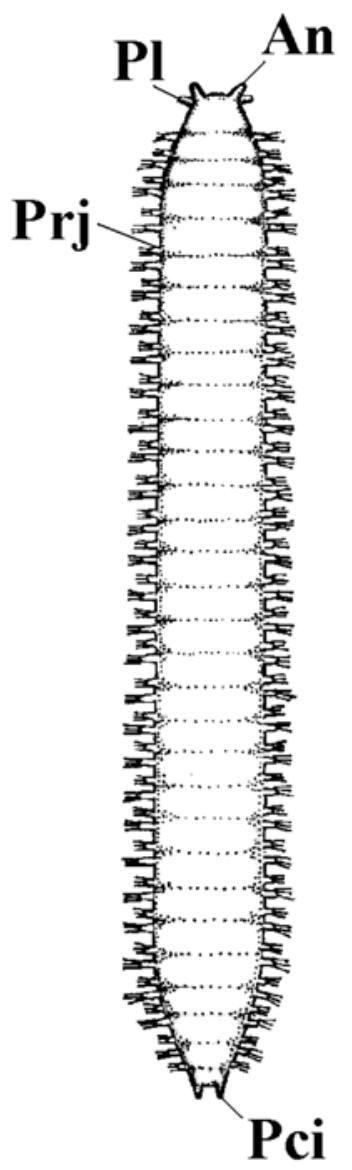

Figure 3. Groundplan of Metameria obtained by adding synapomorphies from ALMEIDA \& ChRISTOFFERSEN (2000). An, lateral antennae; Pci, pigidial cirri; Pl, palps; Prj, projecting neuropodia.

deuterostome conditions. The present hypotheses of relationships have antecedents in the proposals of GEOFFROY Saint-Hillaire (1822) and Dohrn (1875), both of whom proposed the origin of the Vertebrata from annelid-like ancestors.

The morphological hypothesis detailed above is strongly corroborated by two other types of empirical data: (1) The burgeoning evidence of homology of the Hox genes that control segment formation in protostomes and deuterostomes (McGinnis et al. 1984; Lawrence 1990; François \& Bier 1995; Holley et al. 1995; Jones \& SMith 1995; Holland et al. 1997; Shubin et al. 1997; Panganiban et al. 1997; Peterson \& Davidson 2000; Peterson et al. 2000a, b); and (2) the growing evidence for homologous developmental patterns shared by protostomes and deuterostomes (Weisblat et al. 1993; NüBler-Jung \& ARENDT 1994, 1999; Arendt \& NÜbler-Jung 1994, 1997, 1999).

Sequence data (e.g., 18S rRNA, $12 \mathrm{~S}$ rRNA, $18 \mathrm{~S}$ rDNA, etc.) have produced molecular phylogenies which maintain the traditional divergence between Protostomia Grobben, 1908 and Deuterostomia Grobben, 1908, and suggest a distant relationship between Annelida and Arthropoda (Field et al.
1988; BALLARD et al. 1992; WINNEPENNINCKX et al. 1992, 1998; Eernisse et al. 1992; Kim et al. 1996; Garey et al. 1996, 1998; Aguinaldo et al. 1997; Eernisse 1997; Giribet \& Ribera 1998; ZrZAVÝ et al. 1998; SCHIMIDT-RHAEsA et al. 1998). The heuristic value of these sequence data is clearly inferior to the genotypicphenotypic data produced from shared orthologous genes. As Wägele $(1995,1996 b, 1999)$, Wägele \& WetZel (1994) and WäGELE et al. (1999) have stressed, many analyses of sequence data are not based on explicit phylogenetic criteria and result essentially from numerical analyses of similarities. There is ample evidence that these results are strongly dependent on sample size, selected organisms, types of sequences used, and chosen methods of analyses (WÄGELE \& WeTzeL 1994; WäGELE 1995; Siddall et al. 1998; Aleshin et al. 1998; Wägele et al. 1999; Aleshin \& Petrov 1999). Philippe et al. (1994) further demonstrated that, for cladogenetic events occurring before $400 \mathrm{Myr}$ ago, data from $18 \mathrm{~S}$ rRNA are definitely not reliable. Aleshin \& Petrov (1999: 196) and Giribet \& Ribera (2000: 225) also presented results indicating that phylogenies based on rDNA sequence may not contain enough information to give a satisfactory explanation for the large and complicated evolutionary history of arthropods. For all these reasons a skeptical posture was assumed regarding the phylogenetic significance of sequence data that differ from other types of comparative information analyzed in a phylogenetic context. Like the phenetic analyses of morphological data, many of the taxonomic arrangements proposed by molecular biologists may be based on plesiomorphic similarities and/or convergences.

Homeobox genes have recently been discovered in Platyhelminthes (Balavoine \& Telford 1995; Balavoine 1996). This led Balavoine $(1997,1998)$ to develop the idea that Platyhelminthes are highly modified coelomates. This hypothesis was not adopted here, because it is possible that the homeoboxes of Platyhelminthes are only responsible for the expression of the antero-posterior body axis, and possibly also of the serial organs (e.g., gonads in triclad tuberlarians; Hyman 1951: 26). There is no direct evidence that Platyhelminthes have coeloms or derive from coelomate or metameric ancestors. The generality of Hox genes simply extends to the base of the Metazoa (Peterson \& Davidson 2000). The discovery of homeobox genes in Platyhelminthes is very interesting, but may be misleading if interpreted under preestablished evolutionary scenarios (such as the gonocoelic or enterocoelic theories). The present hypotheses on metazoan phylogeny have very old roots (e.g., GeOFFroy SAINT-HiLLaIRE 1822; DoHrN 1875), but must also include the latest evidence, and the older views must be modified accordingly. The case of the Platyhelminthes provides a good example of this problem. The coelom appears at the base of Coelomata and in Nemertea it is used for everting the proboscis, while mesenteric septae and a ventral ganglionated nerve cord appear in Metameria associated with the development of parapodia (BonICK et al. 1976; WestheIde 1997). Thus the origin of the coelom and the origin of metamerism are decoupled in evolution. The presence of homeobox genes in Platyhelminthes is not incongruent with this scenario. A repetition of structures may be found also in the scoleces of cestode flatworms, in Mollusca Linnaeus, 1758 (Haszprunar 1992; Scheltema et al. 1994), and apparently also in the Precambrian metazoan Dickinsonia Sprigg, 1947 (RUNNEGAR 1982). A repetition of structures thus seems to precede both the origin of the mesodermic body cavities and the origin of the mesodermic metameres. The true novelty of

Revista Brasileira de Zoologia 20 (1): 23-57, março 2003 
metameric animals would consist in their reorganizing their body for a new system of locomotion that relies on metameric appendages. With this functional reorganization, preexisting plesiomorphies, such as homeobox genes, a hydrostatic skeleton, and a repetition of internal organs, have all been coopted for the walking-invention. Data suggests, hence, that homeobox genes are plesiomorphic for the Coelomata. Said in another way, metamerism is not to be interpreted as the direct phenotypic expression of homeobox genes.

Both tagmosis (functional specialization of groups of metameres) (Tab. I, \#4) and reduction of the total number of metameres are accepted as apomorphic. The latter trend occurs in several tubicolous lineages such as Terebellida and Sabellida, and in burrowing forms such as Arenicolidae Johnston, 1835 and Maldanidae Malmgren, 1867. These polarities reestablish the traditional view that heteronomous polychaetes are derived in relation to those with a largely homonomous pattern of segmentation (Fauvel 1923). With Owenia positioned as the sister group of Enterocoela, several genetic patterns of tagmosis found in basal groups of deuterostomes (PETERSON et al. 2000a) are also seen to be found in polychaetes, providing further empirical support for the present hypothesis.

The first segment (Tab. I, \#5) may be partially or totally fused to the cephalic tagma in Phyllodocida and in the basal groups of eunicids and related taxa (Nephtyidae Grube, 1850 and Amphinomidae Savigny, 1818) (Fig. 4). The following segments may also be cephalized, as in Phyllodocidae Örsted, 1843 (Day 1967; SChröder \& Hermans 1975; Fauchald 1977; Glasby 1993; Fauchald \& Rouse 1997). These characters are considered apomorphies for these clades, which is congruent with the interpretations of Glasby (1993), Rouse \& Fauchald (1997), Plejel \& Dahlgren (1998), and Almeida \& Christoffersen (2000). Evidence for or against the homology of the head tagma of Polychaeta with that of Ecdysozoa is still lacking.

With the total cephalization of the first metamere, parapodial structures such as neuropodia, notopodia and chaetae are not expressed. The only structures that indicate their metameric origin are the parapodial cirri (now called tentacular cirri) (Fig. 4). In Nereididae, the first pair of tentacular cirri appears on the peristomial region (e.g., BLAKE 1975) and their inervation patterns are indicative of a segmental origin (ORRHAGE 1993). If this first pair of cirri were not present, no evidence would be available to indicate that the anterior collar region in Nereididae Johnston, 1865 is metameric. Such segmental inervation could have been lost in Dorvilleidae Chamberlin, 1919 (see EIвуе-JACOBSEN 1994), if the peristomial cirri of Onuphidae Kinberg, 1865 and Eunicidae Berthold, 1827 are equivalent to the tentacular cirri of Phyllodocida (Fig. 4). In any case, many representatives of Sedentaria have one or two anterior apodous rings (Tab. 1, \#6): Spionida (Magelonidae), Terebellida (Cirratulidae, Alvinellidae, Ampharetidae, Terebellidae, and Trichobranchidae), and scolecids (Arenicolidae, Capitellidae, Maldanidae, and Questidae) (see FAUCHALd \& Rouse 1997).

\section{Prostomium and peristomium have dynamic boundaries}

A traditional definition of the prostomium (Tab. I, \#7) is the following: situated anteriorly, delimited from trunk by a groove, of pre-trochal origin, and containing in the adult at least part of the supra-oesophageal ganglion. Sensory appendages (antennae and palps) and photo-sensory organs (ocelli) are regularly present on the prostomium (FAUVEL 1959; Fauchald 1977; Pettibone 1982; George \& Hartmann-Schröder 1985; Fauchald \& Rouse 1997) (Figs 4 and 5).

Typological descriptions such as the above, when interpreted as immutable patterns, may generate confusion in the interpretation and delimitation of this structure. For example, if the prostomium corresponds to the pre-trochal anterior region of the trochophore larvae, then Mollusca and Sipuncula have a cephalic region of identical origin (see HyMAN 1959; Scheltema et al. 1994; Cutler 1994) and thus all three taxa should have homologous prostomia.

The groove that delimits the prostomium of annelids represents a redundant structure, because it results from body segmentation. In other words, non-metameric groups obviously do not have a head separated from the trunk by a groove. It may also be difficult to characterize the prostomium as the region that contains the supra-oesophageal ganglion, because in Clitellata this ganglion may be significantly displaced posteriorly (HessLING \& WestheIDE 1999).

The presence of sensory structures is also not a good solution to characterize the prostomium, because many specialized Sedentaria, such as the scolecids, usually do not have palps, antennae or ocelli, and this absence does not characterize them as polychaetes without a prostomium.

The more basal forms of Ecdysozoa (except Kerigmachela Budd, 1993) also do not present sensory cephalic structures (Budd 1993, 1996). On the other hand, the anterior region, or acron, of Crustacea Pennant, 1777 bears cephalic appendages and contains part of the supra-oesophageal ganglion (SCHRAM 1986; SCHRAM \& EMERSON 1991). In both cases it is very difficult to establish either the presence or the absence of a typical prostomium in Ecdysozoa. Because of the above difficulties, presence of a pre-prototrochal cephalic region may be a synapomorphy of the clade Mollusca + Sipuncula + Metameria (Tabs. II and III).

The different degrees of fusion between the preprototrochal (prostomial) and prototrochal (peristomial) regions (Tab. I, \#8), sometimes also involving the first metamere, are derived conditions in Metameria. This fusion was coded as a single character. This may form a "distinct head" in Maldanidae and Paraonidae (here provisionally included in Paraonida), a "tentacular crown" in the Sabellida or a "joint foliose, saddle-shaped, structure" in the Terebellida (PILGrim 1966; Holthe 1986; Rouse \& Fitzhugh 1994) (Fig. 5). The latter two conditions are clearly autapomorphies of the Sabellida and Terebellida, respectively. But more information is needed to resolve if the simpler head of Maldanidae and Paraonidae could represent a homologous stage towards the latter conditions avoiding an essentialistic coding of the character.

Despite much variation in the shape of the prostomium - e.g., "T-shaped" in Spionida or forming an "inverted T" in Nereididae (DAY 1967; FAUCHALD 1977) -,only the annulation of the prostomium in Glyceridae and Goniadidae was considered as forming a synapomorphy (see HARTMAN 1950) (Tab. I, \#9). This hypotheses agrees with that of НАNsтRÖм (1928, 1930), in which the prostomium of the Glyceridae and of the Goniadidae are very complex and derived structures. In the figures of PetTibone (1963: fig. 46) and Day (1967: fig. 15e), an apparent annulation is also observed in Paralacydoniidae Pettibone, 1963. These annuli may represent a synapomorphy 


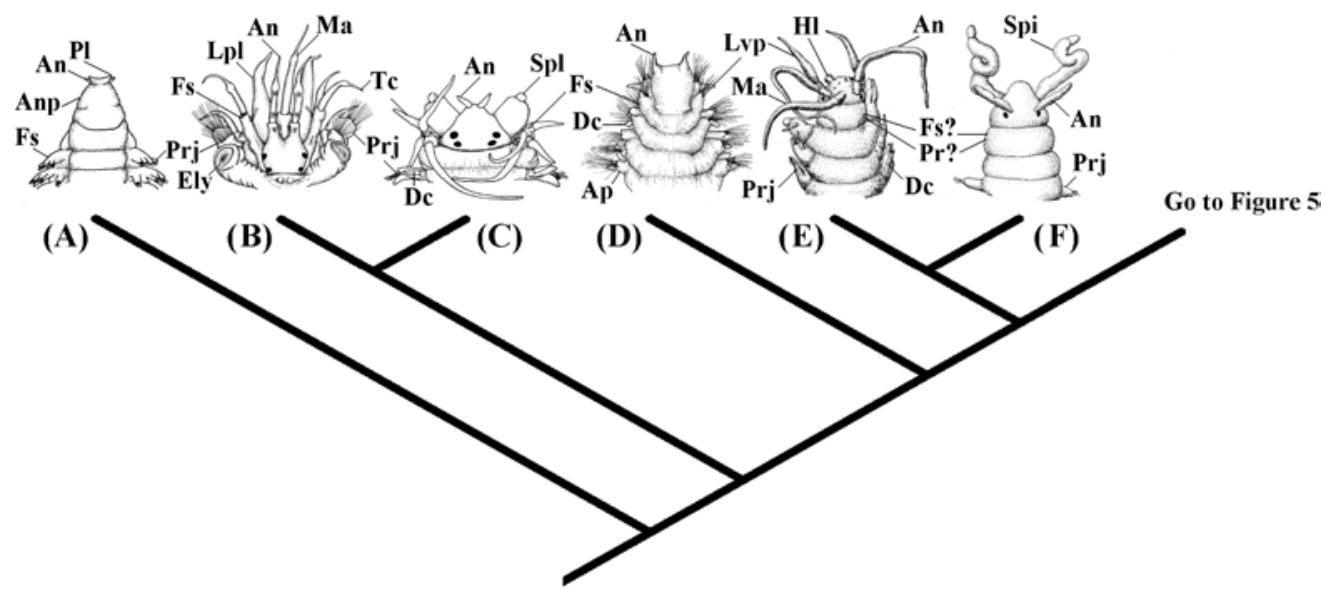

Figure 4. General scenario for the main modifications of many anterior morphological characters of the errant metameric lineages (in dorsal view). (A) Paralacydoniidae represented by Paralacydonia paradoxa Fauvel, 1913 (modified from PetTiBone 1963); (B) Scale worms represented by Lepidonotus caelorus Kinberg, 1866 (Polynoidea) (modified from IMAIIMA 1997); (C) Phyllodocyformia represented by Nereis diversicolor Müller, 1776 (Nereididae) (modified from BöGGEMANN 1997); (D) Basal group of Eunicida represented by Aglaophamus gippslandicus Rainer \& Hutchings, 1977 (Nephtyidae) (modified from IMAIIMA \& TAKEDA 1985); (E) Eunicidae represented by Hyalinoecia tubicola Müller, 1766 (Onuphidae) (modified from George \& HarTMAnN-Schröder 1985); (F) Dorvilleidae represented by Protodorvillea kefersteini McIntosh, 1869 (modified from GeORGE \& HARTMANN-SChröDer 1985). An, lateral antennae; Anp, annulated prostomium; Ap, amphinomid-like parapodia; Dc, dorsal cirri; Ely, elytrophore; Fs, first segment; Hi, hypertrophied peristomial lips; Lpl, long sensory palps; Lvp, latero-ventral palps; Ma, median antennae; Pl, palps; Pr, peristomial ring; Prj, projecting neuropodia; Spi, spionimorph palps; Spl, stout articulated palps; Tc, tentacular cirri.

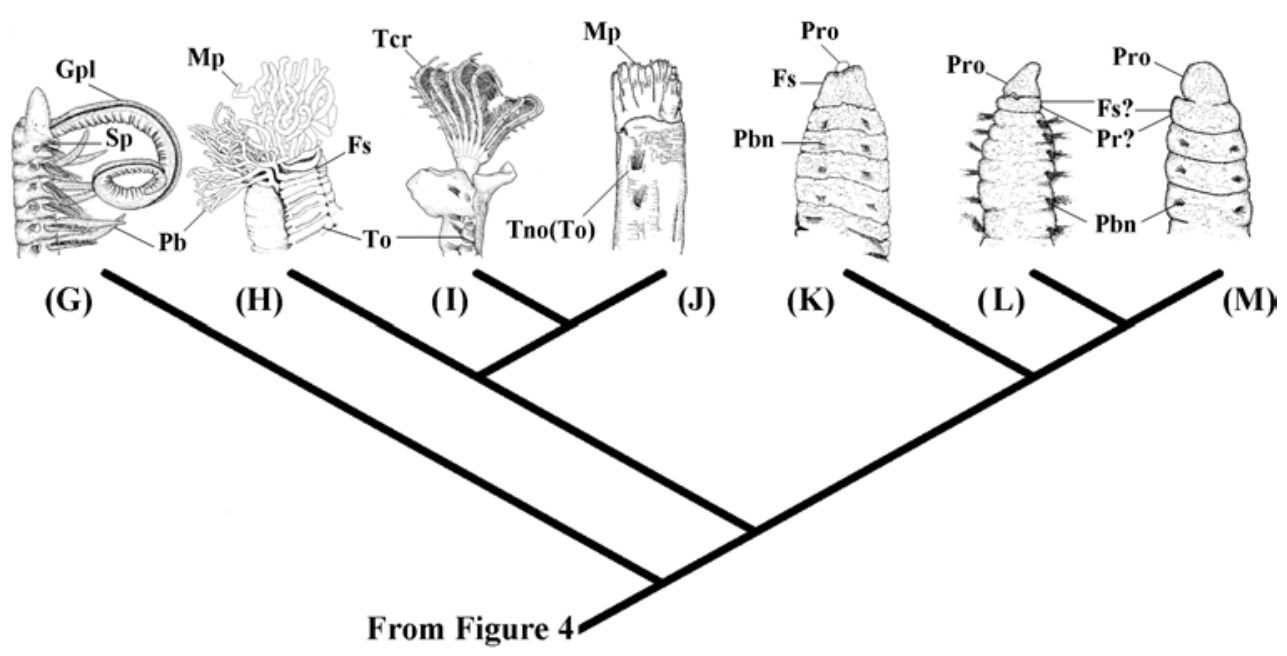

Figure 5. Further scenario for main modifications of many anterior morphological characters of the sedentary metameric lineages (in lateral view). (G) Spionida represented by Aonides oxycephala (Sars 1862) (Spionidae) (modified from IMAJIMA 1989); (H) Terebellida represented by Nicolea amnis Hutchings \& Murray, 1984 (Terebellidae) (modified from Hutchings \& MurRaY 1984); (I) Sabellida represented by Dasynema chrysogyrus (Grube 1876) (Sabellidae) (modified from IMAIIMA \& Hove 1984); (J) Owenia represened by Owenia fusiformis delle Chiaje, 1842 (Oweniidae) (modified from IMAJIMA \& MoRITA 1987); (K) Capitellidae represented by Notomastus estuarius Hutchings \& Murray, 1984 (HutchInGs \& MurRaY 1984); (L) Questidae represented by Questa caudicirra Hartman, 1966 (modified from FAUCHALD 1977); (M) Clitellata represented by Phallodrilus riparius Giani \& Martinez-Ansemil, 1981 (Tubificidae) (modified from GIANI \& MARTINEZANSEMIL 1981). Fs, first segment; Gpl, grooved palps; Mp, multiple palps; Pb, parapodial branchiae; Pbn, parapodial chaetal bundles; Pr, peristomial ring; Pro, prostomium; Sp, spionimorph parapodia; Tcr, tentacular crown, Tno, truncate notopodia; To, tori. 
Table II. Data matrix used in cladistic analyses of the positive series. (0-4) Ordered transformation series, (?) character information absent or dubious.

\begin{tabular}{|c|c|c|c|c|c|c|}
\hline \multirow[b]{2}{*}{ Taxa } & \multicolumn{6}{|c|}{ Characters } \\
\hline & 1234567890 & $\begin{array}{l}1111111111112 \\
12334567890\end{array}$ & $\begin{array}{l}2222222223 \\
1234567890\end{array}$ & $\begin{array}{l}3333333334 \\
1234567890\end{array}$ & $\begin{array}{l}4444444445 \\
1234567890\end{array}$ & $\begin{array}{l}5555555556 \\
1234567890\end{array}$ \\
\hline Platyhelminthes & 0000000000 & 0000000000 & 0000000000 & 0000000000 & 0000000000 & 0000000000 \\
\hline Nemertea & 0100000000 & 0000000000 & 0000000000 & 0000000000 & 0000000100 & 0000000000 \\
\hline Sipuncula & 1100001000 & 0000000000 & 0000000000 & 0000010000 & 0000000110 & 0000000100 \\
\hline Mollusca & 1100001000 & 0000000000 & 0000000000 & 0000010000 & 0000000110 & 0000000100 \\
\hline Paralacydoniidae & 0110101010 & 1110000110 & 1111110100 & 0111011100 & $10000001 ? 0$ & 0000000100 \\
\hline Glyceridae & 0110101020 & 1110000110 & 1111110100 & 0111011100 & 1010000100 & 0000000100 \\
\hline Goniadidae & 0110101020 & 1110000110 & 1111110100 & 0111011100 & 1010000100 & 0000000100 \\
\hline Pisionidae & 0110201000 & 1111000110 & 1111111100 & 0111011000 & 1001000100 & 0000000100 \\
\hline Sigalionoidea & 0110201000 & 1111000111 & 1111211100 & 0111011100 & 1001000110 & 0000 \\
\hline Polynoidea & 0110201001 & 1111000111 & 1111211101 & 0111011100 & 1001000110 & 0000000100 \\
\hline Aphrodita & 0110201000 & 1111000101 & 1120211101 & 0111111100 & 1001000110 & 0000000000 \\
\hline Ecdysozoa & $011 ? ? ? 1 ?$ ? 0 & ?? ? ? ? ? ? 0? & ?? 202 ? ?? ?? & ?? ? 111100 ? & ?? $00000 ? 110$ & $000 ? ? ?$ ? 0 ?? \\
\hline Lacydoniidae & 0110301000 & 1110000111 & 1111111100 & 0111011100 & $10000001 ? 0$ & 0000000100 \\
\hline Phyllodocidae & 0110301000 & 1110000111 & 1111112100 & 0111011100 & 1000000100 & 0000000100 \\
\hline Syllidae & 0110301000 & 1110000111 & 1111112100 & 0111011100 & 1100000110 & 0000000100 \\
\hline Nereididae & 0110301000 & 1110110110 & 1111112100 & 0111011100 & 1100000110 & 0000000100 \\
\hline Pilargidae & 0110301000 & 1110110111 & 1111111100 & 0111011100 & 110000 & 100 \\
\hline Nephtyidae & 0110101000 & 1120000110 & 2111110100 & 0111011100 & 1000000100 & 0000000100 \\
\hline Amphinomidae & 0110101000 & 1120000111 & 2111310110 & 0111011110 & 2000010110 & 0000000100 \\
\hline Euphrosinidae & 0110101000 & 1120000111 & 2111310110 & 0111011110 & 2000010110 & 100 \\
\hline Eunicidae & $0110 ? ? 1000$ & 2120000111 & $111131 ? 100$ & 1111011100 & 2000101110 & 0000000100 \\
\hline Onuphidae & $0110 ? ? 1000$ & 2120000111 & $111131 ? 100$ & 1111011100 & 2000101110 & 0000000100 \\
\hline Dorvilleidae & $0110 ? ? 1000$ & 1120001111 & 1111310100 & 1111011100 & 2000101110 & 0000000100 \\
\hline Spionida & $0110 ? 11000$ & 1130001201 & 3111300100 & 1011011101 & 3000001110 & 0100 \\
\hline Terebellida & $0111 ? 11100$ & 1130002300 & 4111300100 & 2011011101 & 3000001111 & $? 000000100$ \\
\hline Sabellida & $0111 ? 11100$ & 1130002300 & 4111300100 & 2011011101 & 3000001111 & 1000000100 \\
\hline Owenia & $0111 ? 11100$ & 1130002200 & 4111000100 & 2011011101 & 3000001111 & 1100000211 \\
\hline Enterocoela & $0111 ? 11100$ & 1130002200 & 4111000100 & $20 ? ? 011001$ & $? 000000 ? 111$ & 1100000311 \\
\hline Paraonida & $0111 ? 11000$ & 1000000001 & 4111300100 & 1011011001 & 4000001110 & 0000000100 \\
\hline Questidae & $0111 ? 11000$ & 1000000000 & 4111300100 & 1011011101 & 4000001110 & 0011111400 \\
\hline Clitellata & $0111 ? 11000$ & 1000000000 & 5111000100 & 0011011001 & $? 00000 ? 110$ & 0011111400 \\
\hline Ophellidae & $0111 ? 11000$ & 1000000000 & 4111300100 & 0001011101 & 4000001110 & 0000000010 \\
\hline Capitellidae & $0111 ? 11000$ & 1000000000 & 4111000100 & 1001011101 & 4000001110 & 0000000010 \\
\hline Arenicolidae & $0111 ? 11000$ & 1000000000 & 4111300100 & 1001011100 & 4000001110 & 0000000010 \\
\hline Maldanidae & $0111 ? 11000$ & 1000000000 & 4111300100 & 1001011100 & 4000001110 & 0000000010 \\
\hline
\end{tabular}

Revista Brasileira de Zoologia 20 (1): 23-57, março 2003 
Table III. Data matrix used in cladistic analyses of the negative series. (0-4) Ordered transformation series, (?) character information absent or dubious.

\begin{tabular}{|c|c|c|c|c|c|c|}
\hline \multirow[t]{2}{*}{ Taxa } & \multicolumn{6}{|c|}{ Characters } \\
\hline & 1234567890 & $\begin{array}{r}11111111112 \\
1234567890 \\
\end{array}$ & $\begin{array}{l}2222222223 \\
1234567890 \\
\end{array}$ & $\begin{array}{l}3333333334 \\
1234567890 \\
\end{array}$ & $\begin{array}{l}4444444445 \\
1234567890\end{array}$ & $\begin{array}{r}5555555556 \\
1234567890 \\
\end{array}$ \\
\hline & 1234567890 & 1234567890 & 1234567890 & 1234567890 & 1234567890 & 1234567890 \\
\hline Platyhelminthes & 0000000000 & 0000000000 & 0000000000 & 0000000000 & 0000000000 & 0000000000 \\
\hline Nemertea & 0100000000 & 0000000000 & 0000000000 & 0000000000 & 0000000100 & 0000000000 \\
\hline Sipuncula & 1100001000 & 0000000000 & 0000000000 & 0000010000 & 0000000110 & 0000000100 \\
\hline Mollusca & 1100001000 & 0000000000 & 0000000000 & 0000010000 & 0000000110 & 0000000100 \\
\hline Paralacydoniidae & 0110101010 & 1110000110 & 1111110100 & 0111011100 & $10000001 ? 0$ & 0000000100 \\
\hline Glyceridae & 0110101020 & 1110000110 & 1111110100 & 0111011100 & 1010000120 & 0000000100 \\
\hline Goniadidae & 0110101020 & 1110000110 & 1111110100 & 0111011100 & 1010000120 & 0000000100 \\
\hline Pisionidae & 0110201000 & 1111000112 & 1111111100 & 0111011200 & 1001000120 & 0000000100 \\
\hline Sigalionoidea & 0110201000 & 1111000111 & 1111211100 & 0111011100 & 10010 & 000 \\
\hline Polynoidea & 0110201001 & 1111000111 & 1111211101 & 0111011100 & 1001000110 & 0000000100 \\
\hline Aphrodita & 0110201002 & 1111000121 & 1122211101 & 0111111100 & 1002000 & 0000000400 \\
\hline Ecdysozoa & $011 ? ?$ ?? ? ? & ? ? ? ? ? ? ? 2 ? & ? ? 222 ? ? ? ? ? & ??? 111120 ? & ??0200? 110 & $000 ? ? ?$ ? 4 ?? \\
\hline Lacydoniidae & 0110301000 & 1110000111 & 1111111100 & 0111011100 & $10000001 ? 0$ & 0000000100 \\
\hline Phyllodocidae & 0110301000 & 1110000111 & 1111112100 & 0111011100 & 120 & 100 \\
\hline Syllidae & 0110301000 & 1110000111 & 1111112100 & 0111011100 & 110000 & 0000000100 \\
\hline Nereididae & 0110301000 & 1110110112 & 1111112100 & 0111011100 & 1100000110 & 0000000100 \\
\hline Pilargidae & 0110301000 & 1110110111 & 1111111100 & 0111011100 & 110 & 0000000100 \\
\hline Nephtyidae & 0110101000 & 1120000112 & 2111110100 & 0111011100 & 1000000120 & 0000000100 \\
\hline Amphinomidae & 0110101000 & 1120000111 & 2111310110 & 0111011110 & 110 & 0000000100 \\
\hline Euphrosinidae & 0110101000 & 1120000111 & 2111310110 & 0111011110 & 2000010110 & 0000000100 \\
\hline Eunicidae & $0110 ? ? 1000$ & 2120000111 & $111131 ? 100$ & 1111011100 & 101110 & 000 \\
\hline Onuphidae & $0110 ? ? 1000$ & 2120000111 & $111131 ? 100$ & 1111011100 & 2000101110 & 000 \\
\hline Dorvilleidae & $0110 ? ? 1000$ & 1120001111 & 1111310100 & 1111011100 & 2000101110 & 0000000100 \\
\hline Spionida & $0110 ? 11000$ & 1130001221 & 3111320100 & 1211011101 & 1110 & 0000000100 \\
\hline Terebellida & $0111 ? 11100$ & 1130002322 & 4111320100 & 2211011101 & 3000001111 & $? 000000100$ \\
\hline Sabellida & $0111 ? 11100$ & 1130002322 & 4111320100 & 2211011101 & 3000001111 & 1000000100 \\
\hline Owenia & $0111 ? 11100$ & 1130002222 & 4111420100 & 2211011101 & 3000001111 & 1100000211 \\
\hline Enterocoela & $0111 ? 11100$ & 1130002222 & 4111420100 & $22 ? ? 011201$ & $? 00000 ? 111$ & 1100000311 \\
\hline Paraonida & $0111 ? 11000$ & 1240003421 & 4111320100 & 1211011201 & 4000001110 & 0000000100 \\
\hline Questidae & $0111 ? 11000$ & 1240003422 & 4111320100 & 1211011101 & 4000001110 & 0011111400 \\
\hline Clitellata & $0111 ? 11000$ & 1240003422 & 5111420100 & 3211011201 & $? 00000 ? 110$ & 0011111400 \\
\hline Ophellidae & $0111 ? 11000$ & 1240003422 & 4111320100 & 3221011101 & 4000001110 & 0000000010 \\
\hline Capitellidae & $0111 ? 11000$ & 1240003422 & 4111420100 & 1221011101 & 4000001110 & 0000000010 \\
\hline Arenicolidae & $0111 ? 11000$ & 1240003422 & 4111320100 & 1221011102 & 4000001110 & 0000000010 \\
\hline Maldanidae & $0111 ? 11000$ & 1240003422 & 4111320100 & 1221011102 & 4000001110 & 0000000010 \\
\hline
\end{tabular}


for these three taxa, although further confirmation in Paralacydoniidae is needed.

In some Polynoidae (here included in Polynoidea) the prostomium has small projections, or "prostomial peaks" (Pettibone 1963, 1989; Day 1967) (Tab. I, \#10). There is no information on the function of these prostomial peaks, but find it reasonable to suppose that they have a tactile-sensorial function. In Polynoidea, prostomial projections are also found in acoetids and aphroditids (Pettibone 1989; Watson Russell 1989; Hutchings \& McRae 1993). In the latter groups these sensitive structures occur in the same position, but may sometimes be photosensorial, because of the presence of ocelli in some acoetids (see Petтibone 1989), and in other cases only tactile-sensitive, as in Laetmonice producta Grube, 1878 (see Hutchings \& McRae 1993). Although the resolution of interrelationships between all the scaly worms lies beyond the objectives of this paper, some decisions regarding the basal plan of Aphrodita have made (Almeida \& ChristofFersen 2000). Eupanthalis McIntosh, 1876 may be one of the most basal groups among the Acoetidae, because of the high number of body segments, lateral antennae, and absence of ocular peduncles. These characters contrast in particular with many polynoids. On the other hand, some genera of Polynoidea (e.g. Lepidonotopodium Pettibone, 1983; Ретtibone 1983, 1984; DesbruYìres \& Hourdez 2000a, b) may have less than 60 body segments, an oval body shape, while lateral antennae are absent. These characters are also shared with Aphrodita, and thus genera such as Lepidonotopodium may represent a transition between polynoids and aphroditids, while acoetids could have other still undetermined relationships among the scaly worms.

Rouse \& FAUCHALD (1997) considered the spinning glands to be synapomorphic for Acoetidae and Aphroditidae. However, they may represent independent acquisitions in these two taxa. The same applies to the ocular peduncles, which do not appear to be present in the basic plan of the Acoetidae.

Comparing the ocular peduncles of Aphroditidae with the prostomial peaks present in genera of polynoids such as Lepidonotopodium (see Pettibone 1983, 1984; Desbruyères \& Hourdez $2000 \mathrm{a}, \mathrm{b}$ ), the following hypotheses may be made: (1) they represent independent structures; or (2) they are homologous. The first hypothesis begs the question of why groups so close as polynoids with prostomial peaks and aphroditids with ocular peduncles would have independently developed structures which are so similar in position and function. It becomes perfectly plausible to consider that the prostomial peaks represent an evolutionary step that precedes the formation of ocular peduncles. For example, the developed ocular peduncles, such as those of Pontogenia Claparède, 1868 (HUTCHINGS \& McRae, 1993: 310, fig. 52a), could not have arisen in a single step without a precursor. The minute ocular peduncles such as those of Aphrodita terraereginae Haswell, 1883 (Hutchings \& McRae 1993: 310, fig. 25a) could represent an intermediary evolutionary step between prostomial peaks and well developped ocular peduncles. Instead of creating hypothetical structures for the origin of ocular peduncles in Aphroditidae, it is preferable simply to search their closest polynoid relatives (e.g., Lepidonotopodium; Petтiвone 1983, 1984) for plausible structures of similar function and relative position to reach a hypothesis of homology. By character congruence, it is more parsimonious to hypothesize a transformation series going from prostomium without sensitive structures, passing through a stage of prostomial peaks present, and culminating with ocular peduncles, than to accept the alternative scenario: sensory structures absent, present, lost (in the ancestral polynoid of the Aphroditidae), and the reinvention of sensitive structures in the same position as the prostomial peaks.

The absence of ocular peduncles in Aphrodita (Hutchings \& McRae 1993) may represent a loss shared with Ecdysozoa, which would account for their absence in the latter taxon. Nevertheless, as discussed above, homologies between the anterior regions of Polychaeta and Ecdysozoa need further study.

The definition of the peristomium is also confusing in Fauchald \& Rouse (1997: 77) because it varies a great deal in shape in adults (or may be restricted to an area surrounding the mouth, or to the roof of the mouth, or lips, or may form one elongated segment). The peristomium is also described as of prototrochal origin (FAUCHALD 1977). In the adults it may be restricted to the epidermal folds (lips) surrounding the mouth (FAuCHALD \& Rouse 1997). They may also be identified as ringshaped (Brinkhurst \& Jamieson 1971; EIbYe-JaCOBSEn 1994). Finally, different degrees of fusion with the prostomium and/or with the first metamere have also been characterized (FAUCHALD \& ROUSE 1997).

The problem may lie in the notion that everything that is situated in a prototrochal region should be non-metameric (GILPIN-BROwn 1958). The example of the first pair of tentacular cirri may be illuminating. These structures are identical to the remaining tentacular cirri (OrRHAGE 1993). However, because of their prototrochal embryonic origin they have for a long time been interpreted as pre-segmental structures (SCHRÖDER \& Hermans 1975: 161). But if segmental structures, and consequently representing the first metamere, can change positions during embryonic development, as appears to be the case of the second tentacular cirri pair of Nereididae (GILPIN-BRown 1958), then the apodous rings in this group and many Eunicidae, Sedentaria Audouin \& Milne Edwards, 1833 and Clitellata (Figs 4 and 5), considered to be peristomial, may actually represent cephalized metameres. This would explain why peristomial lips "strangely" simulate apodous metameres (in the form of the rings).

The idea that embryonic regions would be static and immutable during development is not new. For example, until recently the differences among embryological fate maps for several phyla have been taken as evidences for the polyphyletic origins of the Metazoa (ANDERSON 1982). Collazo \& Fraser (1996) and Collazo (2000) have stressed, however, that embryological variations are expected during the development of any individual. In their words, "evolution depends on genotypic variation to proceed". Thus, valid characters form dynamic spectra of particular semaphoronts. The first tentacular cirri in Nereididae, although having neither chaetae nor parapodia, should not be interpreted as non-metameric. Comparatively the development of other tentacular cirri show ventral ganglia, parapodia, and chaetae that are lost and the appendages move forwards, fusing with the mouth region (GILPIN-BROwN 1958; SCHRÖDER \& HERMANS 1975). The first pair of tentacular cirri of the Nereididae should be a step towards total cephalization from a state similar to other tentacular cirri. Hence, the peristomium is homologized exclusively with the peristomial lips (Tab. I, \#11), which is not the same as considering rings or segments to be cephalized. The peristomium structure must represent a synapomorphy for all metamerians. The peristomial 
labiae become subsequently hypertrophied in Eunicidae and Onuphidae. Tentacular cirri, as mentioned above, must be referred to as cephalized appendages of metameric origin.

In Ecdysozoa there is apparently no structure equivalent to the peristomium. Nevertheless, Xenusion auerswaldae Pompeckj, 1927 has the buccal region surrounded by papillae (Dzik \& Krumbiegel 1989). These may correspond to the peristomial labiae or even to the buccal papillae of the Polychaeta. Because there is no strong evidence for this homology, this characters was coded with a "?" for the Ecdysozoa.

\section{Prostomial and peristomial appendages: palps and lophophores}

There has been much uncertainty regarding the homology of the cephalic appendages of Polychaeta. The palps of Nephtyidae Grube, 1850 were considered to be an extra pair of antennae (see FAUCHALD 1977), or the presence of sensory palps were believed to be restricted to the Nereidoidea George \& Hartman-Schröder, 1985 (Glasby 1993). Much of this confusion has been clarified by anatomical investigations of the cerebral nerves (ORRHAGe 1966, 1974, 1978, 1980, 1990, 1991, 1993, 1995, 1996; PurschKe 1993).

From these studies it has been recognized that all palps are homologous structures (Tab. I, \#12). Contrary to Rouse \& FAUCHALD (1997), optimization analyses show that the sensitive, ventral position of these organs shall represent the plesiomorphic condition (Tab. I, \#13). The presence of ventrolateral palps in Eunicida must represent an intermediary state in relation to the grooved feeding palps of the Spionida. Long and robust sensitive palps are a synapomorphy of the scale worms (Tab. I, \#14). On the other hand, stout palps and biarticulated palps (Tab. I, \#15, \#16) are interpreted here as autapomorphies respectively of Phyllodocidae and Nereididae. The subsequent state of this series is represented by the ventrolateral palps beginning in the Nephtyidae (Fig. 4).

Grooved palps with the functions of feeding and respiration (Tab. I, \#17, \#18) represent a strong synapomorphy of the sedentarians, associated with a radical change in their mode of life. The palps of Dorvilleidae, despite not having a ciliated groove as in Spionida, Terebellida, and Serpulida, must represent a step immediately preceding the grooved palps, considering their shape and relative size. There is no great obstacles to this proposal of homology, because Magelonidae (here included in Spionida), also do not have a ciliated groove in their palps.

Losses of palps occur several times in Metameria in connection with habitat shifts. This should not appear suspicious. In several groups in which palps are already absent (Scalibregmatidae and Paraonidae), there are still clear indications of vestigial inervation of these palps (ORRHAGE 1966, 1993). The inverse hypothesis, that the presence of nerves is a previous condition to the occurrence of palps, is not feasible, because the innervation found in Scalibregmatidae and Paraonidae do not innervate particular prostomial structures. This inervation becomes completely lost in the Clitellata. PurschKe et al. (1993) recognize that these losses of the prostomial appendages represented an autapomorphy for the Clitellata (PURSCHKE et al.,2000). Stout and articulated palps become a nested synapomorphy of the Nereididae Johnston, 1865 and Pilargidae Saint-Joseph, 1899 (Figs 4 and 5).
Due to hypotheses of primary homology and to character congruence, short and non-articulate prostomial antennae must be present in the groundplan of the Metameria (Tab. I, \#19). These antennae change their position from frontal to occipital in the Eunicida. They may be reduced to occipital papillae in many specialized groups such as the Eunicidae, or may be totally absent in others, such as the Myzostomidae, Ichthyotomidae, Hartmaniellidae, and Aeolosomatidae. Prostomial antennae are also absent in Sabellida, Terebellida, Owenia, and the Enterocoela (the basal group of which are the pogonophorans having a prostomium without antenna, see Christoffersen \& AraúJo-DE-Almeida 1994) (Figs 4 and 5).

The median antenna does not have the same generality as the lateral antennae (Tab. I, \#20). This structure is absent in the outgroup and in the most basal taxa of Paralacydoniidae, Glyceridae, Goniadidae, Pisionidae, and Nereididae, for example.

A possible homology between the cephalic appendages of Polychaeta and the mesocoelic appendages of Enterocoela is still controversial. They have a prostomial origin in most polychaetes (FAUCHALD 1977), while they originate from the "peristomium" (or mesocoelic region) in the phoronids (SALVINIPLAWEN 1982). The first pair of tentacular cirri in Nereididae is also peristomial, having a similar inervation pattern to the prostomial appendages of other polychaetes (BLAKE 1975; GLASBY 1993; OrRHAGe 1993). In other words, the first somite of Nereididae was added to the cephalic region, appearing connected to the peristomium already in the embryo. Maybe a similar embryonic shift in position has also occurred from the prostomial palps of Pogonophora to the peristomial (mesocoelic) lophophores of the Radialia Ax, 1989. Actually, the entire transformation series involved in the shift from an errant to a burrowing mode, and then to a tubicolous habit is related to a gradual reduction of the posterior parapodia and a parallel development of the anterior appendages in the cephalic region. Hence, the lophophore appears to be homologous to the well-developed tentacles seen in the Sabellida and in Owenia.

Comparing the cephalic region of polychaetes with the basal groups of Ecdysozoa is still more difficult. The lobopod Cambrian fossils Xenusion Pompeckj, 1927, Hallucigenia Conway Morris, 1977, and Microdyction Bengtson, Matthews \& Missarzhevsky, 1981, Onychodictyon Hou, Ramsköld \& Bergström, 1991, for example, have no cephalic appendages. Aphrodita does not have lateral antennae, but still has a rudimentary median antenna (Hutchings \& MCRAe 1993). This indicates that these antennae are gradually lost in this lineage. We thus interpret the prostomial antennae as being reduced in Aphrodita and lost in Ecdysozoa. In fact, there is little support for the presence of prostomial antennae in ecdysozoan lineages.

The cephalic palps may also have been lost in the Ecdysozoa, although these structures still appear to be well developed in scale worms. In another Cambrian lobopod, Kerigmachela, however, there are two frontal tentacles (BUDD 1993 ) that could represent modified palps (Almeida \& CHristofFERSEN 2000: 43).

Although these suggestions of secondary reductions of cephalic appendages sound speculative, they may be less farfetched than trying to establish homologies between such distant structures as the palps of Aphrodita and the first pair of antennae in Crustacea. 


\section{Parapodia and lobopodia: homologous locomotory appendages}

Parapodia are extensions of the body wall functioning in locomotion and for protection (Fauchald 1974; Pettibone 1982; BRUSCA \& BRUSCA 1990). The appearance of parapodia in animal evolution may be related to the development of the mesenteric septa and of the ventral ganglia. As a result of these innovations we obtain a functional complex that includes blood irrigation and the nervous control of parapodial muscles (Bonick et al. 1976; WestheIDE 1997). These correlations are corroborated by the congruence of all these individual characters in the present analyses.

The most generalized parapodium in our analysis has a neuropodium more developed than the notopodium ("projecting neuropodia") (Tab. I, \#21). This condition occurs in most of our basal groups of Metameria. It had been expected that a basal parapodium similar to that hypothesized by FAUCHALD (1974) would be found, in which both notopodia (Tab. 1, \#22) and neuropodia (Tab. 1, \#23) were equally developed. This opinion turned out to be equivocated, however, since such symmetrical parapodia are only found in Nephtyidae and Amphinomidae. Equal rami of the parapodia thus become a convergence in Nephtyidae and Amphinomidae.

Among polychaetes, the scale worms (e.g., Harmothoe Kinberg, 1855, Lepidonotus Leach, 1816, and Aphrodita) have the most efficient parapodia for locomotion (Меттам 1971: 510). While most 'errant polychaetes' depend on lateral undulations of the body for the functioning of their parapodia, Aphrodita use only the parapodia for movement (Меттам 1971: 512) (Tab. I, \#24). Furthermore, Aphrodita also develops a series of diagonal parapodial muscles, which dramatically increase the muscular complexity of these parapodia (SтоRсн 1968; Mettam 1971; Pilato 1981). Almeida \& Christoffersen (2000) argumented these characters are possibly synapomorphies shared by Aphrodita and Ecdysozoa (Fig. 6). They demonstrated that Manton $(1952,1967,1969,1973$, and 1977) based her arguments for the homology of lobopodia and arthropodia on the presence of these new diagonal muscles (Sтовсн 1968; Metтam 1971; Pilato 1981). Arguments of Manton against the homology of parapodia and lobopodia were based on the supposed absence of these muscles in Polychaeta (MANTON 1967: 11). The muscle structure of the parapodia of the Aphrodita shows that the main argument used to criticize the derivation of Arthropoda from Polychaeta is based on incorrect premises (Almeida \& Christoffersen 2000).

In proposals suggesting the derivation of arthropodia from parapodia (Walton 1927; Sharov 1966; LaUterbaCH 1978) the notopodia of polychaetes are homologous to the exopodites of arthropods, and the neuropodia are homologous to the endopodites. The matter regarding which lobopodians represent the most basal ecdysozoans is still unresolved. If forms with biramous appendages such as Kerygmachela (BUDD 1993) turn out to be most basal, no changes in our scheme should be necessary. On the other hand, if uniramous forms such as Xenusion auerswaldae turn out to be most basal (BUDD 1996), it would become necessary to consider that only the neuropodium is homologous to the lobopodium and arthropodium. In this case the biramous condition found in different lobopodian and arthropod clades would not be homologous. BUDD (1996) sustains this last scenario for his phylogeny of the lobopodians. However, in order to make sense

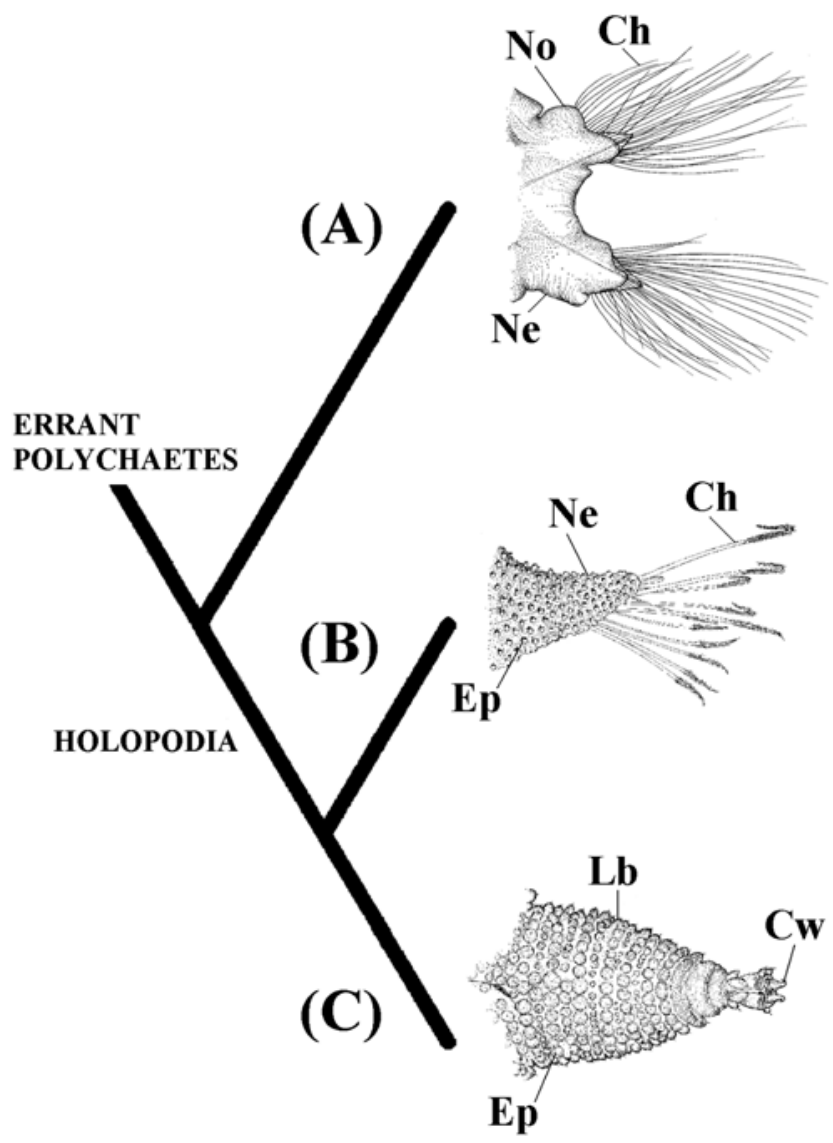

Figure 6. Hypothesis of Almeida \& Christoffersen (2000) with main synapomorphies of the Holopodia (Aphrodita + Ecdysozoa). (A) Errant polychaetes represented by parapodia of Aglaophamus gippslandicus (Nephtyidae) (modified from IMAIIMA \& TAKEDA, 1985); (B) Aphrodita represented by neuropodia of Aphrodita aculeata Linnaeus, 1761 (modified from HarTMAN 1965); (C) Ecdysozoa represented by lobopod of Peripatus sp. (modified from HARMER et al. 1997). Ch, chaetae; CW, claws; Ep, epidermal papillae; Lb, lobopod; Ne, neuropodia; No, notopodia.

of these two conflicting hypotheses, if the homology between elytrae and dorsal plates is accepted, it would be necessary to sustain that the ancestral ecdysozoan was uniramous and armored, the opposite of what BudD (1996) suggested. The resolution of these problems requires a joint analysis of the phylogeny of the Ecdysozoa with the Lobopodia.

ZRZAVÝ \& STYs (1995) provided other arguments against the homology of parapodia and arthropodia. They analyzed the expression of gene en (related to the expression of parapodia and arthropodia) and $w g$ (related only to arthropodia). As already considered in Almeida \& Christoffersen (2000), there are disagreements with the conclusions of ZRZAVÝ \& STYS (1995). Despite detecting differences among taxa, these authors did not prove that parapodia and arthropodia have a nonhomologous genetic basis. More recent molecular data 
presented by PANGaniban et al. (1997) show that arthropodia and parapodia share the same genetic expression for the gene Distal-less (Dll). Even so, Panganiban et al. (1997) do not propose the homology of parapodia with arthropodia, supposedly because of the contrary opinions of FIeLD et al. (1988) and WinNEPENNINCKX et al. (1995). As discussed above, sequence data have an inferior heuristic value in relation to data that correlate genes with phenotypes.

The homology between parapodia of polychaetes and chaetal bundles of oligochaetes has also been a matter of some questioning. According to BRINKHURST (1984a), the arrangement of chaetae into dorso-lateral and ventro-lateral bundles is the most efficient disposition for burrowing and should be considered the most derived state. In this scenario the most basal annelid should have the body entirely surrounded by chaetae. This pattern would be congruent with the pattern of spicules and hooks present in aplacophoran molluscs (Haszrrunar 1992; SCheltema et al. 1994) and sipunculans (StePhen \& EDMUNDS 1972; Rice 1993; CuTLER 1994). Unfortunately for this hypothesis, chaetae surrounding the body are only found in derived forms of terrestrial Oligochaeta. TIMM (1981) indicates that groups such as Haplotaxidae Michaelsen, 1900 and Tubificinae Eisen, 1879, in which the chaetal bundles should be vestiges of parapodia, represent the basal forms of Clitellata. The basal groups of oligochaetes indicated by the analysis of BRinKHURST (1971, 1982, 1984a, b, 1988, 1989, 1991a, b, 1992 a, b, 1994), BrinKhurst \& Nemec (1987), and Omodeo (1998) all have dorso-lateral and ventro-lateral chaetal bundles. Such chaetal bundles do not occur in the burrowing outgroups of the Metameria (Sipuncula and Mollusca), and thus do not appear to be "advantageous" for excavation after all, as suggested by BRINKHURST (1984a). Consequently, there are no real obstacles for considering parapodia of polychaetes and chaetal bundles of clitellates as homologous structures. A likely candidate for the closest outgroup of the Clitellata, the Questidae also has parapodia considerably reduced as a consequence of their burrowing habit. Chaetal bundles are inferred to represent one more successive character state in the evolution towards fossorial habitats, which began in lineages of marine polychaetes and culminated in the conquest of land in some lineages of clitellates. In other burrowing and tubicolous polychaetes (scolecids and Spionida), the parapodia are also reduced when compared to those found in the errant polychaetes. The transformation series affecting parapodia may be ordered from (1) projecting parapodia, to (2) spioniform parapodia, to (3) parapodia reduced to tori (which includes Pogonophora, the most basal group of Enterocoela) (Christoffersen \& Araújo-De-Almeida 1994) to (4) the exclusive presence of chaetal bundles in the scolecids and clitellates (originally in two pairs per segment) (Fig. 5). All these states represent successive stages in the conquest of a sedentary way of life and then of continental environments.

\section{Parapodial cirri, parapodial branchiae, elytrae, and lobopodian dorsal plates}

Parapodial cirri are structures fundamentally involved in sensory functions (Pettibone 1982). Both dorsal (Tab. I, \#25) and ventral cirri (Tab. I, \#26) are quite generally distributed in the Metameria. It is hypothesized that they were already present in the basal plan of this taxon, and their presence in glycerids gives additional support to this point of view.
Sometimes the evolution of the parapodial cirri may occur by parallel transformation series. For example, in several lineages of the Phyllodocidae, both dorsal and ventral cirri may change independently from a filiform to a foliaceous shape (Rouse \& Fauchald 1997). In most cases, however, these structures suffer distinct transformations in different lineages of metamerians.

The ventral cirri are morphologically more conservative. They are usually cirriform, independently of the shape of the dorsal cirri (e.g., in scale worms). Only occasionally does their shape vary, becoming foliaceous (e.g., Phyllodoce Savigny, 1818 in Phyllodocidae), or papillated (e.g., in Sphaerodorum Örsted, 1843, herein included in Syllidae). The presence or absence of ventral cirri is also observed to be quite independent of the presence or absence of dorsal cirri. The absence of ventral cirri is the most frequent apomorphic condition in our analysis. They are independently lost in some internal clades of pelagic and interstitial taxa (e.g., Tomopteridae Johnston, 1865 and Dinophilus Schmidt, 1848), and they are absent in nearly all groups of Sedentaria (e.g., Spionida, Capitellidae, and Questidae) (Fauchald 1977; Pettibone 1982; Fauchald \& Rouse 1997).

The dorsal cirri are more variable in shape. Besides presenting the cirriform and foliaceous shapes mentioned above for the ventral cirri, they may also appear in the shape of elytrae or parapodial gills. MACKIE \& CHAMBERs (1990) did not accept the homology between elytrae and parapodial gills in Sigalionidea. They considered the elytrae to be modified dorsal tubercles. But like Rouse \& Fauchald (1997), these dorsal tubercles are here recognized as another modification of the dorsal cirri. More precisely, the dorsal tubercles must represent diverticula of the dorsal cirri. Furthermore, dorsal tubercles and elytrae never occur in addition to the dorsal cirri in scale worms, while all three mentioned structures occupy similar positions and develop similarly (Day 1967; Fauchald 1977; Pettibone 1982; FAUCHALD \& Rouse 1997). All these observations corroborate the hypothesis that these differently named structures are in fact homologous.

In several Cambrian lobopodian fossils (Xenusion, Onychodictyon, Hallucigenia, Microdictyon) (BuDD 1996) dorsal plates that are similar in form and position to the elytrae of the scale worms have been found. This suggested homology is congruent with the proposed homology between the parapodia of Aphrodita and the arthropodia of Ecdysozoa (AlmEIDA \& Christoffersen 2000). The presence of dorsal plates would place the Cambrian lobopodians in a basal position relative to Ecdysozoa. Budd (1996) considered dorsal plates to be an autapomorphy for his clade Armata Budd, 1996 (Xenusion, Onychodictyon, Hallucigenia, and Microdictyon). Placing Aphrodita as the sister group of Ecdysozoa makes the dorsal plates symplesiomorphic for those fossils. If the homology of elytrae with dorsal plates is accepted, these structures will represent a synapomorphy for all representatives of Holopodia (Aphrodita + Ecdysozoa), and the presence of dorsal plates should no longer be restricted to the Cambrian lobopodians.

Parapodial gills may represent diverticula of the dorsal cirri (e.g., Eunicidae and Onuphidae), or may even represent the entire dorsal cirri (e.g., Spionidae) (Almeida \& Christoffersen 2000: 48 and Fig. 14). However, such structural and functional changes of the dorsal cirri have occurred homoplastically in several different in-group lineages of the Glyceridae, scale 
worms, and Nereididae. Notwithstanding, in agreement with Fauchald \& Rouse (1997), Rouse \& Fauchald (1997), and Pleijel \& DAHLGRen (1998), parapodial gills found in eunicids are considered synapomorphic for the members of this group. This is indicated by their structural and positional similarities in the group, and by their congruence with another character.

The present results also agree with Fauchald \& Rouse (1997) and Rouse \& FAUCHALD (1997) in that the intra-parapodial gills of the Nephtyidae are not homologous to the parapodial gills of eunicids, due to their distinct position and mainly because both dorsal cirri and parapodial gills may occur together in a same animal.

The dorsal and ventral cirri of the first segment in Phyllodocida became modified into tentacular cirri (Tab. I, \#27). The cephalization of the first metamere occurs in parallel with the modification of these tentacular cirri (Fauchald 1977) (Fig. 4 ). This cephalization process of the first metamere may be total, in which the parapodial structures (neuropodia, notopodia, and chaetae) are suppressed, except for the tentacular cirri. The incorporation of the first metamere may occur in such a way that the tentacular cirri of this segment may develop from the peristomium in the larvae, as in Nereididae (see ORRHAGE 1993). Further anterior segments may be added to the head (Day 1967; Fauchald 1977; Glasby 1993). Consequently, each pair of tentacular cirri must correspond to a cephalized metamere.

Even though Eibye-Jacobsen (1994) identified the two anterior rings of Eunicidae and Onuphidae as peristomial (Fig. 4), the possibility cannot be completely eliminated that the "peristomial cirri" of these taxa may be homologous to the tentacular cirri of the phyllodocidens. The first tentacular cirri of Nereididae and the palps of Spionida are peristomial in position throughout development, but their inervation is clearly metameric (ORRHAGE 1964, 1966, 1974, 1993). A similar positional displacement could also have occurred in Eunicidae and Onuphidae. Although tentacular cirri are present in scale worms, there is no indication of the occurrence of these structures in Ecdysozoa. The loss of the cirri, hence, is an obvious ecdysozoan synapomorphy. In their most plesiomorphic state, parapodial cirri must function as sensorytactile devices in raptorial forms, for the capture of prey in association with the functioning of the pharyngeal mandibles (PetTibone 1982; Brusca \& Brusca 1990). The transformation of dorsal cirri into gills and the loss of ventral cirri must be the result of adaptive selection for a sedentary habit. Neither Owenia nor Questidae have dorsal or ventral cirri (Fig. 5). That leads to the possibility that cirri are also lost in Enterocoela and Clitellata. Once again, the mere absence of these polychaetoid structures should not be used to exclude $a$ priori the Enterocoela and the Clitellata from from the remaining metameric animals.

\section{Capillary and compound chaetae, hooded hooks, and uncini in Metameria}

All chaetae present in metamerian groups are considered to be homologous (Tab. I, \#28), including the falcate hooks of Echiura (which are also shared with the Myzostomida) (JäGERSTEN 1936; STEPHen \& Edmonds 1972; Gustus \& Cloney 1972; Specht 1988). The most frequent type of chaeta in the Metameria is the simple or the capillary chaeta. These may become modified either into compound chaetae (e.g., Glyceridae, Nephtyidae, Phyllodocidae, and Dorvilleidae) or uncini (Terebellida and Sabellida). As with most other characters, the chaetae are lost in several specialized groups (e.g., Poeobiidae, Polygordiidae, Histriobdellidae, and Diurodrilidae). All chaetae are formed by $\beta$-chitin (Nielsen 1995), although Amphinomidae and Euphrosinidae have their chaetae impregnated by calcium carbonate (Gustafson 1930) (Tab. I, \#29). This later modification represents a synapomorphy for these two taxa (Rouse \& Fauchald 1997; Pleijel \& Dahlgren 1998; Almeida \& Christoffersen 2000).

Fine silky chaetae are found in Acoetidae (including Polynoidea) and Aphroditidae (partially included within Polynoidea) (Рettibone 1989; Hutchings \& McRae 1993). Long and delicate chaetae, although not involved in the formation of the felt, as in Aphroditidae, are also found in Polynoidae (included in Polynoidea) (see DAY 1967). There are no indications of chaetae for Ecdysozoa. This character was thus coded with a "?" for the Ecdysozoa and restricted the loss of the compound chaetae to form a synapomorphy for the Polynoidea (actually this character produces at least one homoplasy because it occurrs in other taxa such as the Clitellata).

Bartolomaeus (1995), Meyer \& Bartolomaeus (1996), Bartolomaeus \& Meyer (1997), Hausen \& Bartolomaeus (1998), and SCHWEIGKOFler et al. (1998) provide strong evidence for the homology between the neuropodial chaetae (uncini) of some tubicolous forms, like terebellids, sabellids and enterocoels, with other types of hooked chaetae. Like the remaining types of chaetae, the uncini are also formed within chaetal follicles, which are distributed in transversal rows along the neuropodial rim (BARTOLOMAEus 1995). Such follicles consist of two cells and a chaetoblast, whose bands of microvilli give rise to the teeth and the shaft of the uncinus. The curved pattern of the teeth of these hooked chaetae in oweniids, arenicolids, capitellids and spionids is the result of a reorientation of the longitudinal axis of the microvilli of the chaetoblast during chaetogenesis (Meyer \& Bartolomaeus 1996) and must have originated more than once in the group.

The uncini are sometimes distinguished from other hooked chaetae (Tab. 1,31 ) because the former has a very short shaft, whereas the latter possess long-shafted columnar structures. According to BarTOLOMAEUs (1995), the uncinal chaetae may also be characterized by the fact that the microvilli of their chaetoblasts are completely withdrawn by the end of chaetogenesis, being replaced by short processes from the chaetoblast, that keep the uncinus attached to the follicle. Furthermore, the uncini are exposed in their follicles when completely formed. Hooked setae, on the other hand, arise from the epidermis before chaetogenesis is completed (Bartolomaeus \& Meyer 1997).

Meyer \& Bartolomaeus (1996) pointed out that neuropodial hooked chaetae in members of Owenia do not possess structures that can be homologized to the rostrum of the uncini, as interpreted by Nielsen \& Holthe (1985). However, the different number of microvilli involved in the formation of both rostrum and capitulum does not necessarily refute a hypothesis of homology between the groups of teeth of hooked chaetae and uncini. This opinion was mainted here despite the fact that Meyer \& Bartolomaeus (1996) provided evidence for a distinct mode of chaetogenesis of the hooked chaetae in Owenia. Again, differences per se are insufficient to refute hypotheses of homology. 
Unpublished data on the chaetogenesis of the chaetopterid uncini demonstrates that this process fits well with descriptions of chaetal development in sabellids and terebellids (BARTOLOMAeus pers. comm.). Gupta \& LitTle (1970), Orrhage (1973b), Bartolomaeus (1995), and Meyer \& BARTOLOMAEUs (1996) have been followed in the assumption that the uncini of pogonophorans are homologous to the uncini of other tubicolous polychaetes. The similarities extend to general morphology, disposition on segments (forming transverse rows) and site of formation. Although the presence of uncini represents a synapomorphy positioning Pogonophora among the sabellids at a more restricted hierarchical level, it must be stressed that this character represents a symplesiomorphy for the internal groups of Enterocoela (ChristofFerSEN \& ARAúJO-DE-AlmeIDA 1994). This character should not be considered a valid difference separating the deuterostomes from the protostomes. The opisthosome of Pogonophora is non-informative for deuterostome phylogeny, in the same way that ovoviparity in monotremes is not informative for the phylogeny of mammals. If this hypothesis of the homology of uncini is correct, the intriguing occurrence of polychaete-like chaetae in brachiopods (Gustus \& CloneY 1972) could represent a case of evolutionary reversion (genetic atavism).

Unicini were considered specialized chaetae, though it is not possible at this time to point out with certainty from which kind of hooked setae they are derived. The spioniform groups present different kinds of hooked chaetae, some of which are very similar to those seen in the neuropodia of Owenia (Nielsen \& Holthe 1985).

The so-called 'chaetal inversion', as well as modifications in the shapes of the parapodial rami, occurs near the transition between thoracic and abdominal regions of Sabellariidae and Sabellidae (Dales 1952; Fitzhugh 1989; Fauchald \& Rouse 1997). The notopodia of the thoracic region in these groups carry capillary chaetae and neuropodial uncini, whereas the abdominal region exhibits capillary chaetae in the neuropodia and uncini in the notopodia (FITZHUGH 1989; Fauchald \& Rouse 1997). This phenomenon is not observed in terebellids and chaetopterids, in which uncini are also present (see description of their parapodia in FAUCHALD 1977). Apparently no evidence of this pattern has been found in Pogonophora. As further evidence for the lack of chaetal inversion in the Enterocoela, we mention that in early developmental stages of Ridgeia Jones, 1985 (Vestimentifera Jones, 1985) the opistosomal uncini seem to be restricted to the ventral side of each segment (see SOUTHWARD 1988; Bartolomaeus 1995: 173, for comments on pogonophoran uncini).

Bartolomaeus (1995) and Bartolomaeus \& Meyer (1999) established two different sites for the formation of chaetae in the neuropodial tori. In this first observation, only the Arenicolidae and the Maldanidae were said to have the formative site localized on the ventral edge of the neuropodial rim. On the other hand, in Terebellida, Sabellida, and Pogonophora, such sites were observed on the dorsal edge. This pattern was later confirmed for other families of Polychaeta, namely Oweniidae, Capitellidae, and Spionidae (Meyer \& Bartolomaeus 1996; Hausen \& Bartolomaeus 1998; SChWeigkofler et al. 1998). According to present results, this would suggest that the ventral formative site of hooked chaetae might be a synapomorphy of Arenicolidae + Maldanidae (BARTOLOMAEUs \&
Meyer 1999). This would be a reliable hypothesis: (1) because this monophylum is a derived group within the sedentary polychaetes; and (2) due to the more basal position of Spionida within the Sedentaria in the present study. However, ultrastructural examinations of the neuropodial formative sites are also necessary for other families of polychaetes, in order either to confirm the ventral formative site as a synapomorphy of the Arenicolidae+Maldanidae, or to verify whether the ventral formative site may have derived from the dorsal one. Thus, this particular character has not been used in the present analyses.

Our interpretation of the acicula differs from that of Rouse \& Fauchald (1997) in that we consider their presence in Psammodrilidae and Orbiniidae as a primary retention, while we consider their absence from Spionida and the remaining apical taxa as a synapomorphy for the resulting clade Sedentaria.

Capillary and spinous chaetae are undoubtedly homologous to polychaete chaetae (STEPHENSON 1930; COOK 1971). Consequently, the inclusion of Clitellata among the polychaetes is entirely congruent with this knowledge.

Aciculae and chaetae are absent in Ecdysozoa. However, in some scale worms, from Polynoidea onwards, there has already occurred a loss of compound chaetae. It thus seems plausible to follow this trend through and consider that capillary chaetae and aciculae were further lost at the transition from scale worms to ecdysozoans. The absence of acicula (Tab. I, \#32) is clearly related to the acquisition of new apodemes for muscular attachment. The beginnings of this new arrangement may already be observed in Aphrodita, in which the muscles are much more complex for vigorous movements of the parapodia (Storch 1968; Metтam 1971; Pilato 1981). The plesiomorphic function of chaetae for the movement of errant worms has evidently been superseded by the novel mode of locomotion by articulated appendages in arthropods.

\section{Pygidial cirri}

Pygidial cirri (Tab. I, \#33) are sensory-structures usually similar to parapodial cirri (Fauchald 1977; Pettibone 1982). Most of their variations in number and shape are restricted to internal clades not studied herein (e.g., Cossuridae, Polygordiidae, Saccocirridae). A single pygidial cirrus represents an autapomorphy of Nephtyidae (DAY 1967), and additional peglike appendages are autapomorphic for Eunicidae (FAUCHALD 1992a, b). A single pair of pygidial cirri must be synapomorphic for all Metameria.

There is no evidence of the occurrence of these structures in Enterocoela and Clitellata, neither in their respective sister groups, Owenia and Questidae (Nielsen \& Holthe 1985; Giere \& ERséus 1998). In Ecdysozoa, pygidial cirri are also absent from both Cambrian lobopods and recent Onychophora. Almeida \& CHRISTOFFERSEN (2000: 43) tentatively interpreted the posterior pair of tentacles in Kerigmachela as pygidial cirri. Similar homology relations with the higher enterocoelans require a dorso-ventral inversion of the nervous system, a hypothesis that is becoming increasingly accepted with molecular and ontogenetic evidence (Nübler-Jung \& ARENDT 1994, 1999; ARENDT \& NüBler-Jung 1994, 1997, 1999). This tends to dissipate the objections of ORRHAGE (1973a) for the existence of an annelidlike ancestor for the deuterostomes. Even so, the nervous system of the Pogonophora is similar to that found in the Enterop- 
neusta and remaining lophophorates (SOUTHWARD 1993: 360366; Christoffersen \& AraúJo-De-Almeida 1994: 189; Salvini-Plawen 2000: 140).

\section{Cuticle}

Rouse \& Fauchald (1995) indicated that the cuticle of annelids (Tab. I, \#34) is composed of collagen (see also Gustavsson \& Erséus 2000). However, that their chaetae are composed of chitin. Annelids have $\beta$-chitin, while ecdysozoans usually have $\alpha$-chitin. However, $\beta$-chitin has been reported also in Pentastomida (Karuppaswamy 1977; but see Delle Cave et al. 1998), an ecdysozoan of problematical position with a fossil record overlapping that of the Cambrian lobopods (Walossek et al. 1994; Walossek \& Müller 1994; see also Almeida \& Christoffersen 1999 FOR PHYLOGENETIC EXPLANations about the positions of these fossils). This seems to indicate to us that despite the differences in composition between $\alpha$-chitin and $\beta$-chitin, these must derive from a same genetic pool. The presence of chitin in the cuticle must be a synapomorphy for all Metameria, $\beta$-chitin being the groundplan condition. The reappearance of $\beta$-chitin in the pentastomid ecdysozoan, like the reappearance of chitinous chaetae in the brachiopod enterocoel (GUSTUS \& CLONEY 1972), may represent another case of genetic atavism.

Epidermic papillae are common in several polychaete lineages, e.g., in Aphrodita (Pettibone 1966; Watson Russell 1989; Hutchings \& McRae 1993; Chambers \& Muir 1997) (Tab. I, \#35). Similar structures occur in the Cambrian lobopode Xenusion (DzIK \& KRUMBiEgel 1989). In recent Onychophora these papillae are strongly decorated (Harmer et al. 1997). Despite some differences in shape and development, all these epidermal rugosities may be homologous (Fig. 6).

\section{Nervous system}

The nervous system of Platyhelminthes, Nemertea, Mollusca, and Sipuncula has non-ganglionated ventral nerve cords. The circumpharyngeal connectives (Tab. I, \#36) could represent a synapomorphy uniting the supra-pharyngeal ganglion to the ventral nerve cords in Nemertea, Mollusca, Sipuncula, and Metameria (Hyman 1951, 1959; BRUSCA \& BRUSCA 1990). Metameric ganglia (Tab. I, \#37) evolved together with parapodia and their presence is a synapomorphy of metameric animals. Their presence in animals without septae and without appendages, such as Rotifera (NIELSEN 1995) indicates that these animals are derived from metameric animals that had appendages.

There are no great problems in establishing relations of homology among the nervous systems of Polychaeta, Clitellata, and Ecdysozoa. This interpretation has been held since CuvieR (1812) established the taxon Articulata. Similar homology relations with the higher enterocoelans require a dorso-ventral inversion of the nervous system, a hypothesis that is becoming increasingly accepted with molecular and ontogenetic evidence (Nübler-Jung \& ARENDT 1994, 1999; ARENDT \& NÜbler-Jung 1994, $1997,1999)$. This tends to dissipate the objections of OrRHAGE (1973a) for the existence of an annelid-like ancestor for the deuterostomes. Even so, the nervous system of the Pogonophora is similar to that found in the Enteropneusta and remaining lophophorates (SOUTHWARD 1993: 360-366; Christoffersen \& Araújo-de-Almeida 1994: 189; Salvini-Plawen 2000: 140).

\section{Nuchal organs are a synapomorphy of metamerians}

Nuchal organs (Tab. I, \#38) may be provisionally interpreted as synapomorphic for metameric animals. Sensory organs in a similar position are found in Sipuncula (BRUSCA \& BRUSCA 1990) and Nemertea (hyman 1951). Turbeville (1991), Rice (1993) and Rouse \& Fauchald $(1995,1997)$ indicate structural and inervation differences among these sensory organs when compared to polychaete nuchal organs. Despite such differences, the possibility always remains that these cephalic sensory structures may represent a synapomorphy of coelomates.

Following Rouse \& Fauchald (1997) and Pleijel \& Dahlgren (1998), present results suggest that the modification of nuchal organs into caruncles (Tab. I, \#39) could rerpesent synapomorphic conditions uniting Amphinomidae Savigny, 1818 and Euphrosinidae Williams, 1851. On the other hand, there are strong indications that the absence of nuchal organs in Clitellata is secondary (Fig. 1). Some of this evidence is direct. It derives from the ontogeny of the cerebral ganglia (Hessuing \& Westheide 1999) and from the congruence with other characters (Fig. 1). Other evidence is indirect. Similar losses occur in the terrestrial polychaetes (PURSCHKE 1997, 1999; PURSCHKE et al. 2000). And when the taxon Questidae is accepted as closely related to the clitellate lineage based on the presence of a clitellum, it may be deduced that the polychaete-like ancestor of the Clitellata had nuchal organs.

There is no information about the presence or absence of nuchal organs in the Pogonophora and other Enterocoela. On the other hand, the absence of nuchal organs in the Ecdysozoa may be related to the gradual sclerotization of the cuticle and to the loss of epidermal cilia (WeygoldT 1986). Due to the nested position of Ecdysozoa within the Metameria given by other characters (Figs 1, 6), the absence of nuchal organs in Ecdysozoa is not itself an argument for discarding a close relationship between polychaete worms and arthropods. Summarizing, polychaetologists are not justified in excluding Clitellata, Enterocoela, and Ecdysozoa from the Polycheata based on the argument that nuchal organs are absent in these groups.

Other ciliated sensory organs are the "lateral organs" (FAuCHALD \& Rouse 1997) (Tab. I, \#40). Although these structures are not widely distributed, the present results point out that they represent a synapomorphy for sedentarians. Losses must have occurred in Maldanidae and Arenicolidae.

\section{The stomodeum and polychaete phylogeny}

The stomodeum (Tab. 1, \#41) has been considered both for polychaete phylogeny and classification (DALEs 1962, 1963). Arguments based on this character have been accepted as decisive to position archiannelids and other lineages of polychaetes (PurschKe 1984, 1985a, b, 1987a, b, 1988b; PURSCHKE \& Jouin 1988; PurSChKE \& TzETLIN 1996). Nevertheless, polarizing character states related to the stomodaeum is difficult. For example, two distinct states, an axial and a ventral proboscis, occur in the Spionida. This led OrRhage (1973a) to reject the phylogenetic proposal of DaLEs $(1962,1963)$. This arrangement only indicates that the Spionida represents a paraphyletic assemblage, in which some groups are more basal and related to the clade (Dorvilleidae + (Onuphidae+Eunicidae)), and other groups are more derived, related to the terebelids and sabellids. Thus a ventral proboscis becomes a synapomorphy for the 
Amphinomidae+Euphrosinidae and the remaining modified groups of the eunicids. The presence of an axial proboscis within this clade would represent the retention of the primitive state. Similarly, the retention of a rudimentary median antenna in some internal groups of the Spionida (e.g., Uncispionidae and Aberrantidae) (GreEN 1982; Wolf 1987) has to be interpreted in this same way. Contrary to Rouse \& Fauchald (1997), the hypertrophied axial proboscis was interpreted as the most plesiomorphic condition for this structure. A simple axial saclike proboscis is interpreted as a derived condition and this corroborates the idea of progressive simplification occurring in the scolecids. On the other hand, in line with the congruence of characters 57-61 (Fig. 1), the unique pharynx of the Clitellata (Cook 1971, and Brusca \& BRusca 1990) is interpreted as a specialization of the sac-like pharynx of the scolecids.

In Pogonophora the digestive system has been occluded in the adult (SOUTHWARD, 1988). There is insufficient information from the first developmental stages of pogonophorans to follow the transition between the polychaete stomodaeum and the enterocoelous pharynx characterized by evaginations in the Pharyngocoela Christoffersen \& Araújo-de-Almeida, 1994, Pharyngotremata Schaeffer, 1987, and Eupharygotremata Christoffersen \& Araújo-de-Almeida, 1994 (Hyman, 1959 Christoffersen \& Araújo-De-Almeida, 1994).

In Ecdysozoa the absence of polychaetoid pharyngeal muscles is related to the process of sclerotization of the cuticle. The formation of apodemes for muscle insertion and the development of new striated muscles for the articulation of exoskeletal plates imply in a complete reorganization of the muscular system (MANTON 1952, 1967, 1969, 1973, 1977). Contrary to Fauchald \& Rouse (1997) and Rouse \& Fauchald (1997), the differences observed in muscle arrangements in polychaetes and arthropods do not constitute valid evidence against any hypothesis of phylogenetic relationship between these two groups.

The pharynx of Syllidae, Nereididae, and Pilargidae has a transversal groove (Tab. I, \#42). This structure must be a synapomorphy uniting these three taxa (Pleijel \& Dahlgren 1998).

The pharynx in many metamerians may contain cuticular specializations such as mandibles and cuticular ridges (Gustafson 1930; Fauchald 1977; Orensanz 1990). Mandibles are very common in the basal groups of Metameria, being related to the raptorial habits of these animals (PеттівоNe 1982). Details about their disposition, number, and shape have been found to be too diverse to be useful at the higher levels that are being dealt with herein. These structures are arranged in circlets in Glyceridae and Goniadidae, for example (Tab. I, \#43), side by side in Nereididae, and have a quadrangular arrangement in Pisionidae Southern, 1914, Sigalionida, and others (Tab. I, \#44). Glyceridae and scale worms have four mandibles, while Nereididae and Pilargidae have two. In Spermosyllis Claparède, 1864 and some other derived syllids, mandibles may be further reduced to one. Finally, Glyceridae have associated cuticular ailerons, Nereididae present interspersed paragnaths, while Eunicidae, Onuphidae, and Dorvilleidae form maxillae and carriers (ÅKESSON 1961; KIELAN-JAWOROWSKA 1966; DAY 1967; Fauchald 1977; Glasby 1993) (Tab. I, \#45). Glasby (1993) rejected the hypothesis of homology among all types of mandible in order to reduce one step in his cladistic analysis. Three characters relating to mandibles were used in the present analyses (Tab. I). It has not been necessary to reject a hypothesis of primary homology among all types of cuticular sclerotizations of the pharynx.

Amphinomidae and Euphrosinidae do not have mandibles. However, the pharynx is strongly sclerotized and has ridges in these taxa (GUSTAFSON 1930) (Tab. I, \#46). Rouse \& Fauchald (1997) and Pleijel \& Dahlgren (1998) have already identified this character as a synapomorphy for these taxa.

Mandibles are secondarily absent in Enterocoela, which correlates with their new feeding habits of ingesting food particles from the substrate or in suspension. This character loss may have occurred even earlier, during the evolution of their tubiculous relatives. This hypothesis is supported by another possible example of genetic atavism in Gnatoampharete Desbruyères, 1978, a terebellid that "mysteriously" presents mandibles (Holthe 1986).

The absence of polychaete-like mandibles in Ecdysozoa is also secondary. In Aphrodita the mandibles are already rudimentary or even absent (Fauchald 1977; PetTibone 1966; WATSON RUSSELL 1989).

The presence of a ventral buccal organ (Tab. I, \#47) in many Sedentaria (PuRschKe 1984, 1985a, b, 1987a, b, 1988a, b) must represent a synapomorphy for the members of this taxon. The pharynges of Clitellata are highly modified. In some taxa the whole digestive tube may be lost (see Enséus 1984). The same is true for the adults of Pogonophora. It can be suggested that the loss of the buccal organ is correlated with the simplification of the digestive tube in the Sedentaria, but this is unsure.

\section{Digestive system: anus}

The terminal opening of the digestive tube was considered in the present analyses to be homologous in nemerteans, molluscs, sipunculids, and metamerians (Tab. I, \#48). There is significant variation in the embryological development of the anus and of the mouth (SAlvini-Plawen 1982). Differences in origin of the mouth and anus have long been used to sustain a dichotomy between Protostomia and Deuterostomia (e.g., Hyman 1951). However, Salvini-Plawen (1982) showed that the deuterostomate pattern derives from the protostome condition. WiLlmer (1990) viewed this character with reserve, although still accepting the dichotomy between Protostomia and Deuterostomia. Christoffersen \& ARAúJo-DEAlmeIDA (1994) indicated the artificiality of this dichotomy for the Metazoa. The hypothesis that considers deuterostomes to be derived from protostome ancestors is becoming increasingly supported by larval, developmental, and molecular data (McGinnis et al. 1984; SMith et al. 1987; LAWREnce 1990; EMLET \& Strathmann 1994; Nübler-Jung \& Arendt 1994, 1999; Arendt \& Nübler-Jung 1994, 1997, 1999; François \& Bier 1995; Holley et al. 1995; Jones \& SMith 1995; Holland et al. 1997).

\section{Fusion of nephridia and gonoducts: transformation series still unreliable}

The present results indicate that metanephridia (Tab. I, \#49) are symplesiomorphic for Metameria. Thus it is more parsimonious to interpret the presence of protonephridia in adults of Glyceridae, Goniadidae, Phyllodocidae, Pisionidae, and Nephtyidae as secondarily derived (Rouse \& FAUCHALD 1995, 1997; Pleijel \& Dahlgren 1998), although there is still insufficient knowledge on nephridial evolution. Protonephridia 
represent a bilaterian synapomorphy, which became restricted to the larvae as a coelomate synapomorphy. It is quite well known that trochophores of mollusks and polychaetes retain protonephridia as juvenile excretory organs, which are lost along the ontogenetic development of the individual, usually being replaced by metanephridia. This means that the adult protonephridia in Metameria corresponds not to a de novo origin of a lost organ, but to the retention in adults of a larval structure. Also, it means that protonephridia are homologous for most metazoan taxa, in which they are present. Apparently, adult protonephridia in metamerians are related to a loss of the excretory function of the metanephridia.

The present results corroborate the traditional idea that multiple nephridia are plesiomorphic in relation to a reduced number of these organs restricted to particular segments (Goodrich 1945). One pair of anterior nephridia (Tab. I, \#50) opening dorsally (Tab. I, \#51) represents a synapomorphy for terebelliform metamerians.

Larval deuterostome-like nephridia in Owenia (SмIтн et al. 1987) (Tab. I, \#52) are considered to represent a synapomorphy of this taxon with Enterocoela. Although such nephridia are not universally present in Enterocoela, our hypothesis of primary homology for this character is based on their presence in the basal plan of the Enterocoela (Christoffersen \& Araújo-de-Almeida 1994).

On the other hand, the various degrees of fusion of nephridia with gonoducts, resulting in protonephromixia, metanephromixia, and mixonephridia, in Goodrich's (1945) terminology, are insufficiently clarified. It is not possible to test such hypotheses of homology only with the use of cladograms (Rouse \& Fauchald 1997: 167). A phylogenetic analysis must evaluate the possible homology existing among empirically elucidated characters. For example, there is some embryological empirical support for the hypothesis that ear bones are derived from gill supports, while such confirmation is absent for the fusion between nephridia and gonoducts. Rouse $\&$ FAUCHALD (1997) use the presence of mesodermic tissue in the nephridia of Arenicola Lamarck, 1801 (Goodrich 1945), Pisione Grube, 1857 (AIYAR \& AlikunHI 1940), and Terebellida and Serpulida (Meyer 1887, 1888, 1901; Sмith 1988) to confirm Goodrich's (1945) ideas. However, Bartolomaeus \& Ax (1992) and Bartolomaeus (1999) indicate that the presence of mesodermal cells of the coelomic lining in the nephridia may contribute to the anlage of the funnel only to a limited extend. But this does not indicate the occurrence of an ancestral fusion between a genital funnel and a nephridial duct. BARTOLOMAEUs (1999: 34) says: "[I never claimed that] the nephridia of annelids are of ectodermal origin, although this has been credited to me in some papers (Bunke 1994; Rouse \& Fauchald 1997)."

If protonephridia can derive from metanephridia (Westheide 1986), or metanephridia from protonephridia (Bartolomaeus 1997; Pleijel \& Dahlgren 1998: fig. 1a), or even protonephromixia from metanephromixia (Rouse \& FAUCHALD 1997: fig. 69), these structures would seem to be very plastic. What the empirical data of Westheide (1986), SMith \& Ruppert (1988) and Bartolomaeus $(1989,1999)$ do indicate is that the expression of either protonephridia or metanephridia depends very intimately on the relative extension of the coelom, despite the disagreement of Rouse \& Fauchald (1997). Furthermore, when the most proximal cell of the nephridial primordium is expressed in phyllodocids, this results in the formation of protonephridia (BARTOLOMAEUs 1999: 35). These protonephridia must be interpreted as secondary formations in accordance with the perspective of Rouse \& Fauchald (1997).

When this pattern of apparent multiple reversions between protonephridia and metanephridia are associated with the hypotheses of multiple types of nephridial fusion with gonoducts (protonephromixia, metanephromixia, and mixonephridia), the possibilities of combinations among these types becomes so large as to become surrealistic. Before polarizing these states into ordered and unordered, linear and ramified, dependant and independent character states, a less scattered and easier to interpret database of empirical information on these structures becomes necessary.

\section{Evolution of the clitellum and the conquest of terrestrial environments}

A cocoon that contains the eggs is produced by the clitellum (BRINKhURST \& JAMIESON 1971) (Tab. I, \#53). This character has always been considered an autapomorphy of the Clitellata. However, in present analyses the glandular area found in the Questidae (GIERE \& RISER 1981; Giere \& Erséus 1998) has been suggested as being homologous to the clitellum. More precisely, the glandular area of Questidae represents the first step in the formation of the fully annular clitellum with the subsequent production of cocoons.

Outside of the Metameria and in most families of polychaetes, the reproductive organs (testicles, ducts, and ovaries) are temporary structures (DAY 1967; FAUCHALD 1977; Pettibone 1982; Fauchald \& Rouse 1997). In the Questidae and all clitellates, on the other hand, the reproductive organs (Tab. I, \#54) are contained in specific segments defined already in the immature stages (BRINKHURST \& JAMIESON 1971; GIERE \& RISER 1981; Giere \& ERSÉUs 1998). The absence of permanent reproductive structures is plesiomorphic (Day 1963; Pettibone 1982; Fauchald 1977; Fauchald \& Rouse 1997). In Questidae and Haplotaxidae (considered to be one of the most basal group of Clitellata; BRINKHURST 1984a) the synapomorphy consists of the presence of two pairs of ovaries in the female reproductive system (BRINKHURST 1982, 1992b) (Tab. I, \#55). The presence of a spermatheca and the opening of the gonoduct in segment 14 found in Questidae and Clitellata (BRINKHURST \& JAMIESON 1971; GIERE \& RISER 1981) must be synapomorphic for these taxa. The absence of gonoducts in segment 14 (Tab. I, \#56, \#57) is secondary within some modified Clitellata, because they are present in the basal clitellates.

The Questidae have a partial clitellum and an oligochaetoid developmental pattern (GIERE \& RISER 1981). Furthermore, of the eleven autapomorphies indicated for the Clitellata (Purschke et al. 1993), seven (hermaphroditism, spermathecae, gonads located in specific segments, clitellum, specific developmental pattern, loss of a trochophore, reduction of the prostomium and loss of the prostomial appendages) are shared with other groups of scolecids. Thus, the process of clitellarization is seen to be gradual within the Metameria (first the reproductive organs become fixed in specific metameres, then a glandular clitellum is gradually formed, and finally there occurs the production of cocoons). The spermatological autapomorphies indicated by JAMIESON (1981) and FERRAGUTI \& ERSÉUs (1999) for the Clitellata must be seen with some skepticism, because, as already discussed in the case of the nuchal organs, they were provided typologically in order to 
distinguish the clitellates from their stem-species, rather than to elucidate their phylogenetic relationships. Furthermore, Parergodrilus heideri and Hrabeiella periglandulata are examples of interstitial and terrestrial polychaetes that have oligochaetoid sperm (KRISTENSEN \& EIBYE-JACOBSEN 1995; Rota \& LUPETTI 1997; RоTA 1998). Questidae may well differ in some of the sperm characteristics from the pattern of the Oligochaeta Grube, 1850 (JAmieson 1983). Yet this constitutes no valid evidence to discard the relations neither between the Clitellata and the Questidae, nor between these two groups and the other scolecids. On the other hand, the large number of morphological and reproductive synapomorphies represents convincing evidence for a close relationship among these groups.

Further sustaining the hypothesis that Clitellata represent a derived group of polychaetes is the indirect evidence presented by Purschke $(1997,1999)$ and Purschre et al. (2000) on the parallel adaptations for land of Clitellata and of other terrestrial polychaetes, and direct evidence regarding the development of the cerebral ganglia in the Clitellata (HessLING \& WestheIDE 1999).

FAUCHALD (1974) has already proposed the hypothesis of a derivation of Clitellata from a scolecid ancestor. NIELSEN (1995) also defended this hypothesis. Mainly because of their hermaphroditism, the capitellids were considered by this author to be closest to the Clitellata. The present results do not support the notion that hermaphroditism would be a strong indication of such a relationship, since this condition is found in other groups (e.g., in some nereidids, syillids, and serpullids; BRUSCA \& BRUSCA 1990). Questidae, even though being still gonochoristic (JAMIESON \& WЕвB 1984), already has gonads restricted to a few segments, and, even more relevantly, has a primordium of a clitellum. The same argumentation above can be used against the suggestion of McHugH (2000: 1879) that Aeolosomatidae is the sister group of Clitellata, even though the proposal seems at first suggestive because aeolosomatids have been previously considered to be oligochaetes and because most of their species are limnic (Тімм 1981, 1987).

Enterocoela has a single pair of gonads that open posteriorly. This condition is shared with Sabellida (GOODRICH 1945). This is congruent with the hypothesis of CHRISTOFFERSEN \& ARAÚJO-DE-AlmeIDA (1994), in which this character represents the initial stage of an extended transformation series affecting the development of gonads through the more apical lineages of Enterocoela (Eupharyngotremata Christoffersen \& Araújode-Almeida, 1994, Cephalata Christoffersen \& Araújo-deAlmeida, 1994, and Vertebrata; Christoffersen \& AraúJo-DeAlmeida 1994).

The permanent gonads of Ecdysozoa do not appear to be homologous to the temporary gonads of aphroditids, because their structure and position are different (BRusCA \& BRUSCA 1990).

\section{Larvae and the origin of the Enterocoela}

The adaptive diversity of larval forms (Tab. I, \#58) found in most Metazoa represents a challenge for the reconstruction of a simple and straightforward phylogenetic pattern. Ontogenetic, morphological and habitat modifications of larval types are found in many different low-level taxa. Reversions of larval types (e.g., from planktotrophic to lecitotrophic, and vice-versa) are also very common (see Strathmann 1978;
Williamson 1987; Wray \& RafF 1991; Rouse \& Fitzhugh 1994; Bhaud \& Duchêne 1996; McHugh \& Rouse 1998; Rouse 1999).

Amongst this diversity, the mitraria larva of Owenia "strangely" presents deuterostome characters, such as monociliary cells, prototroch with parallel bands of cilia, presence of a food groove, metatroch forming sinuous curves, and a deuterostome-like nephridium (Sмiтh et al. 1987; EmLet \& Strathmann 1994) (Tab. I, \#59). Christoffersen \& Araújo-DEAlmeida (1994) have previously identified morphological homologies between the adults (the tagmosis of oweniids appears to be similar to the prosoma, mesosoma, metasoma, and opisthosoma of the Pogonophora). This seems to indicate that the "deuterostome-like anomalies" of larval oweniids (WILSON 1932; GARDINER 1978) represent true homologies linking Owenia with Enterocoela. Even the distinguishing character of a mouth surrounded by the prototroch in the deuterostomes proposed by WILLMER (1990) may be extended to the larvae of Owenia, as the sinuous prototroch may be interpreted as the first step in this direction (Fig. 7). Although Pogonophora (sensu lato including the Vestimentifera) do not have typical larvae, our view is consistent with older theories on the closer affinities of the Pogonophora with the Deuterostomia (Ivanov 1957, 1963; Wевв 1969). The recent consensus for positioning the pogonophorans among the annelids (Rouse \& Fauchald 1995, 1997) is based on plesiomorphic similarities such as the presence of typical metameres and chaetae in the posterior region of the body. Indeed, this approximation of the Pogonophora to the tubiculous polychaetes is not in dispute.

The ancestral trochozoan larva defined by Rouse (1999, 2000) gradually gives rise to the descendant tornaria larva. Both trochophores and tornariae share the presence of a prototroch and this character thus cannot represent a synapomorphy for the Trochozoa.

The larval development of Owenia, which was called catastrophic metamorphosis (WILsON 1932; ANDERSON 1974) (Tab. I, \#60), is very similar to that found in some groups of Enterocoela (e.g., Phoronida; see NielSen 1995). In typical trochophoran larvae, somites are added at the posterior region of the animal one by one, and the larvae transforms into the adult gradually (e.g., Nereididae; see BlAKE 1975). In the mitraria larva the new segments accumulate within the larval hyposphere, until the larvae bursts and all the segments are freed catastrophically. Although in Phoronida and Brachiopoda the segments do not accumulate inside the larvae, there is nevertheless a rapid metamorphosis and a dramatic elongation of the metasoma. A " $U$ "-shaped digestive system results from the shortening of the dorsal side and larval ciliated tentacles are ejected at metamorphosis (NieLSEN 1995).

The downstream ciliary beating of protostomes (NIELSEN 1995) is plesiomorphic in relation to the upstream ciliary beating in deuterostomes.

Recent molecular and developmental data also corroborate a transition from protostomes to deuterostomes (McGinnis et al. 1984; LAwRence 1990; ARENDT \& NÜBler-Jung 1994, 1997, 1999; NÜbler-Jung \& ARendt 1994, 1999; Holland et al. 1997; François \& Bier 1995; Holley et al. 1995; Jones \& SMith 1995; Peterson \& Davidson 2000; Peterson et al. 2000a, b).

The other two major clades, Holopodia (Aphrodita + Ecdysozoa) and Apoclitellata (Questidae + Clitellata) cannot be tested with larval characters, because in both clades development is direct (Thorson 1946; Brusca \& Brusca 1990; 
Wilson 1991; Giangrande 1997). However, there is a possibility that the information on direct development in Aphrodita obtained by THORSON (1946) and retransmitted by WILSON (1991) and GIANGRANDE (1997) may be equivocated because a group of scientists at Helgoland island has recently succeeded in rearing Aphrodita aculeata and have obtained a trochophore larva (WäGELE pers. comm.). If this is confirmed, the presence of direct development must be reinterpreted for a different level of generality, and the character may represent an autapomorphy for Ecdysozoa (in this case direct development would become associated with ecdysis and cuticular sclerotization).

\section{Invalidating the concepts of the Protostomia and Lophotrochozoa Aguinaldo, Turbeville, Linford, Rivera, Garey, Raff \& Lake, 1997}

A major prior question concerning the judgment of the results presented herein relate to one's views about the monophyly of the Protostomia. The present results deny that the Protostomia represent a monophyletic group, with the Deuterostomia as its sister group. And when Protostomia are perceived as invalid, the Lophotrochozoa of AguinaLdo et al. (1997) also becomes an invalid by-product of the subdivision of the unsupported taxon Protostomia. Those who are more strongly connected to the paradigm of the monophyly of the Protostomia would naturally tend to reject a hypothesis in which the Deuterostomia appear as a specialized clade of a protostomate group without a more detailed exposition of reasons and characters. For those who refuse to accept that the heterobathmy proposed for the Deuterostomia versus the Protostomia is well justified, however, a question naturally arises about which group would be the sister group of the Deuterostomia. Christoffersen \& Araújo-de-Almeida (1994) already discussed the insertion of the Deuterostomia within a larger clade. There seems to be good support for a taxon named Radialia, including bryozoans, phoronids, and deuterostomians. The question of the insertion of the Radialia within the protostomates would still require a solution.

Part of the difficulties concerning the placement of the Deuterostomia within the system of the higher metazoans seems actually due to an insufficient understanding of the body plan of the deuterostome ancestor. Because the phyla belonging the Deuterostomia are considerably old clades and because some intermediate taxa between them have certainly been extinct since their origin and are now missing in the system, the quite strong differences between them makes the optimization of general body features along the deuterostome clades difficult. What has been largely overlooked in the considerations about the deuterostome phylogeny is that in many smaller clades there is an opistosome or peduncle following the metasome.

In the Brachiopoda, only the inarticulates preserve this structure. Pterobranchs and cephalodiscids both retain a welldeveloped stalk, which is also present in the Crinoidea and other basal Echinodermata. Adult Enteropneusta Huxley, 1875 did not retain an opistosome, but it appears in some juvenile forms. In the urochordates, the larvaceans and larval ascidians have a structure - now called the notochord - that can be hypothesized to be homologous to the stalk of the basal Echinodermata. Cephalochordata and Vertebrata, despite changes in the body structure and biology, obviously present the notochord. Hence, independently from any discussion

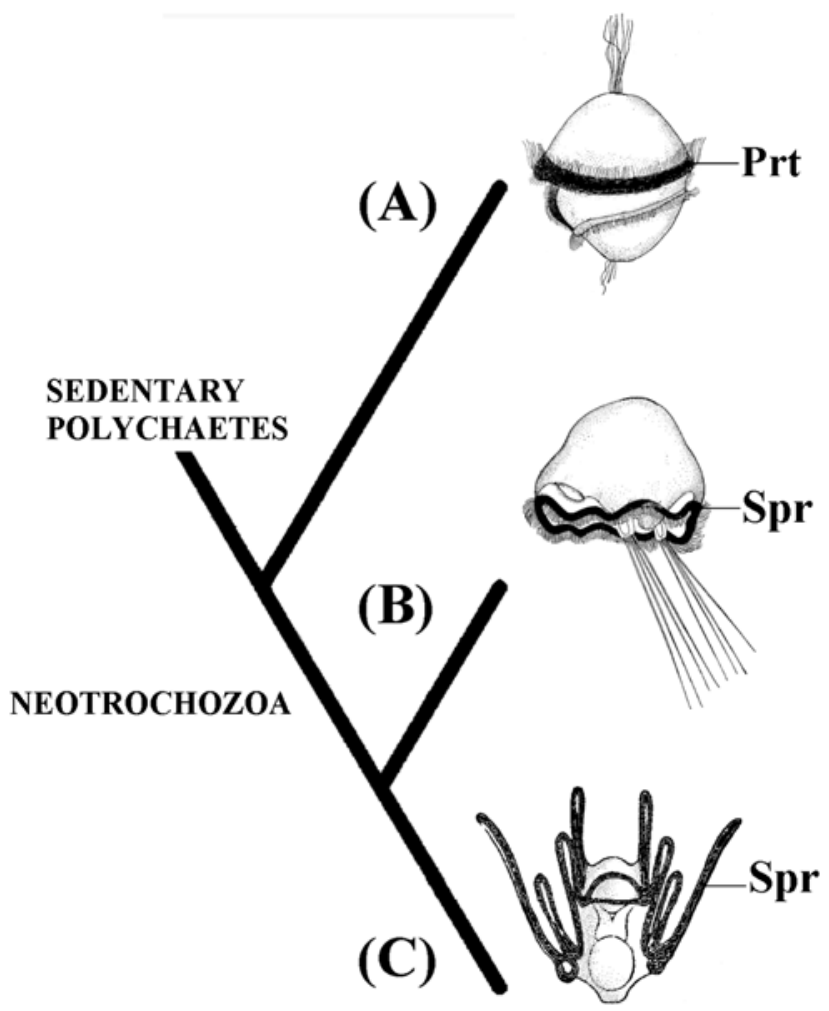

Figure 7. Hypotheses of some modifications occurring in larval characters of Neotrochozoa (Owenia + Enterocoela). (A) Polychaete typical trochophore represented by early larva of Polygordius sp. (Polygordiidae) (modified from Fauvel 1959); (B) Mitraria larva represented by early larva of Owenia fusiformis (Oweniidae) (modified from Fauvel 1959); (C) Tornaria represented by pluteus stage of ophiuromorphs (modified from WiLLIAMSON 1987). Prt, typic prototroch; Spr, sinuous deuterostome-like prototroch.

regarding the position of the deuterostomes in the system of the Metazoa, such a metasomal stalk is to be placed in the groundplan of the group.

Close to the deuterostomes, there may be a stalk in entoprocts (absent in ectoprocts), while phoronid larvae also present a post-prosome stalk, which degenerates during ontogeny. Lophophores or lophophore-like structures have a large distribution at the base of the Radialia. In the bryozoans, phoronids, brachiopods, and pterobranchs, the coelomate tentacles seem to be derived from a pair of pentameric structures that may often have numerous secondary divisions of the branches. In the Echinodermata, they are reduced to a pentameric structure and in the higher chordates they may be reduced to some short peri-oral projections or are completely absent. The formation of the peduncle appears to be connected to the displacement of the anus to a subterminal position the typical "U-shape" of the gut in most deuterostomes, from brachiopods to vertebrates. It is interesting to note how naturally a trimeric enterocoelic taxon such as the Pogonophora, formerly accepted as an independent phylum, 
was moved to within the annelids (Rouse \& Fauchald 1995, 1997). This appears to have been a wise perception, except that the remaining enterocoelous taxa should have been moved in together. Actually, in the evolution of the tubiculous polychaetes themselves, there is already a gradual development of two conspicuous anterior tagmas and a reduction of the posterior part of the body. The Pogonophora share a number of modifications present in the basal members of the radialian clade, but still retain much of the original polychaete condition.

\section{Validating the concept of the Ecdysozoa}

The groundplan of the Ecdysozoa is another issue insufficiently discussed in the literature from a strictly phylogenetic perspective. Maybe this is partially due to the doubts concerning the phylogenetic position of the Tardigrada within the Metazoa (sometimes displaced to the base of the bilaterians, within the old Pseudocoelomata Hyman, 1951). Or maybe because ecdysteroids are found in many other organisms, including plants and fungi (LAFONT 1997). This fact is decisive for Sörensen et al. (2000) and WäGELE \& Misof (2001) to question the validity of the Ecdysozoa. However, with the recent evidence of a phylogenetic connection of at least some of the Aschelminthes Grobben, 1910 with the panarthropods (e.g., Valentine \& Collins 2000; HaAse et al. 2001), additional clues appear. Even if just the Onychophora, Tardigrada, and Arthropoda were considered (leaving aside the Pentastomida and the Aschelminthes), by optimization some characters would necessarily appear at the base of the Ecdysozoa (see Almeida \& Christoffersen 2000: 17-21). One of the most interesting features is the development of a pharynx, armed with two pairs of unique mandibles placed biradially. A predatory habit can also be assigned to that level. Even though some of these features may be absent from the base of Arthropoda, their presence in Onychophora and Tardigrada are quite obvious. The ecdysozoan ancestor also had a locomotory system typical of a crawler, with sinuous body movements, enhanced by the action of longitudinal muscles. In a global (that is, parsimonious) analysis, these and other similarities make it reasonable that the Ecdysozoa fit, most closely, within a group of errant polychaetes (Fig. 6).

\section{On existing paradigms and the development of new hypotheses of homology and new topologies}

A particularly important aspect emerging from this discussion seems to be that at higher levels of metazoan phylogeny the a priori rejections of particular hypotheses of primary homology strongly influences the ability to get to alternative topologies. This is particularly evident in the case of the "pseudocoel", which for a long time was refused to be a derivation from a coelomic cavity (e.g., Willmer 1990; Erwin et al. 1997). Historically, the consequences have been that the Aschelminthes were displaced to a very basal position within the Bilateria, despite many evident features being shared with higher metazoan clades. These features include the evidences of metamery (ganglioned ventral nerve cord in Rotifera and Kinoryncha), the presence of a cuticle and of ecdysis, and the cuticular specializations of the anterior and posterior gut regions. It was necessary to wait for an independent source of information, like molecular data, to give credit again to the previous hypothesis of a closer relationship between the Aschelminthes and the Arthropoda.
Neglecting that parapodia can have primary homology with lobopodia seems to be another old paradigm resisting displacement. Almeida \& CHRISTOFFersen (2000) have extensively discussed its origin in MANTON's $(1967,1969,1973)$ characteristic views about homology and evolution of the arthropods. The aprioristic denial of such primary hypotheses of homology apparently has reduced the ability of systematists to recognize additional characters and possible alternative topologies. In other words, "forbidden" topologies block the development of new hypotheses of primary homology. In a similar way, "forbidden" homologies block the access to new topologies. The decisions regarding "good" and "bad" hypotheses of secondary homology must come from overall parsimony analyses, not from a priori argumentation considering the "amount of differences involved".

\section{Systematics: review of our main points, and establishment of a new system of the metameric metazoans}

Along this paper, we have sometimes inverted the polarities of characters in relation to earlier decisions of Rouse \& FAUCHALD (1997) have sometimes inverted the polarities of some characters in relation to earlier decisions. This is more a consequence of differences in methods of character coding, rather than to any a priori compromise with particular evolutionary outlooks, either progressive, with a gradual increase in character complexity (DALES 1962, 1963; HATSCHEK 1878, 1893), or regressive, with secondary simplifications (SтоRCh 1968; Pilato 1981). The effort of contemporary pattern cladists to reject aprioristic character interpretations isunderstandable, especially in view of the many mistakes and authoritative impositions of the past. However, abuses in the other direction, in the form of indiscriminate binary coding, sometimes with total disregard for the appropriate evolutionary context, can also obscure the phylogenetic signal provided by a few resolved characters.

For example, the Clitellata share several important synapomorphies particularly with Questidae. However, a large number of secondary absences of polychaetoid characters in the Clitellata, most of which are still present in the Sedentaria, tend to typologically exclude the clitellates from the Polychaeta. There is nevertheless ample phylogenetic evidence for the gradual reduction of these characters in the more closely related lineages of polychaetes (HessLING \& Westheide 1997; Purschke 1997, 1999; Purschre et al. 2000). Coding these absences simply as zeros and disregarding the available evidence for gradual reductions of characters tends to exclude the clitellates from the polychaetes and to reposition them near the base of the Metameria. Such coding is done in numerical cladistics by considering only presences/absences of characters, instead of indicating more extended transformation series where appropriate. The exclusion of the clitellates from the polychaetes leads to the necessity of reinterpreting a large number of similarities between the groups of scolecids, Questidae, and Clitellata as homoplasies (see results of Rouse $\&$ FAUCHALD 1995, 1997). The same would happen with all the specialized groups that present secondary simplicity due to adaptations to interstitial, pelagic, parasitic and commensal ways of life. Rouse \& Fauchald $(1995,1997)$ concluded that the Clitellata are basal annelids, as a consequence of their numerical cladistic coding procedures. However, they decided to treat a number of other "simple" polychaete families differently, by 
Almeida et al.

strategically excluding them from their final analyses. Under that kind of character treatment, this would be the only way to avoid that those groups accumulate as additional "basal" annelids lineages.

Working with broad clades such as the Metameria represents a real challenge to present practices of numerical cladistics (similar to phenetics; see WäGELE 1994, 1995, 1996a, 1999). To avoid the noise produce by that kind of coding it is necessary to deal with the entire range of the evolution of multistate characters and character reversions. The results of this paper show that the most parsimonious solution for the available information is that not only Polychaeta, but also Annelida and Articulata are paraphyletic groups. This is so not only because they exclude the Echiura or the highly derived Clitellata, but also because they exclude two other very large and important clades: the Ecdysozoa and the Enterocoela.

The present results also indicate the artificiality of the traditional division of the polychaetes into Errantia and Sedentaria. This conclusion agrees with at least some classical (Hartman 1959; Fauchald 1974, 1977; George \& HartmannSChröder 1985) and cladistic (Rouse \& Fauchald 1997) approaches. Instead of a dichotomy, the present analyses indicate a gradual, pectinate, and asymmetrical development of lineages, beginning with an errant, benthic, crawling, and predatory metamerian groundplan.

Several different approaches agree in part with our reconstruction: (1) Congruence in morphological and anatomical data may be found in Geoffroy Saint-Hillaire (1822), Dohrn (1875), STORCH (1968), FAuchald (1974 - his hypothesis of a creeping, burrowing, scolecid ancestor, may also be applied for the glycerids), Lauterbach (1978), Pilato (1981), Brusca \& Brusca (1990), Westheide (1997), Purschke (1997, 1999), and Hessling \& Westheide (1999), PurschKe et al. (2000); (2) partially overlapping conclusions from larvae, genetics, and embryology may be obtained in McGinnis et al. (1984), SмIтн (1988), LaWrence (1990), Emlet \& Strathmann (1994), Arendt \& NüblerJung $(1994,1997,1999)$, Nübler-Jung \& ARENdt $(1994,1999)$, Holland et al (1997), François \& Bier (1995) Holley et al (1995), Jones \& Smith (1995), Peterson \& Davidson (2000); and Peterson et al. (2000a, b).

Previous communications on these phylogenetic ideas may be obtained in Christoffersen \& ARAújo-DE-Almeida (1994) and Almeida \& Christoffersen (2000). The "basic plan" of the Metameria presented by Almeida \& Christoffersen (2000) is heuristic because it is based on synapomorphies that exist in actual specimens. Characters were not created to sustain preconceived evolutionary scenarios. Eliminating workable preconceptions from science is not advocated here, but the production of theory that is contrary to known data is objectionable.

The groups Palpata and Aciculata proposed by Rouse \& FAUCHALD (1997) also turn out to be paraphyletic in our analysis. Despite the new insights represented by the inclusion of such important groups as the Clitellata, Ecdysozoa, and Enterocoela, the proposed systematization of the Metameria is still close to traditional knowledge.

The results presented herein are simply hypotheses of relationships. They are tested either through corroboration or refutation of proposed characters or with the addition of new data on morphology, fossils, embryology, genes, etc. Data suggesting alternative relationships, however, must be overwhelming in their totality. In consonance with ALESHIN \& Petrov (1999: 194), it is remarked that a simple test of Bremer or a bootstrap value obtained from different data sets will not resolve which hypothesis is closer to the truth, as suggested by BRown et al. (1999). The strategy of character analysis should not mold the nature of the data, but phylogenetic hypothesis should be evaluated by the total extrinsic evidence available, and not exclusively by the selected body of intrinsic data (the matrix).

\section{Optimizing some biological features over the phylogeny: a general scenario of metamerian evolution}

The present analyses indicate that the origin of the Metameria may be associated with a change from a sedentary habit and non-metameric body plan, found in the outgroup, to a crawling animal with a metameric body plan (Fig. 3). Although several characters appear associated with this node (presence of parapodia, chaetae, jaws, lateral pairs of prostomial antennae, dorsal, ventral and anal cirri, and a hypertrophied axial proboscis), in the future more detailed analyses may demonstrate the gradual and sequential appearance of these structures.

The results of this work emphasize three main evolutionary trends within the Metameria. A first important evolutionary transition involves the origin of the largely continental Clitellata. Because in this lineage animals gradually adopt a sedentary mode of life, reversions of several character states back to conditions similar to those of the metamerian outgroups, which were, likewise, sedentary animals, were observed. Here again, the simplistic coding of several typical polychaete characters as absent in the clitellates tends to push the clitellates towards the base of the annelids. This practice ignores the evidence found throughout the scolecids indicating the gradual reduction of the more typical polychaete characters and the gradual acquisition of the clitellate evolutionary novelties (Fig. 5). The Questidae are here interpreted as a plausible connecting link between the more ancestral marine and estuarine scolecids and the highly derived and predominantly continental Clitellata (Fig. 5).

The second is related to the origin of the Ecdysozoa. Along this evolutionary line the neuropodia become gradually adapted for more efficient locomotion, subsequently function as lobopodia in the fossil lobopodians and recent onychophorans, and finally become articulated in arthropods (Fig. 6). The dorsal cirri may have become modified into elytrae and then into dorsal plates in the fossil lobopodians (see ALMEIDA $\&$ Christoffersen 2000: 42, fig. 11). The notopodia of the Aphrodita are very reduced (see Hutchings \& MCRAe 1993: Fig. 1a) because the chief organs of locomotion are represented by the neuropodia (FoRDHAM 1925: 11). Because the groundplan of the Ecdysozoa becomes highly modified with the gradual development of a chitinous exoskeleton, most polychaetoid characters are difficult to recognize in arthropods and their relatives.

A third evolutionary trend involves the origin of the Enterocoela, which revives and makes explicit the old theory of the worm or polychaete ancestry of the chordates (GEOFFroY SainT-Hillaire 1822; Dohrn 1875). This evolutionary line starts with a tagmatization of the anterior body region in the terebelliform polychaetes, which becomes well established in 
Pogonophora. Evidences of this tagmatization pattern are clearly present in Owenia. The condensed metameric posterior region of the body is strongly modified in the radialians, resulting in a conspicuous anterior oligomeric pattern typical of lophophorates and Deuterostomia. Changes in this evolutionary line also affect the larvae. The mitraria larvae of the Owenia can be interpreted as transitional between the typical trochophore larvae of other polychaetes and the tornaria larvae of the deuterostomates (Fig. 7). This shift in morphology seems to be closely related to a gradual change from the errant, plesiotypic habit to an excavatory, and then tubiculous, fully sedentary biology. In this evolutionary sequence there is an increasing importance of the anterior part of the body (and a proportional decrease of importance of the posterior part), which deeply affects the original homonomous metameric development.

\section{ACKNOWLEDGMENTS}

Our research was partially financed by the following funding agencies: Conselho Nacional de Desenvolvimento Científico e Tecnológico (CNPq), Fundação Coordenação de Aperfeiçoamento de Pessoal de Nível Superior (CAPES), and Fundação de Amparo à Pesquisa do Estado de São Paulo (FAPESP). We thank Prof. Dr. Greg Rouse (School of Biological Sciences, University of Sydney, Australia) for his criticisms of our work and suggestions on procedures offered during the VIth International Polychaete Conference, in Curitiba, Brazil. We thank Prof. Dr. Thomas Bartolomaeus (Fakultät für Biologie, Universität Bielefeld) for data on the chaetogenesis of the chaetopterid uncini. We also thank Prof. Dr. Johann W. Wägele (Fakultät für Biologie, Ruhr-Universität Bochum), Dra. Cinthya Santos (Universidade Federal do Paraná, Brasil) and Dr. Sergio Antônio Vanin (Universidade de São Paulo Brasil) for many criticisms and valuable suggestions on methods, coding of characters, and hypotheses of primary homology.

\section{REFERENCES}

Aguinaldo, A.M.A.; J.M. Tuberville; L.S. Linford; M.C. Rivera; J.R. GAREY; R.A. Rudolf \& J.A. LAKE. 1997. Evidence for a clade of nematodes, arthropods and other moulting animals. Nature 387: 4489-4493.

Aiyar, R.G. \& K.H. Alikunhi. 1940. On a new pisionid from the sandy beach, Madras. Records of the Indian Museum 42: 89-107.

ÅKesson, B. 1961. On the histological differentiation of the larvae of Pisione remota (Pisionidae, Polychaeta). Acta Zoologica, Stockholm, 42: 177-225.

Aleshin, V.V.; I.A. Milyutina; O.S. Kedrova; N.S. VladychensKaya $\&$ N.B. Petrov. 1998. Phylogeny of Nematoda and Cephalorhyncha derived from $18 \mathrm{~S}$ rDNA. Journal of Molecular Evolution 47: 597-605.

Aleshin, V.V. \& N.B. Petrov. 1999. Implicaciones del gen $18 \mathrm{~S}$ ARNr en la evolución y filogenia de los Arthropoda. Boletin de la Sociedad Entomologica Aragonesa, Zaragoza, 26: 177-196.

Almeida, W.O. \& M.L. Christoffersen. 1999. A cladistic approach to relationships in Pentastomida. Journal of Parasitology, Kansas 85 (4): 695-704.

- 2000. Análise cladística dos grupos basais de
Metameria: Uma nova proposta para o posicionamento dos Arthropoda e grupos afins entre os poliquetos errantes. Series Teses, Dissertações \& Monografias, I. Ribeirão Preto, Holos, 76p.

ALós, C. 1982. Algumas consideraciones filogenéticas sobre los arquianelidos. Publicaciones del Departamento de Zoologia, Universidad de Barcelona 8: 17-23.

AMORIM, D.S. 2002. Fundamentos de sistemática filogenética. Holos, Ribeirão Preto, XVIII + 154p.

ANDERSON, D.T. 1974. Embryology and phylogeny in annelids and arthropods. Pergamon Press, Oxford, XIV $+495 p$.

.1982. Origins and relationships among the animal phyla. Proceedings of the Linnean Society of New South Wales 106 (2): 151-166.

ARENDT, D. \& K. Nübler-Jung. 1994. Inversion of dorsoventral axis? Nature 371: 26.

. 1997. Dorsal or ventral: similarities in fate maps and gastrulation patterns in annelids, arthropods and chordates. Mechanisms of Development 61: 7-21.

1999. Comparison of early nerve cord development in insects and vertebrates. Development 126: 2309-2325.

Audouin, J.V. \& H. Milne Edwards. 1832. Classification des annélides et description de celles qui habitent les côtes de la France. Annales des Sciences Naturelles, série 1, 27: 337347.

Balavoine, G. 1996. Identification of members of several homeobox genes in a planarian using a ligation-mediated polymerase chain technique. Nucleic Acid Research 24 (8): 1547-1553.

. 1997. The early emergence of plathelminths is contradicted by the agreement between $18 \mathrm{~S}$ rRNA and Hox genes data. Comptes Rendus de l' Academie des Sciences de Paris, Sciences de la Vie 320: 83-94.

Balavorne, G. 1998. Are Platyhelminthes coelomates without a coelom? An argument based on the evolution of Hox genes? American Zoologist 38: 843-858.

Balavorne, G. \& M.J. Telford. 1995. Identification of planarian homeobox sequences indicates the antiquity of most Hox/ homeotic gene subclasses. Proceedings of the national Academy of Sciences of the United Sates of America 92: 7227-7231.

Ballard, J.W.O., G.J. Olsen; D.P. Faith; W.A. Odgers; D.M. Rowell \& P.W. AtKinson. 1992. Evidence from 12S ribossomal RNA sequences that onychophorans are modified arthropods. Science 258 (5086): 1345-1348.

Bartolomaeus, T. 1989. Ulrastructure and development of the nephridia in Anaitides mucosa (Annelida, Polychaeta). Zoomorphology 109: 15-32.

. 1995. Structure and formation of the uncini in Pectinaria auricoma (Terebellida) and Spirorbis spirorbis (Sabellida): Implications for annelid phylogeny and the position of the Pogonophora. Zoomorphology 115: 161177.

. 1997. Structure and development of the nephridia of Tomopteris helgolandica (Annelida). Zoomorphology 117: $1-11$.

1999. Sructure, function and development of segmental organs in Annelida. Hydrobiologia 42: 21-37.

Bartolomaeus, T. \& P. Ax. 1992. Protonephridia and metane- 
phridia - Their relation within the Bilateria. Zeitschrift für Zoologische und Systematisch Evolutionsforschung 30: 21-45.

Bartolomaeus, T. \& K. Meyer. 1997. Morphogenesis and phylogenetic significance of hooked setae in Arenicolidae (Polychaeta, Annelida). Invertebrate Biology 116 (3): 227242.

. 1999. Zur Phylogenie der Arenicolidae. Courier der Forschungs Institut Senckenberg 215: 23-29.

Bhaud, M. \& J.-C. Duchêne. 1996. Change from planktonic to benthic development: is life cycle evolution an adaptative answer to the constraints of dispersal? Oceanologia Acta 19 (3/4): 335-346.

Blainville, H. 1816. Prodrome d'une nouvelle distribution systématique du règne animal. Bulletin de la Societè philomathique de Paris, série 3, 1816: 105-124.

BLAKE, J.A. 1975. The larval development of Polychaeta from the northern California Coast. 3. Eigtheen species of Errantia. Ophelia 14 (1/2): 23-84.

Böggemann, M. 1997. Polychaeten aus der Deutschen Bucht. Taxonomische Bearbeitung und Dokumentation der von Forschungsinstitut Senckenberg hauptsächlich in der Deutschen Butcht gesammelten Polychaeten. Courier der ForschungsInstitut Senckenberg 202: 1-315.

Bonick, K.; M. Grasshoff \& W.F. Gutmann. 1976. Die Evolution der Tierkonstruktionen. 3. Von Gallertoid zur Coelomhydraulik. Natur und Museum 106 (6): 176-188.

BrinKhURST, R.O. 1971. Phylogeny and classification, part 1, p. 165-177. In: R.O. BRINKHURST \& B.G.M. JaMiESON (Eds). Aquatic Oligochaeta of the world. Edinburgh, Oliver \& Boyd, 860p.

. 1982. Evolution in the Annelida. Canadian Journal of Zoology 60 (5): 1043-1059.

-1984a. The position of the Haplotaxidae in the evolution of the oligochaete annelids. Hydrobiologia 115: 25-36.

. 1984b. Comments on the evolution of the Annelida. Hydrobiologia 109: 189-191.

. 1988. A taxonomic analysis of the Haplotaxidae (Annelida, Oligochaeta). Canadian Journal of Zoology 66 (10): 2243-2252.

. 1989. A phylogenetic analysis of the Lumbriculidae (Annelida, Oligochaeta). Canadian Journal of Zoology 67 (11): 2731-2739.

- 1991a. A phylogenetic analysis of the Tubificinae (Oligochaeta, Tubificidae). Canadian Journal of Zoology 69 (2): 392-397.

. 1991b. A phylogenetic analysis of the Phreodrilidae (Annelida, Oligochaeta) with a description of a new species. Canadian Journal of Zoology 69 (8): 20131-2040.

- 1992a. Ancestors. Mitteilungen der Hamburgischen Zoologisch Institut 88: 97-110.

. 1992b. Evolutionary relationships within the Clitellata. Soil Biology and Biochemistry 24 (12): 12011205.

. 1994. Evolutionary relationships within the Clitellata: An update. Megadrilogica 5 (10): 109-112.

BrINKHURST, R.O. \& B.G.M. JAMIESON. 1971. Aquatic Oligochaeta of the world. Edinburgh, Oliver \& Boyd, 860p.
BrINKHURST, R.O. \& A.F.L. NEMEC. 1987. A comparison of phenetic and phylogenetic methods applied to the systematics of Oligochaeta. Hydrobiologia 155: 65-74.

Brown, S., G.W. Rouse; P. Hutchings \& D. Colgan. 1999. Assessing the usefulness of histone H3, U2 snRNA and 28S rDNA in analyses of polychaete relationships. Australian Journal of Zoology 47: 499-516.

Brusca, R.C. \& G.J. Brusca. 1990. Invertebrates. Sinauer, Sunderland, Massachusetts, 992p.

BuDD, G.E. 1993. A Cambrian gilled lobopod from Greenland. Nature 364 (6439): 709-711.

- 1996. The morphology of Opabinia regalis and the reconstruction of the arthropod stem-group. Lethaia 29 (1): $1-14$.

BUNKE, D. 1994. Ultrastructure of the nephridial system in Aelosoma bengalense (Annelida). Zoomorphology 114: 247258.

Chambers, S.J. \& A.I. Muir. 1997. Polychaetes: British Chrysopetaloidea, Pisionoidea and Aphroditoidea, p. 1-202. In: R.S.K. Barnes \& J.H. CRothes (Eds). Synopses of the British Fauna, New Series, 54. London, The Linnean Society of London and The Estuarine and Coastal Sciences Association Studies Council.

Christoffersen, M.L. \& E. Araújo-de-Almeida. 1994. A phylogenetic framework of the Enterocoela (Metameria: Coelomata). Revista Nordestina de Biologia, João Pessoa, 9 (2): 173-208.

Clark, R.B. 1962. On the structure and functions of polychaete septa. Proceedings of the Zoological Society of London 138: 543-578.

. 1963. The evolution of the coelom and metameric segmentation, p. 91-107. In: E.C. DougherTy; Z.N. Brown; E.D. Hanson \& W.D. HaRTMan (Eds). The lower Metazoa: comparative biology and phylogeny. Berkeley, University of California Press, $478 \mathrm{p}$.

. 1964. Dynamics in metazoan evolution. London, Oxford University Press, 293p.

Collazo, A. 2000. Developmental variation, homology, and the pharyngula stage. Systematic Biology 49 (1): 3-18.

Collazo, A. \& S.E. Fraser. 1996. Integrating cellular and molecular approaches into studies of development and evolution: The issue of morphological homology. Aliso 14 (4): 237-267.

Соок, D.G. 1971. Anatomy of microdriles, p. 8-41. In: R.O. BRINKHURST \& B.G.M. JAMIESON (Eds). Aquatic Oligochaeta of the world. Edinburgh, Oliver \& Boyd, 860p.

CutLer, E.B. 1994. The Sipuncula. Their systematics, biology, and evolution. Ithaca, Comstock Publishing Associates, $416 \mathrm{p}$.

Cuvier, G. 1812. Sur un nouveau rapprochment à établir entre les classes qui composant le Règne Animal. Annales del Museum d'Histoire naturelle de Paris 19: 73-84.

. 1816. Le régne animal distribué aprés son organisation. Volume 9: Les Annélides. Paris, Déterville, p. 1-54.

DALES, R.P. 1952. The development and structure of the anterior region of the body in the Sabellariidae, with special reference to Phragmatopoma californica. Quarterly Journal 
of microscopical Science 93 (4): 435-452.

. 1962. The polychaete stomodeum and phylogeny, p. 525-545. In: D.J. Reish \& K. Fauchald (Eds). Essays on polychaetous annelids in memory of Dr. Olga Hartman. Los Angeles, Allan Hancock Foundation, 604p.

. 1963. Annelids. Hutchinson University Library, London, 200p

DAY, J.H. 1967. A monograph on the Polychaeta of Southern Africa. London, The British Museum (Natural History) Publication 656, VIII+458p.

Delle Cave, L.; E. Insom \& A.M. Simonetta. 1998. Advances, diversions, possible relapses and additional problems in understanding the early evolution of Articulata. Italian Journal of Zoology 65: 19-38.

Desbruyères, D. \& S. Hourdez. 2000a. A new species of scaleworm (Polychaeta: Polynoidae), Lepidonotopodium jouinae sp. nov. from the Azores Triple Junction on the Mid-Atlantic Ridge. Cahiers de Biologie marine 41: 399-405.

. 2000b. A new species of scale-worm (Polychaeta: Polynoidae), Lepidonotopodium atalantae sp. nov., from the East Pacific Rise at $13^{\circ} \mathrm{N}$ and $950^{\prime} \mathrm{N}$. Cahiers de Biologie marine 41 (1): 47-54.

Dohrn, A. 1875. Der Ursprung der Wirbeltiere und das Princip des Functionswechsels. Leipzig, Verlag von Wilhelm Engelmann.

Dzik, J. \& G. Krumbiegel. 1989. The oldest 'onychophoran' Xenusion: A link connecting phyla? Lethaia 22: 169-181.

Eernisse, D.J. 1997. Arthropod and annelid relationships reexamined, p. 43-56. In: R.A. Fortey \& R.H. Thomas (Eds). Arthropod relationships. London, The Systematics Association Special, vol. 55, Chapman \& Hall, 383p.

Eernisse, D.J.; J.S. Albert \& F.E. Anderson. 1992. Annelida and Arthropoda are not sister taxa. A phylogenetic analysis of spiralian metazoan morphology. Systematic Biology 41 (3): 305-330.

Eibye-JaCobsen, D. 1994. On the nature of the two anterior setigerous rings in Dorvilleidae and Dinophilidae (Annelida, Polychaeta). Mémoires du Museum national d'Histoire naturelle, Paris, 162: 93-100.

Eibye-Jacobsen, D. \& C. Nielsen. 1996. The rearticulation of annelids. Zoologica Scripta 25 (3): 275-282.

Emlet, R.B. \& R.R. Strathmann. 1994. Functional consequences of simple cilia in the mitraria of oweniids (an anomalous larva of an anomalous polychaete) and comparisons with other larvae, p. 143-157. In: W.H. WiLSON; S.A. STRICKer \& G.L. SHINN (Eds). Reproduction and development of marine invertebrates. Baltimore, Johns Hopkins University Press, 352p.

ERséus, C. 1984. Taxonomy and phylogeny of the gutless Phallodrilinae (Oligochaeta, Tubificidae), with descriptions of one new genus and twenty-two new species. Zoologica Scripta 13 (4): 239-272.

Erwin, D.; J.W. Valentine \& D. Jablonski. 1997. The origin of the animal body. American Scientist 85: 126-137.

FARRIS, J.S. 1989. Hennig86: a PC-DOS program for phylogenetic analysis. Cladistics 5 (2): 163-166.

Fauchald, K. 1974. Polychaete phylogeny: a problem in protostome evolution. Systematic Zoology 23: 493-506.

. 1977. The polychaete worms. Definitions and keys to the orders, families and genera. Natural History Museum, Los Angeles County Science Series 28: 1-188. . 1992a. A review of the genus Eunice (Polychaeta: Eunicidae). Smithsonian Contribution to Zoology 523: 1-422.

. 1992b. Review of the types of Palola (Eunicidae: Polychaeta). Journal of Natural History 26: 1177-1225.

Fauchald, K. \& G.W. Rouse. 1997. Polychaete systematics: Past and present. Zoologica Scripta 26: 71-138.

Fauvel, P. 1923. Polychaètes errantes. Faune de France 5 (1): 1243.

1959. Classe des annélides polychétes et oligochétes, p. 13-196. In: P.-P. Grassé (Ed.). Traité de zoologie: Anatomie, systématique et biologie. Paris, Masson et Cie, vol. 5, 1053p.

FerRaguti, M. \& C. ERséus. 1999. Sperm types and their use for a phylogenetic analysis of aquatic clitellates. Hydrobiologia 402: 225-237.

Field, K.G.; G.J. Olsen; D.J. Lane; S.J. Giovannoni; M.T. Ghiselin; E.C. RafF \& R. RAFF. 1988. Molecular phylogeny of the animal kingdom. Science 239: 748-753.

Fitzhugh, K. 1989. A systematic revision of the SabellidaeCaobangiidae-Sabellongidae complex (Annelida: Polychaeta). Bulletin of the American Museum of Natural History 192: 1-104.

Fordham, M.G.C. 1925. Aphrodita aculeata. Liverpool Marine Biology Committee Memoirs 27: 1-96.

FrançoIs, V. \& E. BiER. 1995. Xenopus chordin and Drosophila short gastrulation genes encode homologous proteins functioning in dorsal-ventral axis formation. Cell 80: 19-20.

Fryer, G. 1996. Reflections on arthropod evolution. Biological Journal of the Linnean Society 58: 1-55.

1998. A defense of arthropod polyphyly, p. 23-33. In: R.A. Fortey \& R.H. Thomas (Eds). Arthropod relationships. London, The Systematics Association Special, Chapman \& Hall, vol. 55, 383p.

GARDINER, S.L. 1978. Fine structure of the ciliated epidermis on the tentacles of Owenia fusiformis (Polychaeta, Oweniidae). Zoomorphology 91: 37-48.

Garey, J.R.; T.J. Near; M.R. NonNemacher \& S.A. Nadler. 1996. Molecular evidence for Acanthocephala as a subtaxon of Rotifera. Journal of Molecular Evolution 43: 287-292.

Garey, J.R.; A. Schmidt-Rhaesa; T.J. Near \& S.A. Nadler. 1998. The evolutionary relationships of rotifers and acanthocephalans. Hydrobiologia, 387/388: 83-91.

Geoffroy Saint-Hillaire, E. 1822. Philosophie anatomique. Paris, J.B. Bailliere, $517 p$.

George, J.D. \& G. Hartmann-Schröder. 1985. Polychaetes: British Amphinomida, Spintherida, and Eunicida. Keys and notes for the identification of the species, p. 1-221. In: D.M. Kermack \& R.S.K. Barnes (Eds). Synopses of the British Fauna (n. ser.). London, Brill, vol. 32, 221p.

Giangrande, A. 1997. Polychaete reproductive patterns, life cycles and life histories: an overview. Annual Review of Oceanography and marine Biology 35: 323-386.

Giangrande, A. \& M.C. Gambi. 1998. Metamerism and life-style within polychaetes: morpho-functional aspects and evolutionary implications. Italian Journal of Zoology 65: 
39-50.

Giani, N. \& E. Martinez-Ansemil. 1981. Observaciones acerca de algunos Tubificidae (Oligochaeta) de la Península Ibérica con la descripción de Phallodrilus riparius. Annales de Limnologie 17 (3): 201-209.

Giere, O.W. \& C. Erséus. 1998. A systematic account of the Questidae (Annelida, Polychaeta), with description of new taxa. Zoologica Scripta 27 (4): 345-360.

GIERE, O.W. \& N.W. RISER. 1981. Questidae - polychaetes with oligochaetoid morphology and development. Zoologica Scripta 10 (2): 95-103.

GiLPin-Brown, J.B. 1958. The development and structure of the cephalic nerves of Nereis. Journal of comparative Neurology 109: 317-348.

Giribet, G. \& C. Ribera. 1998. The position of arthropods in the animal kingdom: a search for a reliable outgroup for internal arthropod phylogeny. Molecular Phylogenetics and Evolution 9: 481-488.

. 2000. A review of arthropod phylogeny: new data based on ribosomal DNA sequences and direct charactes optimization. Cladistics, 16(2): 204-231.

GlasBy, C.J. 1993. Family revision and cladistic analysis of the Nereidoidea (Polychaeta: Phyllodocida). Invertebrate Taxonomy 7 (6): 1551-1573.

Goodrich, E.S. 1945. The study of nephridia and genital ducts since 1895. Quarterly Journal of Microscopy 86: 113-392.

Green, K.D. 1982. Uncispionidae, a new polychaete family (Annelida). Proceedings of the Biological Society of Washington 95: 530-536.

Grube, A.E. 1850. Die Familien der Annelidien. Arch. Naturg. Berlin 16(1): 249-364.

Gupta, B. \& C. LitTle. 1970. Studies on Pogonophora. 4. Fine structure of the cuticle and epidermis. Tissue \& Cell 2: 637696.

Gustafson, G. 1930. Anatomische studien über die polychätenfamilien Amphinomidae und Euphrosynidae. Zoologica Bidragen Uppsala 12: 305-471.

Gustavsson, L.M. \& C. ERséus. 2000. Cuticular ultrastructure in some marine oligochaetes (Tubificidae). Invertebrate Biology 119 (2): 152-166.

Gustus, R.M. \& R.A. Cloney. 1972. Ultrastructural similarities between setae of brachiopods and polychaetes. Acta Zoologica, Stockholm 53: 229-233.

Налström, B. 1928. Vergleichende Anatomie des Nervensystems der wirbellosen Tiere, unter Berückisichtigung seiner Funktion. Berlin, Springer, XI + 628p.

HaAse, A., M. Stern, K. Wächtler \& G. Bicker. 2001. A tissuespecific marker of Ecdysozoa. Development Genes and Evolution 211:428-433.

Hanström, B. 1930. Beitrag zur Diskussion des Kopjlappens der Polychaeten. Lunds Universitet Ärsskrifter, N.F., 42 (3): 1-29.

Harmer, M.L., M.J. Samways \& H. Ruhberg. 1997. A review of the Onychophora of South Africa, with a discussion of their conservation. Annals of the Natal Museum 38: 383-312.

Hartman, O. 1950. Polychaetous annelids. Goniadidae, Glyceridae, and Nephtyidae. Allan Hancock Pacific Expedition 15: 1-181.
1959. Catalogue of the polychaetous annelids of the world. Part I. Occasional Papers of the Allan Hancock Foundation 23: 1-628.

. 1965. Deep-water benthic polychaetous annelids of New England, Bermuda and other North Atlantic areas. Occasional Papers of the Allan Hancock Foundation 28: 1-378.

-1968. Atlas of the errantiate polychaetous annelids from California. Los Angeles, Allan Hancock Foundation, 828p.

1969. Atlas of the sedentariate polychaetous annelids from California. Los Angeles, Allan Hancock Foundation, IV $+812 p$.

Haszprunar, G. 1992. The first molluscs - small animals. Bolletino di Zoologia 59: 1-16.

Натsснек, B. 1878. Studien über die Entwicklungsgeschichte der Anneliden. Arbeiten der Zoologische Institut der Universität Wien 1 (3): 177- 404.

1893. System der Anneliden, ein vorläufiger Bericht. Lotos 13: 123-126.

Hausen, H. \& T. Bartolomaeus. 1998. Setal structure and chaetogenesis in Scolelepis squamata and Malacoceros fuliginosus (Spionidae, Annelida). Acta Zoologica, Stockholm, 79 (3): 149-161.

HenNIG, W. 1966. Phylogenetic systematics. Urbana, University of Illinois Press, 263p.

Hermans, C.O. 1969. The systematic position of Archiannelida. Systematic Zoology 18 (1): 85-102.

Hessling, R. \& W. Westheide. 1999. CLSM analysis of development and structure of the central nervous system of Enchytraeus crypticus ("Oligochaeta", Enchytraeidae). Zoomorphology 119: 37-47.

Holland, L.; M. Kene; N.A. Williams \& N. Holland. 1997. Sequence and embryonic expression of the amphioxus engrailed gene (AmphiEn): the metameric pattern of transcription resembles that of its segment-polarity homolog in Drosophila. Development 124: 1723-1732.

Holley, S.A.; P.D. JaCKSON; Y. SASAI; B. Lu; E.M. DE Robertis; F.M. Hoffmann \& E.L. Ferguson. 1995. A conserved system for dorsal-ventral patterning in insects and vertebrates involving sog and chordin. Nature 376: 249-253.

Holthe, T. 1986. Evolution, systematics, and distribution of the Polychaeta Terebellomorpha, with a catalogue of the taxa and a bibliography. Gunneria 55: 1-236.

Hutchings, P. \& J. McRae. 1993. The Aphroditidae (Polychaeta) from Australia, together with a redescription of the Aphroditidae collected during the Siboga expedition. Records of the Australian Museum 45: 279-363.

Hutchings, P. \& A. Murray. 1984. Taxonomy of polychaetes from the Hawkesbury River and southern estuaries of New South Wales, Australia. Records of the Australian Museum, Supplement 3: 1-118.

Hyman, L.H. 1951. The invertebrates: Platyhelminthes and Rhynchocoela. New York, McGraw-Hill Book Co., vol. 1, 726p. . 1959. The invertebrates: Smaller coelomate groups. New York, McGraw-Hill Book Co., vol. 5, 783p.

ImAJIMA, M. 1989. Spionidae (Annelida, Polychaeta) from Japan, I. The genera Aonides and Apoprionospio. Bulletin of the 
National Science Museum, Tokyo, 15 (5): 213-222.

- 1997. Polychaeous annelids of Suruga Bay, Central Japan. Memoires of the National Science Museum, Tokyo, 12: 149-228.

Imajima, M. \& T. Hove. 1984. Serpulinae (Annelida, Polychaeta) from the Turk Islands, Ponape, and Majuro Atoll, with some other new Indo-Pacific records. Proceedings of the Japan Society of Systematics and Zoology 27: 35-66.

Imajima, M. \& J. Morita. 1987. Oweniidae (Annelida, Polychaeta) from Japan. Bulletin of the National Science Museum, Tokyo, 13 (3): 85-102.

ImAJIMA, M. \& J. TAKEDA. 1985. Nephtyidae (Polychaeta) from Japan. Bulletin of the National Science Museum, Tokyo, 11 (2): 57-90.

Ivanov, A.V. 1957. On the systematic position of Pogonophora. Systematic Zoology 15: 165-173.

. 1963. Pogonophora. London, Academic Press, XVI $+479 \mathrm{p}$.

Jägersten, G. 1936. Zur Kenntnis der Morphologie Entwicklung und Taxonomie der Myzostomida. Nova Acta royal Society of Uppsala 11: 1-84.

JAMIESON, B.G.M. 1981. The ultrastructure of the Oligochaeta. London, Academic Press, 462p.

- 1983. Spermiogenesis in the oligochaetoid polychaete Questa (Annelida, Questidae). Zoologica Scripta 12 (3): 179-186.

Jamieson, B.G.M. \& R.I. Webв. 1984. The morphology, spermatozoal ultrastructure and phylogenetic affinities of a new species of questid (Polychaeta; Annelida), p. 21-34. In: P.A. Hutchings (Ed.). Proceedings of the First International Polychaete Conference, Sydney, Australia. Sydney, The Linnean Society of New South Wales.

Jones, C.M. \& J.C. SмiтH. 1995. Revolving vertebrates. Current Biology 5: 574-576.

Karuppaswamy, S.A. 1977. Occurrence of $\beta$-chitin in the cuticle of a pentastomid Raillietiella gowrii. Experientia 33: 735736.

Kielan-Jaworowska, Z. 1966. Polychaetes jaw apparatuses from the Ordovician and Silurian of Poland and a comparison with modern forms. Palaeontologia Polonica 16: 1-152.

Kim, C.B.; S.Y. Moon; S.R. Gelder \& W. Kim. 1996. Phylogenetic relationships of annelids, molluscs, and arthropods evidenced from molecules and morphology. Journal of Molecular Evolution 43: 207-215.

KoJIMA, S. 1998. Paraphyletic status of Polychaeta suggested by phylogenetic analysis based on the amino acid sequences of elongation factor X. Mololecular Phylogenetics and Evolution 9 (2): 255-261.

Kristensen, R.M. \& D. Eibye-Jacobsen. 1995. Ultrastructure of spermiogenesis and spermatozoa in Diurodrilus subterraneus (Polychaeta, Diurodrilidae). Zoomorphology 115: 117-132.

LAFONT, R. 1997. Ecdysteroids and related molecules in animals and plants. Archives del Institut de Biochemie und Physiologie 35: 3-20.

LAMARCK, J.-B. DE. 1801. Système des animaux sans vertèbres, ou tableau général des classes, des orders et des genres de ces animaux. Paris, Déterville, 432p.

LAUTERBACH, K.-E. 1978. Gedanken zur Evolution der Euarthro-
poden-Extremität. Zoologische Jahrbuch, Anatomie 99: 64-92.

LAWRENCE, P.A. 1990. Compartments in vertebrates? Nature 344: 382-383.

LinNAeus, C. 1758. Systema naturae. Holmiae, Laurentii Salvii, $10^{\text {th }}$ ed., vol. 1 .

Mackie, A.S.Y. \& S.J. Chambers. 1990. Revision of the type species of Sigalion thalenessa and Eusigalion (Polychaea: Sigalionidae). Zoologica Scripta 19 (1): 39-56.

MANTON, S.M. 1952. The evolution of arthropodan locomotory mechanisms. Part 2. General introduction to the locomotory mechanisms of the Arthropoda. Journal of the Linnean Society of London Zoology 42: 93-117.

. 1967. The polychaete Spinther and the origin of the Arthropoda. Journal of Natural History 1: 1-22.

- 1969. Evolution and affinities of Onychophora, Myriapoda, Hexapoda, and Crustacea, p. 15-57. In: R.C. Moore (Ed.). Treatise on Invertebrate Paleontology Part R Arthropoda. Lawrence, The Geological Society of America and University of Kansas, vol. 4, 650p.

. 1973. Arthropod phylogeny - A modern synthesis. Journal of Zoology, London, 171: 111-130.

. 1977. The Arthropoda: habits, functional morphology and evolution. London, Oxford University Press, $\mathrm{XX}+527 \mathrm{p}$.

McGinnis, W.; C.P. Hart; W.J. Gehring \& F.H. Ruddle. 1984. Molecular cloning and chromosome maping of a mouse DNA sequence homologous to homeotic genes of Drosophila. Cell 38: 675-680.

McHugh, D. 1997. Molecular evidence that echiurans and pogonophorans are derived annelids. Proceedings of the Natural Academy of Scienceof the United States of America 94 (15): 8006-8009.

. 1999. Phylogeny of the Annelida: Siddall et al. (1998) rebutted. Cladistics 15: 85-89.

.2000. Molecular phylogeny of the Annelida. Canadian Journal of Zoology 78: 1873-1884.

McHugh, D. \& G.W. Rouse. 1998. Life history of marine invertebrates: new views from phylogenetic systematics. Trends in Ecology and Evolution 13 (5): 182-186.

Metтaм, C. 1971. Functional design and evolution of the polychaete Aphrodita aculeata. Journal of Zoology, London, 163: 489-514.

Meyer, E. 1887. Studien über Köperbau der Anneliden. I-III. Mitteilungen der Zoologische Station Neapel 7: 592-741. . 1888. Studien über Köperbau der Anneliden. IV. Mitteilungen der Zoologische Station Neapel 8: 462-662. . 1901. Studien über Köperbau der Anneliden. V. Das Mesoderm der Ringelwürmer. Mitteilungen der Zoologische Station Neapel 14: 247-584.

Meyer, K. \& T. Bartolomaeus. 1996. Ultrastructure and formation of the hooked chaetae in Owenia fusiformis Delle Chiaje, 1842: Implications for annelid phylogeny. Canadian Journal of Zoology 74 (12): 2143-2153.

MikKelsen, P.M. 1998. Review of shell reduction and loss in traditional and phylogenetic molluscan systematics, with experimental manipulation of negative gain character. American malacological Bulletin 14 (2): 201-218. 
MiLeikovsky, S.A. 1968. A morphology of larvae and systematics of Polychaeta. Zoologichesky Zhurnal 47 (1): 59-59.

. 1977. On the systematic interrelationships within the Polychaeta and Annelida: an attempt to create an integrated system based on their larval morphology, p. 503524. In: D.J. Reish \& K. Fauchald (Eds). Essays on polychaetous annelids. In memory of Dr. Olga Hartman. Los Angeles, Allan Hancock Foundation, 604p.

Monge-Nájera, J. 1995. Phylogeny, biogeography and reproductive trends in Onychophora. Zoological Journal of the Linnean Society 114: 21-60.

Monge-Nájera, J. \& X.-G. Hou. 1999. 500 millones de años de evolución: Onicóforos, los primeros animales que caminaron (Onychophora). Boletin de la Sociedad Entomológica Aragonesa, Zaragoza 26: 171-176.

Moura, G. \& M.L. Christoffersen. 1996. The system of the mandibulate arthropods: Tracheata and Remipedia as sister groups; 'Crustacea' non-monophyletic. Journal of Comparative Biology, Ribeirão Preto 1 (3/4): 95-113.

NieLSEN, C. 1995. Animal evolution: Interrelationships of the living phyla. Oxford University Press, Oxford, $X+467 p$.

Nielsen, R. \& T. Holthe. 1985. Artic and scandinavian Oweniidae (Polychaeta) with a description of Myriochele fragilis sp. n., and comments on the phylogeny of the family. Sarsia, Oslo, 70 (1): 17-32.

Nixon, K. C. \& J.M. Carpenter. 1993. On outgroups. Cladistics 9 (4): 413-426.

Nübler-Jung, K. \& D. ARendt. 1994. Is ventral in insects dorsal in vertebrates? A history of embryological arguments favouring axis inversion in chordate ancestors. Roux's Archives of developmental Biology 203: 357-366.

. 1999. Dorsoventral axis inversion: Enteropneust anatomy links invertebrates to chordates turned upside down. Journal of zoological and Systematic evolutionary Research 37: 93-100.

Омодеo, P. 1998. History of Clitellata. Italian Journal of Zoology 65: 51-73.

Orensanz, J.M. 1990. The eunicemorph polychaete annelids from Antarctic and Subantarctic Seas. With addenda to the Eunicemorpha of Argentina, Chile, New Zealand, Australia, and the Southern Indian Ocean. Antarctic Research Series 52: 1-183.

Orrhage, L. 1964. Anatomische und morphologische Studien über die Polychaetenfamilien Spioniae, Disomidae und Poecilochaetidae. Zoologica Bijdragen, Uppsala 36 (3): 335-405, pls 1-12.

— 1966. Über die Anatomie des zentralen Nervensystemes der sedentären Polychaeten. Arkiv für Zoologi 19: 99-133.

- 1973a. Two fundamental requeriments for phylogenetic-scientific works as a background for an analysis of Dale's 1962 and Webb's 1969 theories. Zeitschrift für Zoologisch und Systematisch Evolutionsforschung 11: 161-173.

. 1973b. Light and electron microscopic studies of some brachiopod and pogonophoran setae. Zeitschrift für Morphologie und Ökologie der Tiere 74: 253-270.

. 1974. Über die Anatomie, Histologie und Verwandtschaft der Apistobranchidae (Polychaeta Sedentaria) nebst
Bemerkungen über die systematische Stellung der Archianneliden. Zeitschrift für Morphologie und Ökologie der Tiere 79: 1-45.

.1978. On the structure and evolution of the anterior end of Sabellariidae (Polychaeta Sedentaria), with some remarks on the general organisation of the polychaete brain. Zoologische Jahrbuch, Abteilung für Anatomie und Ontogenie der Tiere 100: 343-374.

. 1980. On the structure and homologues of the anterior end of the polychaete families Sabellidae and Serpulidae. Zoomorphology 96: 113-168.

.1990. On the microanatomy of the supraesophageal ganglion of some amphinomids (Polychaeta Errantia), with further discussion of the innervation and homologues of the polychaete palps. Acta Zoologica, Stockholm, 71: 4559.

1991. On the innervation and homologues of the cephalic appendages of the Aphroditacea (Polychaeta). Acta Zoologica, Stockholm, 72: 233-246.

1993. On the microanatomy of the cephalic nervous system of Nereidae (Polychaeta), with a preliminary discussion of some earlier theories on the segmentation of the polychaete brain. Acta Zoologica, Stockholm, 74: 145172 .

. 1995. On the innervation and homologues of the anterior end appendages of the Eunicea (Polychaeta), with a tentative outline of a fundamental constitution of the cephalic nervous system of the polychaetes. Acta Zoologica, Stockholm, 76: 229-248.

. 1996. On the microanatomy of the brain and the innervation and homologues of the cephalic appendages of Hesionidae and Syllidae (Polychaeta). Acta Zoologica, Stockholm, 77: 137-151.

Panganiban, G.; S.M. Irvine; C. Lowe; H. Rohel; L.S. Corley; B. Sherbon; J. K. Grenier; J.F. Fallon; J. Kimble; M. Walker; G.A. Wray; B.J. Swalla; M.Q. Martindale \& S.B. Carroll. 1997. The origin and evolution of animal appendages. Proceedings of the Natural Academy of Science of the United States of America 94: 5162-5166.

Peterson, K.J.; R.A. Cameron \& E.H. Davidson. 2000a. Bilaterian origins: significance of new experimental observations. Developmental Biology 219: 1-47.

Peterson, K.J. \& E.H. Davidson. 2000. Regulatory evolution and the origin of the bilaterians. Proceedings of the Natural Academy of Scienceof the United States of America 97 (9): 4430-4433.

Peterson, K.J.; S.Q. Irvine; R.A. Cameron \& E.H. Davidson. 2000 b. Quantitative assessment of Hox complex expression in the development of the polychaete annelid Chaetopterus sp. Proceedings of the Natural Academy of Science of the United States of America 97 (9): 4487-4492.

Pettibone, M.H. 1963. Marine polychate worms of the New England region. I, Aphroditidae through Trochochaetidae. Bulletin of the United States national Museum 227: 1356.

.1966. Heteroaphrodita altoni, a new genus and species of polychaete worms (Polychaeta, Aphroditidae) from deep water of Oregon and a revision of the aphroditid genera. Proceedings of the Biological Society of Washington 79: 95-107. 
1982. Annelida, p. 1-43. In: S.P. PARKER (Ed.). Synopsis and classification of living organisms. New York, McGrawHill, vol. 2, 1232p.

. 1983. A new scale worm (Polychaeta: Polynoidae) from the hydrothermal rift-area off western Mexico at $21^{\circ} \mathrm{N}$. Proceedings of the Biological Society of Washington 96: 392-399.

. 1984. Two new species of Lepidonotopodium (Polychaeta: Polynoidae: Lepidonotopodinae) from the hydrothermal vents off Galapagos and East Pacific Rise at $21^{\circ} \mathrm{N}$. Proceedings of the Biological Society of Washington 97: 849-863.

. 1989. Revision of the aphroditoid polychaetes of the family Acoetidae Kinberg ( = Polyodontidae Augener) and reestablishment of Acoetes Audouin and Milne-Edwards, 1832, and Euarche Ehlers, 1887. Smithsonian Contributions to Zoology 464: 1-138.

Philippe, H.; A. Chenuil \& A. Adoutte. 1994. Can the Cambrian explosion be inferred through molecular phylogeny? Development 120 (Suppl.): 15-25.

Pilato, G. 1981. The significance of musculature in the origin of the Annelida. Bolletino di Zoologia 48: 209-226.

Pilgrim, M. 1966. The morphology of the head, thorax, proboscis apparatus and pygidium of the maldanid polychaetes Clymenella torquata and Euclymene oerstedi. Journal of Zoology 148: 453-475.

Pleijel, F. \& T. Dahlgren. 1998. Position and delineation of Chrysopetalidae and Hesionidae (Annelida, Polychaeta, Phyllodocida). Cladistics 14 (2): 129-150.

PurschKe, G. 1984. Vergleichende anatomische und ultrastrukturelle Undersuchungen ventraler Pharynxapparate bei Polychaeten und ihre phylogenetische Bedeutung. Doktorgrades Dissertation. Göttingen, Georg-AugustUniversität zu Göttingen.

. 1985a. Anatomy and ultrastructure of ventral pharyngeal organs and their phylogenetic importance in Polychaeta (Annelida) 1. The pharynx of the Dinophilidae. Zoomorphology 105: 223-239.

- 1985b. Anatomy and ultrastructure of ventral pharyngeal organs and their phylogenetic importance in Polychaeta (Annelida) 2. The pharynx of the Nerillidae. Mikrofauna Marine 2: 23-60.

- 1987a. Anatomy and ultrastructure of ventral pharyngeal organs and their phylogenetic importance in Polychaeta (Annelida) 3. The pharynx of the Parergodrilidae. Zoological Journal of Anatatomy 115 (3): 331-362.

. 1987b. Anatomy and ultrastructure of ventral pharyngeal organs and their phylogenetic importance in Polychaeta (Annelida) 4. The pharynx and jaws of the Dorvilleidae. Acta Zoologica, Stockholm, 68 (2): 83-105.

. 1988a. Anatomy and ultrastructure of ventral pharyngeal organs and their phylogenetic importance in Polychaeta (Annelida) 5. The pharynges of the Ctenodrilidae and Orbiniidae. Zoomorphology 108: 119-135.

. 1988b. Pharynx, p. 177-197. In: W. Westheide \& C.O. Hermans (Eds). The ultrastructure of the Polychaeta. Microfauna Marina 4. Stuttgart, Fischer, 494p.

1993. Structure of the prostomial appendages and the central nervous system in the Protodrilida (Polychaeta).
Zoomorphology, 113: 1-20.

.1997. Ultrastructure of nuchal organs in polychaetes (Annelida) - New results and review. Acta Zoologica, Stockholm, 78 (2): 123-143.

. 1999. Terrestrial polychaetes - models for the evolution of Clitellata (Annelida)? Hydrobiologia 406: 87 99.

PurschKe, G. \& C. Jouin. 1988. Anatomy and ultrastructure of the ventral pharyngeal organs of Saccocirrus (Saccocirridae) and Protodriloides (Protodriloidae new family) with remarks on the phylogenetic relationships within the Protodrilida (Annelida: Polychaeta). Journal of Zoology 215 (3): 405432.

Purschke, G. \& A.B. TzeLin. 1996. Dorsoventral ciliary folds in the polychaete foregut: Structure, prevalence and phylogenetic significance. Acta Zoologica, Stockholm, 77: 33-49.

PurschKe, G.; H. Hessuing \& W. Westheide. 2000. The phylogenetic position of the Clitellata and the Echiura - on the problematic assessment of absent characters. Journal of zoological Systematics and evolutionary Research 38: 165-173.

Purschke, G.; W. Westheide; D. Rhode \& R.O. Brinkhurst. 1993. Morphological reinvestigation and phylogenetic relationship of Acanthobdella peledina (Annelida, Clitellata). Zoomorphology 113: 91-101.

Quatrefages, A. 1866. Histoire naturelle des annelés marines et d'eau douce. Paris, Librarie Encyclopédique de Roret, vol. 1 VII + 588p., vol. 2 794p.

Ramos, T.C. 1996. Tree Gardener version 2.2. P.C. program for Windows.

Remane, A. 1956. Die Grundlagen des natürlichen Systems, der vergleichenden Anatomie und der Phylogenetik. Leipzig, Geest \& Portig., 364p.

RICE, M.E. 1993. Sipuncula, p. 237-325. In: F.W. HARRISON \& M.E. RICE (Eds). Microscopic anatomy of invertebrates. New York, Wiley-Liss, vol. 12, 484p.

Rota, E. 1998. Morphology and adaptations of Parergodrilus Reisinger and Hrabeiella Pizl and Chalupský, two enigmatic soil-dwelling annelids. Italian Journal of Zoology 65: 7584.

Rota, E. \& P. LupetTi. 1997. An ultrastructural investigation of Hrabeiella Pizl \& Chalupský, 1984 (Annelida). II. The spermatozoon. Tissue \& Cell 29 (5): 603-609.

Rouse, G.W. 1997. Rearticulating Annelida with extra assumptions: A response to Eibye-Jacobsen and Nielsen. Zoologica Scripta 26 (1): 61-66.

. 1999. Trochophore concepts: ciliary bands and the evolution of larvae in spiralian Metazoa. Biological Journal of the Linnean Society 66: 411-464.

. 2000. The epitome of hand waving? Larval feeding and hypotheses of metazoan phylogeny. Evolution \& Development 2 (4): 222-233.

Rouse, G.W. \& K. FAUCHALD. 1995. The articulation of annelids. Zoologica Scripta 24 (4): 269-301.

. 1997. Cladistics and polychaetes. Zoologica Scripta 26 (2): 139-204.

. 1998. Recent views on the status, delineation and 
classification of the Annelida. American Zoologist 38 (6): 953-964.

Rouse, G.W. \& K. Fitzhugh. 1994. Broadcasting fables: is external fertilization really primitive? Sex, size, and larvae in sabellid polychaetes. Zoologica Scripta 23: 271-312.

Runnegar, B. 1982. Oxygen requeriments, biology and phylogenetic significance of the late Precambrian worm Dickinsonia, and evolution of burrowing habit. Alcheringa 6: 223-239.

SAlVINI-Plawen, L.V. 1982. A paedomorphic origin of oligomerous animals? Zoologica Scripta 11 (2): 77-81.

. 1988. Annelida and Mollusca: A prospectus, p. 383396. In: W. Westheide \& C.O. Hermans (Eds). The ultrastructure of the Polychaeta. Microfauna Marina 4. Stuttgart, Fischer, 494p.

. 2000. What is convergent/ homoplastic in Pogonophora? Journal of zoological Systematics and evolutionary Research 38 (3): 133-147.

Scheltema, A.H. 1993. Aplacophora as progenetic aculiferans and the coelomate origin of mollusks as sister taxon of Sipuncula. Biological Bulletin of the marine Biology Laboratory, Plymouth, 184: 67-78.

Scheltema, A.H.; M. Tscherkassky \& A.M. Kuzirian. 1994. Aplacophora, p. 13-54. In: R.W. HARRISON \& A.J. KoHN (Eds). Microscopic anatomy of invertebrates, volume 5. Mollusca: Monoplacophora, Aplacophora, Polyplacophora, and Gastropoda. New York, Wiley-Liss.

Schmidt-Rhaesa, A.; T. Bartolomaeus; C. Lemburg; U. Ehlers \& J.R. Garey. 1998. The position of the Arthropoda in the phylogenetic system. Journal of Morphology 238: 263-285.

Schram, F.R. 1986. Crustacea. New York, Oxford University Press, XVI+606p.

Schram, F.R. 1991. Cladistic analysis of metazoan phyla and the placement of fossil problematica, p. 35-46. In: A SIMONETA $\&$ S. CONWAY MorRIS (Eds). The early evolution of Metazoa and the significance of problematic taxa. Cambridige, Cambridge University Press, 296p.

Schram, F.R. \& M.J. Emerson. 1991. Arthropod pattern theory: A new approach to arthropod phylogeny. Memories of the Queensland Museum 31: 1-18.

Schröder, P.C. \& C.O. Hermans. 1975. Annelida: Polychaeta, p. 1-213. In: A.C. Giese \& J.S. PeARSE (Eds). Reproduction of marine invertebrates. New York, Academic Press, vol. 3.

Schweigkofler, M.; T. Bartolomaeus \& L.V. Salvini-Plawen. 1998. Ultrastructure and formation of hooded hooks in Capitella capitata (Fabricius, 1780) (Capitellida, Annelida). Zoomorphology 118: 117-128.

Sharov, A.G. 1966. Basic arthropodan stock, with special references to insects. Oxford, Pergamon Press.

Shubin, N.; C. Tabin \& S. Carroll. 1997. Fossils, genes and the evolution of animal limbs. Nature 388: 639-648.

Siddall, M.E.; K. Fitzhugh \& K.A. Coates. 1998. Problems determining the phylogenetic position of echiurans and pogonophorans with limited data. Cladistics 14 (4): 401-410.

SMITH, P.R. \& E.E. Ruppert. 1988. Nephridia, p. 231-262. In: W. Westheide \& C.O. HeRmans (Eds). The ultrastructure of the Polychaeta. Microfauna Marina 4. Stuttgart, Fischer, 494p.

SMith, P.R.; E.E. Ruppert \& S.L. Gardiner. 1987. A deuterostome- like nephridium in the mitraria larva of Owenia fusiformis (Polychaeta, Annelida). Biological Bulletin 172: 315-323.

SмITH, R.I. 1988. Mixonephridia or nephromixia in terebellid polychaetes? A classification. Comparative Biochemistry and Physiology 91: 265-272.

SOMMER, R.J. 1999. Convergence and the interplay of evolution and development. Evolution \& Development 1 (1): 8-10.

Sörensen, M.V.; P. Funch; E. Willerslev; A.J. Hansen \& J. Olsen. 2000. On the phylogeny of the Metazoa in the light of Cycliophora and Micrognathozoa. Zoologischer Anzeiger 239: 297-318.

SouthWARD, E.C. 1988. Development of the gut and segmentation of newly settled stages of Ridgeia (Vestimentifera): Implications for relationships between Vestimentifera and Pogonophora. Journal of the marine Biological Asociation of the United Kingdom 68: 465-487.

SouthWard, E.C. 1993. Pogonophora, p. 327-369. In: F.W. HARRISON \& M.E. RICE (Eds). Microscopic anatomy of invertebrates, volume 12 . Onychophora, Chilopoda and lesser Protostomia. New York, Wiley-Liss.

Specht, A. 1988. Chaetae, p. 45-59. In: W. Westheide \& C.O. Hermans (Eds). The ultrastructure of the Polychaeta. Microfauna Marina 4. Stuttgart, Fischer, 494p.

Stephen, A.C. \& S.J. Edmonds. 1972. The phyla Sipuncula and Echiura. London, The British Museum (Natural History) Publication 717, 528p.

Stephenson, J. 1930. The Oligochaeta. Oxford, Clarendon Press, XVI+978p.

Sтовсн, V. 1968. Zur vergleichenden Anatomie der segmentalen Muskelsysteme und zur Verwandtschaft der PolychaetenFamilien. Zeitschrift für Morphologie und Ökologie der Tiere 63: 251-342.

Strathmann, R.R. 1978. The evolution and loss of feeding larval stages of marine invertebrates. Evolution 32 (4): 894-906.

Thorson, G. 1946. Reproduction and larval development of Danish marine bottom invertebrates, with special reference to the planktonic larvae in the South (Öresund). Meddelelser fra Kommissionen Danmarks Fiskeri og Havesund Series Plankton 4: 1-523.

TIMм, T. 1981. Origin and evolution of aquatic Oligochaeta. Eesti Nsv Tead Akademi Toim Biologi 30 (3): 174-181.

ТІмм, T. 1987. Aquatic Oligochaeta of the northwestern part of the USSR. Talin, Zoological and Botanical Institutes, Akademia Nauk, 300p.

Trueman, E.R. 1975. The locomotion of soft-bodied animals. London, Arnold, 200p.

Turbeville, J.M. 1991. Nemertinea, p. 285-328. In: F.W. Harrison \& B.J. Bogitsch (Eds). Microscopic anatomy of invertebrates. New York, Wiley-Liss, vol. 3.

Valentine, J.W. 1989. Bilaterians of the Precambrian-Cambrian transition and the annelid-arthropod relationship. Proceedings of the Natural Academy of Science U.S.A. 86: 22722275.

Valentine, J. W. \& A. G. Collins, 2000. The significance of moulting in ecdysozoan evolution. Evolution \& Development 2 (3):152-156.

von Sternierg, R. 1997. Cladistics of the freshwater crab family Trichodactylidae (Crustacea: Decapoda): Appraising the 
reappraisal. Journal of Comparative Biology, Ribeirão Preto, 2 (1): 49-62.

WÄGELE, J.W. 1994. Review of methodological problems of 'computer cladistics' exemplified with a case study on isopod phylogeny (Crustacea: Isopoda). Zeitschrift für Zoologisch und Systematisch Evolutionsforschung 32: 81-107.

-1995. On the information content of characters in comparative morphology and molecular systematics. Journal of zoological Systematics and evolutionary Research 33: 42-47.

. 1996a. The theory and methodology of phylogenetic systematics is still evolving: A reply to Wilson. Vie et Milieu 46 (2): 183-184.

1996b. Identification of apomorphies and the role of groundpatterns in molecular systematics. Journal of zoological Systematics and evolutionary Research 34: 31-39.

- 1999. Major sources of errors in phylogenetic systematics. Zoologischer Anzeiger 238: 329-337.

Wägele, J.W.; T. Erikson; P. Lockhart \& B. Misof. 1999. The Ecdysozoa: Artifact or monophylum? Journal of zoological Systematics and evolutionary Research 37: 211-223.

Wägele, J.W. \& B. Misof. 2001. On quality of evidence in phylogeny reconstruction: a reply to Zrazvý's defense of 'Ecdysozoa' hypothesis. Journal of zoological Systematics and evolutionary Research 39: 165-176.

Wägele, J.W. \& R. Wetzel. 1994. Nucleic acid sequence data are not per se reliable for inference of phylogenies. Journal of Natural History 28: 749-761.

Walosser, D. \& K.J. Müller. 1994. Pentastomid parasites from the Lower Palaeozoic of Sweden. Transactions of the Royal Society of Edinburgh, Earth Sciences 85: 1-37.

WALOSSEK, D.; J.E. RePETSKI \& K.J. MÜLLER. 1994. An exceptionally preserved parasitic arthropod, Heymonsicambria taylori sp. nov. (Arthropoda incertae sedis: Pentastomida), from Cambrian-Ordovician bondary beds of Newfoundland, Canada. Canadian Journal of Earth Sciences 31 (11): 16641671.

Walton, L.B. 1927. The polychaete ancestry of the insects. American Naturalist 61: 226-250.

Watson Russell, C. 1989. Revision of Palmyra Savigny (Polychaea: Aphroditidae) and redescription of Palmyra aurifera. Beagle 6: 35-53.

Wевв, M. 1969. An evolutionary concept of some sessile and tubiculous animals. Sarsia 38: 1-8.

Weisblat, D.A.; C.J. Wedeen \& R. KostRiken. 1993. Evolutionary conservation of developmental mechanisms: comparisons of annelids and arthropods, p. 125-140. In: A.C. SPRADLING (Ed.). Evolutionary conservation of developmental mechanisms. New York, Wiley-Liss, 219p.
Westheide, W. 1986. The nephridia of the interstitial polychaete Hesionides arenaria and their phylogenetic significance (Polychaeta, Hesionidae). Zoomorphology 106: 35-43.

Westheide, W. 1997. The direction of evolution within the Polychaeta. Journal of Natural History 31: 1-15.

Westheide, W.; D. McHugh; G. Purschke \& G.W. Rouse. 1999. Systematization of the Annelida: different approaches. Hydrobiologia, 402: 291-307.

Weygoldt, P. 1986. Arthropod interelationships: The phylogenetic-systematic approach. Zeitschrift für Zoologische Systematic und Evolutionsforschung 24 (1): 19-35.

WILEY, E.O. 1981. Phylogenetics: the theory and practice of phylogenetic systematics. New York, Wiley and Sons, 439p.

WiLliamson, D.I. 1987. Incongrous larvae and the origin of some invertebrate life-histories. Progress in Oceanography 19: 87-116.

Willmer, P. 1990. Invertebrate relationships. Patterns in animal evolution. Cambridge, Cambridge University Press, 400p.

WiLson, D.P. 1932. On the mitraria larva of Owenia fusiformes Delle Chiaje. Philosophical Transaction of the royal Society, London, 221: 231-334.

WiLSON, W.H. 1991. Sexual reproductive modes in polychaetes: classification and diversity. Bulletin of Marine Science, Miami, 48 (2): 500-516.

Winnepenninckx, B.; T. Backeljau; Y. van Peer \& de R. Wachter. 1992. Structure of the small ribossomal subunit RNA of the pulmonate snail Limicolaria kambeul, and phylogenetic analysis of the Metazoa. FEBS Letters 309: 123-126.

WINNEPENNINCKX, B.; T. BACKELJAU \& R.M. KRISTENSEN. 1998. Relationships of the new phylum Cycliophora. Nature 393: 636-638.

WINNEPENNINCKX, B.; T. BACKELJAU; L.Y. MACKEY; J.M. BROOKS; R.DE WaChTER; S. KumAR \& J.R. Garey. 1995. 18S rRNA data indicate that Aschelminthes are polyphyletic in origin and consist of at least three distinct clades. Molecular Biology and Evolution 12 (6): 1132-1137.

Wolf, P.S. 1987. Aberrantidae: A new family of Polychaeta (Annelida). Bulletin of the Biological Society of Washington 7: 50-52.

Wray, G A. \& R.A. Raff. 1991. The evolution of developmental strategy in marine inverterbrates. Trends in Ecology and Evolution 6 (2): 45-50.

ZrzavÝ, J.; S. Minulka; P. Kepka; A. Bezdek \& D. Tiez. 1998. Phylogeny of Metazoa based on morphological and $18 \mathrm{~S}$ ribossomal DNA evidence. Cladistics 14 (3): 249-286.

ZRZAVÝ, J. \& P. STYS. 1995. Evolution of metamerism in Arthropoda: Development and morphological perspectives. The Quarterly Review of Biology 70 (3): 279-295.

Recebido em 12.VII.2002; aceito em 21.II.2003. 